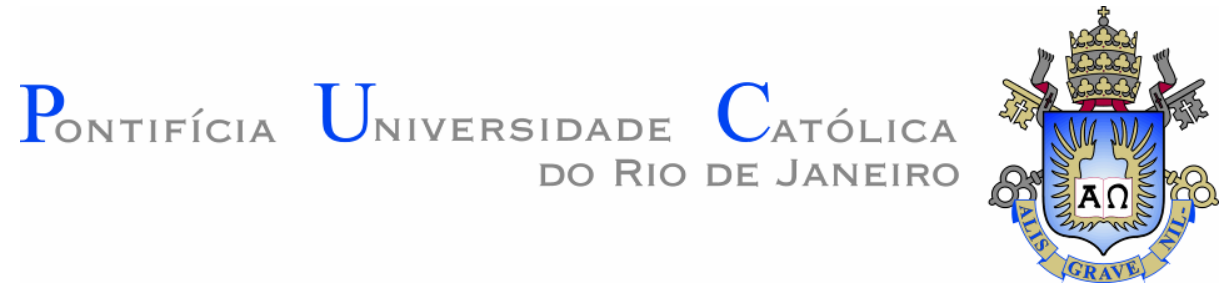

Maria Cristina Amorim Parga Martins

Fazendo a América -

Exílio e potência criativa através da escrita de ficção

Dissertação de Mestrado

Dissertação apresentada ao Programa de Pós-Graduação em Literatura, Cultura e Contemporaneidade da PUC-Rio como requisito parcial para obtenção do grau de Mestre em Letras/Literatura, Cultura e Contemporaneidade.

Orientador: Prof. Frederico Oliveira Coelho 


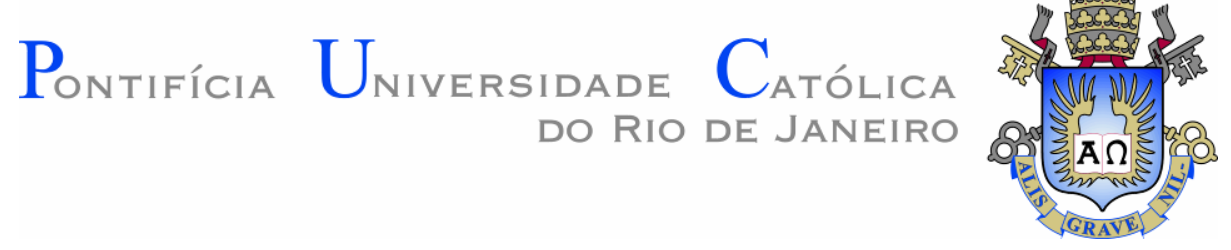

MARIA CRISTINA AMORIM PARGA MARTINS

\title{
Fazendo a América - exílio e potência criativa através da escrita de ficção
}

Dissertação apresentada como requisito parcial para obtenção do grau de Mestre pelo Programa de Pós-Graduação em Literatura, Cultura e Contemporaneidade do Departamento de Letras do Centro de Teologia e Ciências Humanas da PUC-Rio. Aprovada pela Comissão Examinadora abaixo assinada.

\author{
Prof. Frederico Oliveira Coelho \\ Orientador \\ Departamento de Letras - PUC-Rio
}

Profa. Lara Nogueira da Silva Leal

Departamento de Letras - PUC-Rio

Profa. Júlia Vasconcelos Studart

UNIRIO

Profa. Monah Winograd Coordenadora Setorial do Centro de Teologia e Ciências Humanas - PUC-Rio

Rio de Janeiro, 24 de abril de 2017. 
Todos os direitos reservados. É proibida a reprodução total ou parcial do trabalho sem autorização do autor, do orientador e da universidade.

Maria Cristina Amorim Parga Martins

Graduou-se em Ciências da Comunicação na Faculdade de Ciências Sociais e Humanas da Universidade Nova de Lisboa (Portugal); possui especialização e História Contemporânea pela Faculdade de Ciências Sociais e Humanas da Universidade Nova de Lisboa (Portugal) e pósgraduação em Literatura Arte e Pensamento Contemporâneo pela Pucrio. Sua área de interesses é ligada a temática do exílio, migrações autoficção e da criação literária. É autora dos livros Furta-cores (2012, contos/7Letras) e Qualquer areia é terra firme (2015, romance 7Letras) Participou de diversos congressos científicos, além de atuar profissionalmente no mercado editorial.

Ficha Catalográfica

Martins, Maria Cristina Amorim Parga

Fazendo a América - exílio e potência criativa através da escrita de ficção / Maria Cristina Amorim Parga Martins ; orientador: Frederico Oliveira Coelho. -2017. $137 \mathrm{f} . ; 30 \mathrm{~cm}$

Dissertação (mestrado)-Pontifícia Universidade Católica do Rio de Janeiro, Departamento de Letras, 2017. Inclui bibliografia

1. Letras - Teses. 2. Exílio. 3. Literatura de exílio. 4. Imigração. 5. Autoficção. 6. Criação artística. I. Coelho, Frederico Oliveira. II. Pontifícia Universidade Católica do Rio de Janeiro. Departamento de Letras. III. Título.

CDD: 800 
Para meus pais, Sílvia e Américo, e meu irmão Pedro.

Para Eduardo, Odete e a pequena Talita. 


\section{Agradecimentos}

Agradeço aos meus pais, Silvia Parga e Américo Martins, pela confiança e suporte emocional e à minha avó Margarida, que partilhou comigo sua história. A Eduardo Trezena, por significar pátria em qualquer lugar do mundo. Agradeço também à querida amiga Kátia Zanon, pelo incentivo ao longo desta caminhada, e a Antonia Costa, Antonia de Thuin e Maíra Fernandes de Melo pela interlocução, presença, apoio e carinho. Aproveito para dizer o meu obrigada ao meu orientador Frederico Coelho, aos membros da banca pelo interesse no projeto, ao CNPQ e aos queridos professores do Departamento de Letras da PUC-Rio. 


\section{Resumo}

Martins, Maria Cristina Amorim Parga; Coelho, Frederico Oliveira. Fazendo a América - exílio e potência criativa através da escrita de ficção. Rio de Janeiro, 2017. 137p. Dissertação de Mestrado Departamento de Letras. Pontifícia Universidade Católica do Rio de Janeiro.

A pesquisa de mestrado intitulada Fazendo a América investiga, de forma teórica e ficcional, o potencial criativo que o exílio enquanto instância subjetiva não apenas geográfica - desperta no indivíduo. A dissertação entretece discussão teórica à escrita de autoficção, com a apresentação de uma novela sobre uma família com quatro gerações de imigrantes e suas histórias. $\mathrm{O}$ formato ficcional permite pensar o exílio, sua potência e seus desdobramentos através da própria escrita, e explorar a sensação de identidade fragmentária e de alteridade geradas tanto pelo exílio geográfico como por diferentes exílios interiores e sociais patentes na contemporaneidade - entre eles o do escritor, que trafega entre o mundo real e o do papel. Partindo da visão flusseriana do exilado "não como vítima, mas como vanguarda", Fazendo a América joga luz sobre a ideia de "libertação vertiginosa" (FLUSSER, 2007) que a "força desestabilizadora" (SAID, 2006) do exílio carrega, e conclui que as fendas subjetivas abertas pelo exílio são também espaços de potência e fertilidade para a criação artística.

\section{Palavras-chave}

Exílio; literatura de exílio; imigração; autoficção; criação artística. 


\section{Abstract}

Martins, Maria Cristina Amorim Parga; Coelho, Frederico Oliveira (Advisor). Making America - exile and creative power through fiction writing. Rio de Janeiro, 2017. 137p. Dissertação de Mestrado Departamento de Letras. Pontifícia Universidade Católica do Rio de Janeiro.

The master's research entitled Making America investigates, in a theoretical and fictional way, the creative potential that the exile as a subjective instance - not just as a geographic one - awakens in the individual. The dissertation intertwines theoretical discussion with the writing of self-fiction, with the presentation of a novel about a family with four generations of immigrants and their stories. The fictional format allows one to think of exile, its power and its unfolding through writing itself, and to explore the sense of fragmentary identity and alterity generated both by geographical exile and by different inner and social exiles evident in contemporaneity - among them that of the writer, who travels between the real and the paper worlds. Making America emphasizes the idea of "vertiginous liberation" (FLUSSER, 2007) that the "destabilizing force" (SAID, 2006) of the exile carries with it, and concludes that the subjective gaps opened by exile are also spaces of power and fertility for artistic creation.

\section{Keywords}

Exile; Exile Literature; Immigration; self-fiction; Artistic creation. 


\section{Sumário}

1. Introdução 11

1.1. Como se $f a z$ um continente, uma novela, uma pesquisa?

1.2. A diferença fala - importância da alteridade

e possibilidades de representação

1.3. Multiculturalismo e o Outro no espaço literário brasileiro

1.4. Entre-lugar e terceiro espaço

1.5. Flusser - o exílio como "vertigem da libertação"

1.6. Said - O escritor, o intelectual e o exilado

1.7. Metodologia - Ou, por que uma novela?

1.8. A literatura como mundo

2. Fazendo a América 
Uma divindade maior estava à sua volta: a América, no auge do seu poder híbrido, onívoro. A América para onde tinha vindo para se apagar. Para se libertar de ligações e também da raiva, do medo e da dor. Engula-me, orou em silêncio o professor Solanka. Engula-me, América, e me dê paz.

Rushdie, 2013 
I belong here. I was born here. The palms sift their fingers and the men shove by in shirts, shaving in underwear shorts. They curse and scratch the wet hair in their armpits, and spit. Whores spread their delicate little germs or, indifferently, don't, smiling. The waves wash in, warm and salty, leaving your eyebrows white and the edge of your cheekbone. Your ear aches. You are lonely. On the underside of a satin leaf, hot with shade, a scorpion sleeps. And one Sunday I will be shot brushing my teeth. I am a native of this island

\section{Frank O’Hara}




\section{Introdução}

“O exílio é a vida levada fora da ordem habitual. É nômade, descentrada, contrapontística, mas assim que nos acostumamos a ela, sua força desestabilizadora entra em erupção novamente", diz Said (2006, p. 60); “é uma fratura incurável entre um ser humano e um lugar natal, entre o eu e seu verdadeiro lar", completa. Numa contemporaneidade marcada pelos deslocamentos em massa, identidades fragmentadas e dissolução de fronteiras, o exílio é uma condição vivenciada em diversos graus e tonalidades pelo indivíduo; além da ruptura física com a pátria-mãe vivida por refugiados e imigrantes, há outras do foro subjetivo, consequências do questionamento de ideias de nação e identidade, entre outros "fundamentos" que se apresentam como instáveis.

Pensando o exílio enquanto instância - em suas diferentes formas que não só aquelas ligadas ao deslocamento - esta dissertação irá explorar o potencial criativo que a sua "força desestabilizadora", conforme nos diz Said, desperta.

Diante de um rico panorama teórico, optei por pensar o tema não apenas através da leitura de textos críticos, mas pela escrita de uma narrativa de ficção. O resultado é Fazendo a América, uma novela sobre imigração e outros exílios; uma dissertação bordada no tecido da ficção.

A narrativa-dissertação se propõe a pensar vários tipos de exílio, os seus desdobramentos e o ato criativo e transformador que a ruptura com uma pátriamãe pode originar no indivíduo, no seu pensamento, nas suas obras.

Para alguns críticos, o formato ficcional parte da ideia de que o pensamento também é concebido, gestado e apresentado ao pesquisador pelo próprio ato da escrita. Como nos diz Barthes, em Aula (1980), o autor literário enfrenta um complexo processo ao tecer o seu ofício - complexo que envolve todo esforço, o sofrimento e o trabalho árduo que escrever exige. Longe de ser um processo linear, escrever exige tempo, inúmeras releituras, reescritas, paciência até que se consiga registrar em palavras um pensamento, uma imagem.

A leitura de Barthes, também ele um escritor de diários, fortalece a ideia de escrita como um hábito a ser alcançado e não como um dom sobrenatural; hábito que requer uma formação, que depende de um conhecimento profundo 
sobre os labirintos do próprio pensamento, sobre as formas de elaborar e enfrentar o pensamento, e sobre como este adquire novas formas através da escrita.

A literatura assume muitos saberes. Num romance como Robinson Crusoé, há um saber histórico, geográfico, social (colonial), técnico, botânico, antropológico (Robinson passa da natureza à cultura). Se, por não sei que excesso de socialismo ou de barbárie, todas as nossas disciplinas devessem ser expulsas do ensino, exceto uma, é a disciplina literária que deveria ser salva, pois todas as ciências estão presentes no monumento literário (...). A literatura faz girar os saberes, não fixa, não fetichiza nenhum deles; ela lhes dá um lugar indireto, e esse indireto é precioso. Por um lado, ele permite designar saberes possíveis - insuspeitos, irrealizados: a literatura trabalha nos interstícios da ciência: está sempre atrasada ou adiantada com relação a esta (...). A ciência é grosseira, a vida é sutil, e é para corrigir essa distância que a literatura nos importa. Por outro lado, o saber que ela mobiliza nunca é inteiro nem derradeiro; a literatura não diz que sabe alguma coisa, mas que sabe de alguma coisa; ou melhor: que ela sabe algo das coisas. (BARTHES, 1980, p. 18-19)

Se escrever é assumir muitos saberes, este ofício implica num processo duplo, em que o próprio pensamento vai se revelando e modificando no ritmo do embate entre escritor, pena e papel. De acordo com a ideia de que ficção é também produção de pensamento, nesta dissertação-novela apresento, além da escrita em si, os bastidores do ato de criar esta narrativa a seguir.

Ao analisar a Recherche Proustiana, Barthes aponta para o desejo de escrever - o "querer-escrever" como objeto da narrativa do autor francês, e não a autobiografia.

(...) na Recherche há certamente "narrativa" (não é um ensaio), mas essa narrativa não é a de uma vida que o Narrador tomasse no nascimento e conduzisse de ano em ano até o momento em que toma da pena para narrá-la. O que Proust conta, o que coloca em narrativa (...), não é a sua vida, é seu desejo de escrever (...). (BARTHES, 2004, p. 355)

No incontornável A preparação do romance I, Barthes se aprofunda nesta designação do objeto da Recherche, que serve de paradigma para novas práticas de escrita, nas quais o teórico ou pesquisador se instala dentro do romance. "É talvez a própria definição tópica da escritura (da literatura) oposta à 
Ciência: ordem do saber, na qual o produto não é distinto da produção, e a prática (não é distinta) da pulsão (nisso pertencente a uma erótica)" (BARTHES, 2005, p. $17)$.

Essa pulsão do querer-escrever traduz-se, para Barthes, numa mudança de posição de autor, pesquisador e teórico:

Coloco-me realmente na posição de quem faz alguma coisa, e não mais de quem fala sobre alguma coisa: não estudo um produto, endosso uma produção; elimino o discurso sobre o discurso; o mundo já não vem a mim sob a forma de um objeto, mas sob a de uma escritura, quer dizer, de uma prática: passo para o outro tipo de saber (o do Amador), e é nisso que sou metódico. (BARTHES, 2004, p. 363)

A partir de Barthes, é possível reforçar a ideia de que o objeto da presente pesquisa não é apenas o tema do exílio, mas múltiplos afetos que incluem um "querer-escrever" e querer instalar o pensamento dentro da narrativa.

Assim, o projeto literário desenvolvido nesta dissertação é essencialmente de gênero híbrido, um experimento em aberto entre a narrativa ficcional, o ensaio e a pesquisa, exibindo intencionalmente traços, vestígios e marcas bibliográficas, mostrando o caminho da formação do pensamento pelo escrever, e num movimento duplo, experimentando o escrever ficcional a partir da pesquisa.

\subsection{Como se faz um continente, uma novela, uma pesquisa?}

O título Fazendo a América evoca o romance não acabado de Kafka, autor que, sob diversos aspectos, trabalha exílios subjetivos em sua obra. A referência e homenagem termina aí - a novela se baseia nos dados biográficos da minha família paterna, fundindo e ressignificando as vivências de quatro gerações. Reunindo os relatos da avó, que troca Portugal pelo Brasil, e do pai, que chega ao Rio de Janeiro criança, às memórias dos 10 anos em que vivi em Lisboa, a história passa pelo nascimento em Portugal da sobrinha, que, 70 anos depois da bisavó, é imigrante também, fechando - ou não - o ciclo.

A escrita de ficção, aqui, é movida tanto pelo questionamento crítico sobre o tema do exílio como, conforme já referido, por dimensões múltiplas do 
afeto, que envolvem o "querer-escrever", o desejo de recordar, a vontade de conjurar outras vozes e de não deixar morrer a voz daqueles que (se) partem. As histórias surgem por memórias alojadas em fendas desconhecidas, misturando sonhos, sentidos e conteúdos emocionais que contaminaram quatro gerações.

Se nesta novela o exílio - e a doença - é um fado que contamina cada geração, ele o faz sempre de uma nova forma inusitada, se desdobrando em nuances, ganhando novos significados e sentidos para cada um dos que o têm como herança.

Explorar este tema através da ficção permite uma abordagem dupla; por um lado, é possível articular, na própria narrativa, uma filosofia positiva do exílio como a de Vilém Flusser e o pensamento sobre deslocamento e alteridade de Stuart Hall, Homi Bhabha e Edward Said, entre outros autores, que enriquecem e ampliam a discussão. Por outro lado, permite que as vozes da bibliografia coexistam sem se sobreporem àquelas dos exilados, que mantêm seu protagonismo, deslocando-se com suas histórias e memórias através das páginas.

A bibliografia sobre o tema do exílio é vasta; porém, grande parte dos textos com os quais me deparei incide com insistência sobre o aspecto traumático presente no ato de exilar-se ou ser exilado, não se detendo tanto sobre o seu potencial de criação e transformação que este representa para o indivíduo. Esta bibliografia inclui autores como Kristeva - que se aprofundou sobre a condição do estrangeiro e do Outro; Cathy Varuth, que relaciona o conceito freudiano de trauma, incapacidade de representação e suas implicações na narrativa; Walter Benjamin, que, entre muitas questões, aponta a situação do narrador exilado, errante e colecionador de destroços; Shoshana Felman, que se lança sobre a crise do testemunho após o Holocausto.

É compreensível o protagonismo destes textos que pensam o tema a partir das catástrofes do século XX - compreensível e essencial no contexto pósHolocausto, afastando o perigo de um relativismo pós-moderno, e contribuindo para uma ética da história e da memória.

Tendo esse aspecto em conta, e sem pretender de maneira alguma desprezar essa bagagem, optei por expandir, ao longo destes meses, a bibliografia para que esta abarcasse autores que trabalham com o pensamento diaspórico; e, de forma geral, autores que exploram, seja na sua ficção ou teoria, o quanto de 
violência - e de criação, quebra de estruturas e efervescência - o imigrante e o estrangeiro transportam em sua bagagem. Pensadores como Rushdie, Appaduraih, Homi Bhabha, Said; escritores como a nigeriana Chimamanda Adichie, a poeta argentina Tamara Kamenszain, a poeta afroamericana Nayyirah Waheed, o bósnio Aleksander Hemon, o alemão W. G. Sebald, o chileno Alejandro Zambra, o polonês Grombrowsky, entre outros.

Nos escritos de Homi Bhabha e Edward Said e na filosofia do exílio de Vilém Flusser encontrei o suporte teórico para aquilo que esta pesquisa, produzida a partir do processo de escrita de ficção, trouxe à tona ao longo do mestrado - a ideia de que a migração, além de ser um sofrimento, é "uma atividade criativa", como defende Flusser (2007, p. 296), na autobiografia filosófica Bodenlos, traduzida pela editora Annablume em 2007. No livro, Flusser reflete sobre a amplitude de pensamento que o migrante ganha, justamente por ser (ou sentir-se) deslocado. Em vez de pessoas dignas de pena, estes deslocados seriam "modelos" para o futuro: "Nós, os incontáveis milhões de migrantes (sejamos trabalhadores estrangeiros, exilados, fugitivos ou intelectuais andando de seminário em seminário), nos reconhecemos não como excluídos [Aussenseiters], mas antes como vanguardas [Vorposten] do futuro" (FLUSSER, 2007, p. 249).

Assim, em Fazendo a América, procuro transpor para a escrita a sensação de identidade fragmentária e de alteridade vivida pelo exilado, pelo imigrante e, por fim, pelo escritor, que trafega entre o real e a ficção e se move no terreno estrangeiro do papel. Pois, como explica Daniela Birman,

Não é preciso, portanto, ser um exilado "real" para se aproximar dessa temática. Para Blanchot, com efeito, o ato de escrever transforma o autor num estrangeiro, figura sem identidade que está em busca de um fora, uma ausência que jamais pode ser materializada, transformada em presença. A linguagem nesse caso é da ordem da dissimulação, pois não existe de forma positiva. Ao escrever, o autor vivencia a solidão essencial e a irrealidade: dele mesmo, do outro, do mundo e da linguagem. (BIRMAN, 2003, p. 3)

E ainda:

A busca do fora descrita por Blanchot, com efeito, só se torna possível com a verticalização da linguagem. Apenas depois que a linguagem deixou de se basear em figuras absolutas - sejam elas 
Deus, a Razão ou a Verdade - é que ela se dobrou sobre si mesma e passou a ser atravessada pela busca de seu próprio limite. E o escritor pôde, dessa forma, ser guiado pela procura do vazio da linguagem, do fora, transformando-se num estrangeiro e numa figura atravessada pela certeza de sua própria finitude. (BIRMAN, 2003, p. 3)

O projeto se constitui em duas fases (ou camadas) de escrita ficcional, pontuadas por parágrafos em que a teoria crítica será discutida. A primeira camada consiste na escrita de um romance sobre imigração e exílio, baseado na história de uma família. Num movimento paralelo, a narrativa investiga questões relacionadas a diferentes instâncias de exílios na nossa sociedade a partir de personagens ficcionais que chamo de marcadores, que se deslocam de uma forma independente através dos parágrafos da história. A princípio estes personagens parecem acessórios, sem um papel essencial na trama, surgindo e ressurgindo como um ruído insistente ao longo das páginas, esbarrando brevemente com personagens principais, reaparecendo em momentos inesperados. $\mathrm{O}$ perambular desses personagens ao longo da história revela, nesse movimento exterior, à margem, as diversas formas como exilados de diferentes instâncias costuram a sua própria história, com toda a potência transformadora e a liberdade que deixar para trás um país, uma posição social, uma teia de afetos lhes confere.

Ao unir memórias próprias, de familiares e de outros imigrantes, ocupando espaços inusitados com personagens aparentemente deslocados da narrativa, a dissertação se propôs a pensar, através da ficção, o exílio enquanto instância subjetiva, não dependente de um deslocamento físico, explorando a ideia de que há diferentes exílios interiores e sociais patentes na contemporaneidade. $\mathrm{E}$ a jogar luz sobre o potencial criativo que o exílio e sua "força desestabilizadora", conforme nos diz Said (2006, p. 60), ou a "libertação vertiginosa" como nos diz Flusser (2007, p. 39), desperta; como, para além do trauma, é possível tornar essa fenda num espaço fértil para a criação artística.

O objetivo dessa dissertação é, portanto, explorar e pensar, através da escrita de ficção, o exílio como uma força criativa. O objeto de estudo foi ganhando novas formas e contornos já nas primeiras leituras, que questionavam a definição de exílio como resultante de um deslocamento geográfico. Uma importante leitura foi o "Tratado de Nomadologia" (1997), de Deleuze e Guattari, 
no qual os autores exploram a correlação entre interioridade e exterioridade, e discutem o conceito foucaultiano de "pensamento do fora" enquanto uma máquina de guerra que se subtrai à soberania, escapa às engrenagens do poder - e ameaça modelos e formas rígidas, ou seja, a normatividade. ${ }^{1}$ A partir do texto, presente em Mil Platôs, foi possível pensar o exílio como uma instância, quando o sujeito ocupa um lugar - geográfico ou subjetivo - à margem, exterior à norma - lugar que, apesar de vulnerável, permite esse "pensamento do fora" que "escapa às engrenagens do poder"; um 'não pertencimento"” (DELEUZE; GUATTARI, 1997, p. 46). Um lugar externo que permita transformar a posição vulnerável do desamparo em liberdade, em linhas de fuga por onde circulam livremente desejos, intensidades - que reverberam em versos, performances, imagens, traços, ou na construção da própria narrativa de vida.

Embora parta da ideia de exílio como instância e força criativa, ao longo da narrativa ficcional, o narrador/pesquisador sublinha que o exílio pode constituir um trauma, uma ruptura na identidade, conforme autores como Kristeva (2004), Felman (1991) e caruth (1995) nos mostraram. Porém, perante fatos, conversas e - principalmente - leituras, conclui que dessa fissura identitária e da fricção entre novas culturas, pode surgir não só melancolia e dor, mas pulsão criativa. Seja para a produção artística e cultural, seja para a construção de uma nova narrativa de vida.

Conforme já referido, além da história familiar da narradora, Fazendo a América costura no tecido narrativo as figuras de "personagens marcadores", que, no seu perambular ao longo das histórias, revelam diferentes instâncias de exílio. Atravessando parágrafos, páginas e furando o fio condutor da história central, estes personagens foram desenhados como dispositivos para se pensar sobre, dentro do espaço da ficção, o exílio e seus desdobramentos.

Movendo-se a um ritmo próprio pelas páginas, criando atalhos, rotas de fugas, seus esbarrões com os personagens da narrativa principal pretendem confrontar o leitor, simulando o movimento à margem do imigrante-exiladocontemporâneo perante as personagens centrais, o nativo, a sociedade, e quem Mil Platôs I de que o pensamento, frente ao Estado que representaria a centralização máxima do poder e da norma, possui duas possibilidades: ou está de acordo com o modelo fixado, ou seja, abrigado no interior da normatividade; ou é fugidio, insinuante, desconcertante e, sem modelo e sem fixidez, constitui uma ameaça à norma. (DELEUZE; GUATTARI. 1995, p. 46) 
quer que tenha suas raízes radicadas seja num país, numa ideia de pertença, numa narrativa. Seu movimento ao longo das páginas contribui para trazer à tona questões como: a estigmatização do estrangeiro como Outro, a ancoragem da nossa identidade nas regras de uma Pátria ou das normas sociais; a rejeição a quem não as domina com naturalidade; os dispositivos para tornar esse Outro invisível.

\subsection{A diferença fala - importância da alteridade e possibilidades de representação}

Dentre vários nomes presentes na bibliografia, alguns intelectuais, como Stuart Hall, Homi Bhabha, Edward Said e o polonês radicado no Brasil, Vilém Flusser, transformaram o exílio vivido pessoalmente em um tema que circunda com vigor suas obras.

Stuart Hall nasceu na Jamaica; Homi Bhabha na Índia. Migrantes de excolônias britânicas que construíram suas carreiras em grandes instituições acadêmicas europeias e norte-americanas, ambos viveram as experiências do deslocamento, não-reconhecimento e não-pertencimento. $\mathrm{O}$ mesmo se pode dizer de Edward Said, que, nascido em Jerusalém, crescendo entre esta cidade e o Cairo, e migrando para os EUA, onde desenvolveu sua vida acadêmica, também viveu na pele as ambivalências da perda de um lar, da separação dos entes queridos, da liberdade de pensar fora da mentalidade daqueles ligados à identidade nacional. Como Vilém Flusser, parece que a vivência da migração, da "perda" da pátria-mãe e do isolamento alavancou o desejo de pesquisa, escrita, reflexão. Todos estes pesquisadores foram essenciais na escrita de Fazendo a América não só como bagagem teórica, mas como companheiros de bordo numa narrativa que almeja pensar e fazer pensar sobre o exílio, a migração, a alteridade e a nossa relação com o Outro.

De acordo com Stuart Hall, a alteridade existe em diversas dimensões de diferença, que podem ser raciais, de gênero, de classe social ou de deficiências. Para explicar o fascínio da representação popular do Outro e sua transformação em estereótipo, Hall explora profundamente os conceitos de "representação" e "diferença". Primeiro, questiona se é possível uma "efetiva política da representação" - tomando a imagem como eixo, analisa o termo de representação 
como prática e conceito. E conclui que essa representação do Outro é algo complexo, que envolve atitudes e emoções e mobiliza medos e ansiedades nos espectadores.

A diferença "fala", afirma Hall. Como essa fala é interpretada é uma constante preocupação na representação de migrantes, minorias raciais ou pessoas diferentes da maioria. Para analisar a fundo os conceitos de alteridade e representação - e seus problemas -, o autor explora o conceito de diferença em quatro ramos diversos de análise (não excludentes): o linguístico, o social, o cultural e o psicanalítico.

No primeiro caminho, Hall segue a semiótica de Saussure, segundo a qual sem diferença não há significado; portanto, a subjetividade de uma maioria é definida pelo contraste com a alteridade. Porém, se o significado depende da diferença de opostos, essa oposição costuma ser binária e, portanto, reducionista e simplificadora.

Pessoas diferentes da maioria - "eles" em vez de "nós"- são frequentemente expostas a essa forma binária de representação (...) polarizada em extremos como bom-ruim, civilizado-primitivo, feio-excessivamente atraente, repulsivo porque estranho, e atraente porque exótico. (HALL, 1997, p. 229)

Outro perigo dessa oposição binária é apontado por Hall a partir de Derrida: "um dos polos do binário é normalmente o dominante, aquele que inclui o Outro no seu campo de operações. Há sempre uma relação de poder entre os polos de uma operação binária” (DERRIDA apud HALL, 1997, p. 235). Ou seja, a maioria detém o poder de como representar o Outro, que é catalogado, categorizado e compreendido, para deixar de ser fonte de perturbação.

Bakhtin apresenta sua contribuição: "Precisamos da 'diferença' porque só podemos construir significados através do diálogo com o Outro" (HALL, 1997, p. 235).

A via antropológica também oferece um caminho para se entender a importância do "Outro". Hall cita Mary Douglas, que, seguindo o caminho iniciado por Durkheim e Lévi-Strauss, defende que os grupos sociais impõem o significado ao mundo organizando e ordenando tudo em sistemas classificatórios. Douglas alerta, no entanto, que 
o que realmente perturba a ordem cultural é o fato de algumas coisas se encaixarem em categorias erradas ou falharem em se enquadrar em qualquer categoria.(...) O que perturba a cultura é 'matéria fora de lugar' - a quebra de regras e códigos não escritos, mas implícitos. (DOUGLAS apud HALL, 1997, p. 236)

Douglas explica que o primeiro movimento da maioria hegemônica "Nós" - é tentar esconder o "Outro" debaixo do tapete, descartá-lo, para restaurar a ordem "natural". Kristeva completa: "O movimento de muitas culturas em direção ao afastamento ou remoção de estrangeiros, intrusos, aliens e 'outros' faz parte do mesmo processo de purificação" (KRISTEVA apud HALL, 1997, p. 236).

\subsection{Multiculturalismo e o Outro no espaço literário brasileiro}

Os aliens referidos por Kristeva são, no âmbito desta dissertação, não apenas os estrangeiros, mas diversos "Outros" que foram empurrados para uma posição de alienação, invisibilidade ou exclusão pela sociedade. No Brasil, por exemplo, é notório como a intelectualidade brasileira silenciou as vozes periféricas, sejam de migrantes, índios, mulheres, negros e pobres, cuidando de representá-las a seu modo. Quem está fora do circuito do poder vira objeto, sendo tratado, "traduzido", categorizado, estereotipado para ser "compreendido" - ou, seguindo o pensamento de Douglas, para não "perturbar a ordem". Sobre este tema, Silviano Santiago, em Cosmopolitismo do pobre, explica que "apesar de pregar a convivência pacífica entre os vários grupos étnicos e sociais que entraram em combustão em cada melting pot", a ação multicultural nesse caso é "obra de homens brancos para que todos, indistintamente, sejam disciplinarmente europeizados como eles" (SANTIAGO, 2004, p. 9).

Ao analisar a autobiografia de Joaquim Nabuco, Silviano Santiago destaca que este intelectual, já no início do século XX "reflete sobre o modo como o brasileiro, caso perca a menoridade política, pode transformar-se em sujeito da história nacional, embora ainda fique sujeito à formação ministrada pela Europa moderna e à dependência da cultura ocidental” (SANTIAGO, 2011, p. 2). 
A reflexão de Silvano Santiago a respeito do cenário literário burguêselitista que dominou o nosso país até o início dos anos 1990 dialoga com as preocupações da autora indiana Gayatri Spivak, expostas em 1976 no prefácio da tradução para o inglês de Gramatologia, de Derrida. No texto, a autora alerta para a necessidade de desafiar os discursos hegemônicos e também as nossas próprias crenças como leitores e produtores de saber e conhecimento, tentando produzir um discurso crítico sobre sociedade e cultura que busque influenciar e alterar a forma como apreendemos o mundo contemporâneo.

Transitando por várias áreas de conhecimento, sua crítica, de base marxista, pós-estruturalista e desconstrucionista, se alia a posturas teóricas que abordam o pós-colonialismo, o feminismo contemporâneo, e as teorias do multiculturalismo e da globalização. Vinculada a um grupo de "estudos subalternos", liderado por Gramsci, que se detém nas classes subalternas como aquelas alijadas do poder, a autora sustenta uma postura crítica, julgando necessário refletir sobre uma questão fulcral nos estudos pós-coloniais: o subalterno, como tal, pode, de fato, falar? Ao mesmo tempo, Spivak rejeita o que considera uma apropriação errônea do termo subalterno, que não pode se referir a qualquer sujeito marginalizado e sim àquele cuja voz não pode ser ouvida. $\mathrm{Ou}$ seja, "as camadas mais baixas da sociedade constituídas pelos modos específicos de exclusão dos mercados, da representação política e legal, e da possibilidade de se tornarem membros plenos no estrato social dominante" (SPIVAK, 2014, p. 14).

Em Pode o subalterno falar?, Spivak questiona a postura do intelectual pós-colonial, afirmando que nenhum ato de resistência pode ocorrer em nome do subalterno sem que esse ato esteja enraizado no discurso hegemônico. Indo mais longe, a autora revela o lugar incômodo e a cumplicidade do intelectual que julga poder falar pelo outro e, por meio dele, construir um discurso de resistência.

"Agir dessa forma", Spivak argumenta, "é reproduzir as estruturas de poder e opressão, mantendo o subalterno silenciado, sem lhe oferecer uma posição, um espaço de onde possa falar e, principalmente, no qual possa ser ouvido" (SPIVAK, 2014, p. 14). A autora chama a atenção para o perigo do subalterno se constituir apenas um objeto de conhecimento por parte de intelectuais que querem falar pelo outro, e conclui que o espaço de interação e 
diálogo não se concretiza para o sujeito subalterno que, desinvestido de qualquer forma de agenciamento, “de fato não pode falar" (SPIVAK, 2014, p. 14).

Derrida aqui faz escolhas nietzscheanas, filosóficas e psicanalíticas, mais do que especificamente políticas, para propor uma crítica ao etnocentrismo europeu na constituição do sujeito do Outro. Como uma intelectual pós-colonial, não tenho problemas com o fato de ele não me dirigir (como os europeus inevitavelmente parecem fazer) ao caminho específico que tal crítica torna necessária. Considero mais importante que, como filósofo europeu, ele articula a tendência do Sujeito europeu de constituir o Outro como sendo marginal ao etnocentrismo e localize esse como sendo o problema de todos os esforços logocêntricos. (SPIVAK, 2014, p. 108)

E completa:

Não um problema geral, mas um problema europeu. É no contexto desse etnocentrismo que ele tenta tão desesperadamente degradar o Sujeito do pensamento ou conhecimento para dizer que 'o pensamento é (...) a parte em branco do texto' (OG, p. 93); aquilo que é pensado, mesmo em branco, ainda está no texto e deve ser confiado ao Outro da história. Esse espaço em branco inacessível, circunscrito por um texto interpretável, é o que a crítica póscolonial do imperialismo gostaria de ver desenvolvida, no espaço europeu, como o lugar da produção da teoria. (...) Tornar o pensamento ou o sujeito pensante transparente ou invisível parece, por contraste, ocultar o reconhecimento implacável do Outro por assimilação. (SPIVAK, 2014, p. 108)

O problema europeu apontado por Spivak vai se espelhar nas culturas pós-coloniais de terceiro mundo, como o Brasil, que mantém uma dependência cultural europeia e, por conseguinte, um reconhecimento desse Outro periférico por assimilação. Santiago cita os conceitos de etnocentrismo e de aculturação como base para esse tipo de multiculturalismo; aculturação aqui como "o conjunto de fenômenos que resultam de um contato contínuo e direto entre grupos de indivíduos de culturas diferentes e que acarretam transformações dos modelos culturais iniciais de um dos dois grupos" (REDFIELD; LINTON; HERSKOVITS apud SANTIAGO, 2004, p. 55).

"No Brasil, como se sabe, a visada multiculturalista foi fortalecida pela ideologia da cordialidade" continua Santiago (2004, p. 55), citando alguns exemplos clássicos na nossa literatura, como Iracema (1865), de José de Alencar, 
O cortiço (1888), de Aluísio Azevedo e Gabriela, cravo e canela (1985), de Jorge

Amado.

Por esse multiculturalismo fala a voz impessoal e sexuada do estado-nação que, retrospectivamente tinha sido constituído no interior do melting-pot. Neste, sob o império das elites governamentais e empresariais e das leis do país, várias e diferentes etnias, várias e diferentes culturas se cruzaram patriarcal e fraternalmente (...) Misturaram-se para constituir uma outra e original cultura nacional, soberana, cujos dominantes, no caso brasileiro, foram o extermínio dos índios, o modelo escravocrata de colonização, o silêncio das mulheres e das minorias sexuais. (...) A construção do Estado pelas regras desse multiculturalismo teve como visada prioridade o engrandecimento do estado-nação pela perda da memória individual do marginalizado e em favor da artificialidade da memória coletiva. (SANTIAGO, 2004, p. 56-58)

Ao não existir como sujeitos discursivos, a periferia não tem representação própria, não consegue reivindicar o que lhe faz falta, nem ser ouvida numa posição de simetria com a maioria dentro da sociedade.

Ao longo da pesquisa (re)encontrei grupos de autores que me impactaram com um exílio devido à exterioridade, conforme definido por Foucault, Deleuze e Guattari, um exílio que ultrapassa a instância subjetiva - reflete também questões históricas e sociais. Fossem periféricos, "marginais", migrantes, queers ou os subalternos de Spivak, esses autores partilham uma posição de isolamento e singularidade por ocuparem um lugar exterior face à normatividade que os rodeia. A partir da noção de exterioridade, do desamparo freudiano e de linhas de fuga, de Deleuze e Guattari, foi possível pensar a literatura, as artes visuais e outras manifestações artísticas que emergem a partir de um lugar ou modo de estar exterior à segurança e amarras da normatividade. Escritas qualificadas como "Literatura menor" por Deleuze e Guattari, que pertencem “à língua que uma minoria $^{2}$ constrói numa língua maior” (DELEUZE, 2002, p. 38),, e que se distinguem pelas suas condições revolucionárias no seio daquela a que se chama grande (ou estabelecida). O tema é claro, merece um estudo amplo, que pretendo

2 Minoria, aqui, não é definida pela quantidade numérica, mas "pelo ajustamento, pela distância em relação a uma dada característica da axiomática dominante. (...) Contrariamente, a maioria é sempre assimilada à categoria da 'representação', ou seja, está integrada numa generalidade normalizadora e identificatória. Os seus elementos estão incluídos num conjunto global e abstracto que os divide em oposições binárias, determinando uma exclusão entre o que é ou não conforme ao maioritário enquanto norma.” (GODINHO apud DELEUZE, 2002, p. 15) 
desenvolver futuramente em um projeto de doutorado. Para a discussão aqui presente, gostaria de correlacionar a ideia de pensamento exterior deleuziano e a chamada "Literatura menor" com uma ideia de exílio que compreende não apenas o migrante geográfico, mas o sujeito periférico, arrastado para o exterior de um núcleo de poder, como o escritor/artista marginal brasileiro. Aquele que, até os anos 1990, segundo Paulo Tonani Patrocínio, encarou as barreiras rígidas do espaço literário nacional, permanecendo na literatura não como sujeito discursivo, mas como objeto. Patrocínio aponta para o momento em que este sujeito antes à margem começou a forçar fissuras e assim romper estas barreiras, discutindo como, a partir daquela década, muitos autores marginalizados têm "selado a brancura das páginas com caracteres negros”.

São sujeitos periféricos que romperam a silenciosa posição de objeto para entrarem na cena literária utilizando a literatura enquanto veículo de um discurso político formado no desejo de autoafirmação. A presença desses autores em nossa série literárias não pode ser lida como um dado isolado, mas sim como a conformação de um grupo específico que deseja se fixar no seio de uma estrutura hegemônica. (...) São agora os próprios marginais que buscam representar o cotidiano de territórios periféricos, resultando em uma escrita de alto teor testemunhal. (PATROCÍNIO, 2013, p. 12)

Dentro da minha pesquisa, destaco como marco simbólico para esse movimento a publicação de Cidade de Deus, de Paulo Lins, importante por ser a primeira experiência literária de um autor que utiliza a própria vivência à margem - a possibilidade de narrar os fatos a partir da experiência de ex-residente da favela - para produzir um discurso que une testemunho e ficção. A trilha inaugurada por Lins vem sendo percorrida com as narrativas de outros autores de periferia, como Ferréz e Allan Santos da Rosa, ou por narradores como Luiz Ruffato, que escreve a voz de personagens periféricos. Um exemplo é o Serginho de Estive em Lisboa e lembrei de você, um jovem do interior de Minas Gerais que migra para a capital portuguesa, aterrissando numa Lisboa muito diferente daquela dos cartões-postais. Serginho, que já estava à margem na pequena Cataguazes, sem perspectivas de alívio econômico ou crescimento pessoal, continua à margem na capital portuguesa, convivendo com outros imigrantes e esbarrando com as fronteiras impostas pela sociedade devido ao seu sotaque, gestual, hábitos, falta de 
conhecimento local. O seu exílio, que no Brasil era algo subjetivo, ganha novos contornos com a imigração. Porém, a solidão, falta de perspectivas e barreiras impostas pela sociedade permanecem parte de sua vivência na sonhada Europa.

Retomando a discussão, podemos dizer assim que essa nova geração de autores "periféricos" (seja por viverem na periferia, seja por serem parte periférica do sistema literário, seja por escolherem personagens marginalizados) lançou um sopro de ar fresco no panorama rígido da literatura nacional, conseguindo abrir rachaduras dentro do meio literário brasileiro e ganhar representatividade. Como diz o filósofo inglês-ganense Kwame Anthony Appiah, esse movimento pode - e deveria - ser visto não como ameaça, mas como potência adicional, que pode enriquecer e muito a cultura.

Uma leitura importante para a discussão é a do já citado Cosmopolitismo do pobre, sobre o conceito homônimo cunhado por Silviano Santiago e que surgiu no contexto de um novo fluxo de imigração movido por questões econômicas, marcado pelas tensões entre culturas globalizadas e a valorização do local; pelo difícil equilíbrio entre o desejo de nacionalismo e a tendência para a assimilação homogeneizante; pela expansão dos meios de comunicação e, por consequência, pela inserção de novos discursos dissonantes daquele do pensamento eurocêntrico hegemônico.

No livro, Silviano Santiago aponta para o surgimento de uma nova forma de "desigualdade social" que surge com os novos fluxos migratórios, motivados pela razão econômica e não étnica ou nacionalista, e que escapa ao âmbito legal do Estado-nação. Na metrópole pós-moderna, “o fluxo dos seus novos habitantes é determinado em grande parte pela necessidade de recrutar os desprivilegiados do mundo que estejam dispostos a fazer os chamados serviços do lar e de limpeza e que aceitem transgredir as leis nacionais estabelecidas pelos serviços de migração" (SANTIAGO, 2004, p. 49).

Dessa forma, os imigrantes pobres nas metrópoles pós-modernas se unem aos grupos étnicos e sociais economicamente desfavorecidos (ou socialmente "anacrônicos", como os índios), formando esse novo tipo de desigualdade vinculada a uma nova forma de multiculturalismo, que engloba um processo de desnacionalização do espaço urbano. 
Assim, esse multiculturalismo antigo e eurocêntrico que se queria universal foi abalado pelo pensamento pós-colonial, pela economia globalizada, pelo avanço das novas mídias e pelos novos fluxos migratórios. “Os princípios constitutivos da comunidade imaginada estão sendo minados pela fonte multirracial e pela economia transnacional em que beberam e ainda bebem os estados-nações periféricos e também os hegemônicos", comenta Silviano Santiago (2003, p. 58), que cita também outros motivos para o surgimento de um novo multiculturalismo: o estado-nação passa a ser coextensivo à humanidade.

Ao mesmo tempo, os novos fluxos de imigração econômica, o turismo e a expansão dos meios de comunicação permitem que grupos de indivíduos antes alheios e distantes se conheçam, unam e se reorganizem a partir de acepções de identidade mais amplas do que aquela do Estado/Nação.

Canclini e Marti-Barbero, citados por Renato Cordeiro Gomes (2015), acrescentam que para esse novo multiculturalismo contribuem o processo de aceleração da história marcado pela superabundância de informações e pela emergência de uma crescente interdependência entre nações, culturas e tradições. Appiah, por sua vez, opta pelo termo "cosmopolitismo" em detrimento de "globalização" e "multiculturalismo"; o termo teria origem grega, remontando ao conceito estoico de que na verdadeira natureza humana, o pertencimento à humanidade supera qualquer vinculação a um Estado específico (APPIAH apud GOMES, 2015, p. 15).

O iluminismo, com Voltaire, Diderot e depois Kant, acreditava num desenvolvimento histórico da racionalidade humana, que levaria no futuro à pacificação nas relações entre os homens. Appiah critica esta ideia, apontando que o cosmopolitismo que prega a universalidade acaba por silenciar as vozes dissonantes e alisar as diferenças. Em contrapartida, propõe uma ética do cosmopolitismo. "um cosmopolitismo que passe pelo pluralismo, abrigando a 'esperança e expectativa de que diversas pessoas e sociedade modelem valores diferentes"".

Dois aspectos se entrelaçam na noção de cosmopolitismo de Appiah:

Um deles é a ideia de que temos obrigações que se estendem para mais além daqueles a quem nos vinculam laços de parentesco, inclusive os laços mais tradicionais da cidadania compartilhada. $\mathrm{O}$ outro consiste em levar em conta seriamente o valor, não só da 
vida humana, mas também das vidas humanas particulares, o que implica interessar-nos pelas práticas e crenças que lhes outorgam significado. (APPIAH, 2007, p. 18)

Como já referido, o fluxo de imigrantes pobres nas metrópoles e o avanço das novas tecnologias de informação e de inúmeras redes globais abrem espaço para movimentos políticos transnacionais que expressam novos projetos políticos, éticos e culturais a partir de experiências marginais - e que eclodem no centro hegemônico. A tendência conservadora das nações que zelam pelo localismo, como já vimos com Douglas, é tentar abafar as vozes marginais e dissonantes, enquanto o extremo oposto se arrisca ao valorizar qualquer produção apenas pelo seu caráter de alteridade. Silviano Santiago alerta que, nessa dialética constante entre universal/local, o perigo é identificar a questão da origem e do local de onde nasceu a arte/pensamento para julgá-lo não como substantivo, mas como adjetivo/julgamento de valor. Ou seja: valorizar apenas o que parece universal ou hipervalorizar o local sem julgamento crítico (SANTIAGO, 2004).

\subsection{Entre-lugar e terceiro espaço}

No Brasil, o cosmopolitismo é um desafio também para a construção do país enquanto comunidade imaginada, ou "nação", conforme ensina Benedict Anderson. ${ }^{3}$ Como Antonio Candido sinaliza (CANDIDO apud GOMES, 2015, p. 18), ainda nos debatemos na dialética do localismo e do cosmopolitismo. No entanto, a globalização e o avanço das redes de informação impulsionam a circulação de novos discursos que ora minimizam a centralidade da Nação como significação do mundo e da identidade, ora reforçam as estratégias contra a perda de influências locais.

Culturas antes à margem penetram nesse centro e abrem fissuras, fazendo circular novos discursos e criando um novo lugar - um entre-lugar, como conceitua Silviano Santiago. Uma concepção que, conforme aponta Renato Cordeiro, está bem próxima do conceito de terceiro espaço formulado por Homi

3 No estudo Comunidades Imaginadas, Benedict Anderson explica que, além de recentes, as nações são comunidades imaginadas, soberanas e limitadas: "Ela [a nação] é imaginada porque até os membros da mais minúscula das nações jamais conhecerão, encontrarão, ou sequer ouvirão falar da maioria de seus companheiros, embora todos tenham em mente a imagem viva da comunhão entre eles" (ANDERSON, 2008, p. 32). 
Bhabha. O intelectual, um dos mais importantes do pós-colonialismo, sinaliza um movimento em que as narrativas legitimadoras de dominação cultural ainda baseadas na lógica binária centro/periferia hierarquizadora e eurocêntrica são deslocadas no contexto dessas novas cartografias para revelar um "terceiro espaço" em que convivem momentos diferentes do tempo histórico.

Um tempo heterogêneo conforme teorizado pelo pensador indiano Partha Chatterjee, no qual "a temporalidade não sincrônica das culturas locais e globais abre um espaço cultural - um terceiro espaço - onde a negociação das diferenças incomensuráveis cria uma tensão particular às existências fronteiriças" (BHABHA, 1998, p. 300). Esse terceiro espaço é então um lugar de tensão, marcado pela constante negociação e diálogo entre as diferenças.

Existindo num tempo heterogêneo e não sincrônico, o terceiro espaço é um entre-lugar em que coincidem diferentes momentos do tempo histórico. Ou, como diz Bhabha, a partir dele é possível pensar "o ritual antropofágico da cultura latino americana", aquele que se faz de "temporalidades disjuntivas, múltiplas e tensas, temporalidade de entre-lugar, que desestabiliza o significado da cultura nacional como homogênea, pois é uma cultura dividida no interior dela própria, articulando sua heterogeneidade e hibridismo" (BHABHA, 1998, p. 209).

Esse desfasamento temporal em relação aos antigos centros hegemônicos eurocêntricos de poder e conhecimento passa a ser visto como vantagem por Silviano Santiago, como algo de peculiar e precioso na cultura latino-americana, pois esse entre-lugar abre possibilidades para que absorvamos, embaralhemos e remontemos de forma antropofágica tradições diferentes das nossas, ressignificando essas tradições marginais na adição - e não assimilação - com as hegemônicas. Refletir sobre o novo cosmopolitismo a partir desta perspectiva pode ajudar a pensar as contribuições da alteridade evitando a tendência natural para incorporar suas tradições às nossas e pacificá-las.

Para se pensar em uma ética do cosmopolitismo, como propõe Appiah, é necessário encarar o desafio de reconhecer a singularidade do outro, vendo-o não como ameaça nem como algo a ser canibalizado e homogeneizado dentro da cultura dominante, mas como uma adição, um adendo, um bônus. O cosmopolitismo contemporâneo exige a escuta e a incorporação da vivência, cultura e experiências da literatura, cultura e arte das margens, da periferia. 
defendendo o diálogo entre culturas, Appiah afirma, em entrevista publicada no caderno Prosa \& Verso, que “A arte é também um mecanismo de troca entre sociedades. Além disso, levar a sério a arte de outra cultura fortalece uma ideia de comunidade global na qual todos são importantes" (APPIAH, 2013).

Uma escrita que surge das margens, que nasce seja de um exílio territorial, seja de um exílio social, tem o potencial de deslocar os centros de poder, introduzindo novos discursos. Discursos que, por sua vez, dão voz própria à alteridade e impedem que esta seja silenciada ou abafada, pois agem como elementos com potência própria para fusão e transformação das tradições e do pensamento nacional, até então homogeneizante, elitista e eurocêntrico.

\subsection{Flusser - o exílio como "vertigem da libertação"}

Ao longo deste projeto, destaco, tanto nesta discussão teórica como na novela apresentada em seguida, a trajetória de dois intelectuais que fizeram do próprio exílio um lugar de potência: Vilém Flusser e Edward Said.

Vilém Flusser, o intelectual polonês, que migrou para o Brasil para fugir do Nazismo e voltou a migrar, 30 anos depois, para a França, caracteriza sua saída de Praga como um "desabamento do Universo" - mas também, dialeticamente, como uma "vertigem da libertação e do ser-livre" (FLUSSER, 2007).

O autor, cuja vida é marcada pela experiência de se deslocar entre países, línguas, linguagens, apresenta em sua obra biográfica Bodenlos o conceito homônimo para caracterizar o migrante, o desenraizado, o estrangeiro: Bodenlos, traduzido em português como absurdo, sem fundamento, significa, originalmente, "sem-los", “chão-Boden". Sem solo fixo para criar raízes, o exilado ou migrante é um heimatlos (sem pátria mãe), que se depara com essa sensação de perda, de vazio. Porém, para Flusser, ao superar a sensação de perda, depara-se com um terreno vazio onde pode circular ou se fixar, construir - e pensar de uma forma exterior e livre dos condicionamentos que pertencer a uma pátria nos traz.

O pensador elabora assim a sua filosofia da Heimatlosigkeit, que Marcio Seligmann-Silva chama de "fillosofia positiva do exílio" (2010, p. 27): na ruptura dos laços com a sua Heimat (Homeland, em inglês, traduzido aqui livremente como Pátria-mãe), Flusser enxerga uma libertação do sedentarismo, um mergulho 
no nomadismo. Libertação geográfica que se reflete numa libertação psíquica mental do conjunto de preconceitos, "verdades", do constructo de hábitos cristalizados e de origem esquecida que fazem com que o indivíduo sinta que pertence a alguma pátria.

Seligmann-Silva aponta que Flusser vê na Heimat não uma função ou um valor eterno, mas uma técnica (Technik); como nos ligamos a ela com muitos fios, sofremos com a sua ruptura. Mas essa perda contém em si a semente de liberdade; o poder de superar o luto e de refletir sobre como abandonar velhas verdades é abrir o caminho para descobrir e criar verdades novas. Como diz Flusser, a liberdade do migrante permite que ele "supere a sua pátria, acumulando várias outras pátrias dentro de si”.

O exílio, ou a ruptura com a Heimat, seguindo o pensamento de Flusser, significa portanto uma oportunidade de alcançar um campo livre para o julgamento - ser capaz de pensar sem os preconceitos e hábitos que nos asfixiam cultural e individualmente na pequena ilha geográfica-mental-intelectual em que nascemos e que representava, até a deixarmos, todo o nosso mundo.

$\mathrm{Na}$ obra Bodenlos, Flusser sublinha que todos conhecemos, de alguma forma, a falta de fundamento "e se o negarmos, é que conseguimos reprimi-lo (vitória duvidosa)" (2007, p. 21). Segundo o autor, há os que

se encontram na falta de fundamento, por assim dizer, objetivamente, seja porque foram arrancados da realidade por forças externas, seja porque abandonaram espontaneamente uma situação aparentemente real, mas por eles diagnosticada como fantasmagoria. Os que caíram, portanto, na falta de fundamento ou a escolheram. São os tais que podem servir de laboratório para os outros. Existem mais intensamente, se 'existir' for interpretado como 'viver por fora'. (FLUSSER, 2007, p. 21)

A visão flusseriana da "falta de chão", seja de raízes geográficas, emocionais, culturais ou sociais, reforça a possibilidade de se expandir a ideia de exílio para algo que não é apenas geográfico, como já referido, mas como instância, vivência subjetiva de desenraizamento - que, além da sensação de perda, traz em si a semente de uma capacidade de viver intensa, despida de 
preconceitos e hábitos enraizados e com um olhar mais amplo sobre o mundo à nossa volta.

\subsection{Said - $O$ escritor, o intelectual e o exilado}

A filosofia positiva do exílio de Vilém Flusser pode ser aproximada do posicionamento de Edward Said em relação ao olhar único do intelectual exilado. Para Said, o intelectual que se posiciona na condição de exilado ganha a possibilidade de não se submeter a um poder como a nação. Assim como Flusser, Said viveu entre diversas culturas e línguas; filho de árabes cristãos, nascido em Jerusalém, cresceu no Egito e no Líbano e estudou em escolas inglesas, aprendendo inglês e árabe. Após cursar faculdade nos Estados Unidos, fixou residência em Columbia, em Nova York, onde dá aulas na universidade. Esse percurso "nômade" marcou não apenas a história de vida de Said, mas a sua própria forma de pensar - afinal, o exílio, além de ser geográfico, é uma mentalidade, algo que o exilado carrega consigo como um caracol carrega sua concha para onde quer que vá. Como Flusser, Said foi um intelectual exilado, desenraizado, em constante deslocamento, sem pertencer a uma identidade nacional fixa. E, tal como Flusser, via nessa "falta de pertencimento" uma liberdade; as nações pelas quais passava/vivia eram consideradas como um "posto de observação" (SAID, 2005, p. 67) vantajoso por facilitar o olhar não naturalizado sobre a nacionalidade. Corroborando o pensamento de Flusser sobre a liberdade de pensamento do exilado, Said defendia que, por estar fora do lugar da normatividade, o exilado tem uma visão singular e por vezes mais ampla da sociedade, conforme comenta no livro de memórias Fora do lugar.

Às vezes me sinto como um feixe de correntes que fluem. Prefiro isso à ideia de um eu sólido, à identidade a que tanta gente dá importância. [...] Com tantas dissonâncias em minha vida, de fato aprendi a preferir estar fora do lugar e não absolutamente certo. (SAID, 2004, p. 429)

Convidado para dissertar sobre o papel do intelectual na sociedade, Said levou esse pensamento à frente nas Conferências Reith, transmitidas pela BBC em 1993. No programa, Said defende que o dever do intelectual é, antes de tudo, 
buscar "uma relativa independência" (SAID, 2005, p. 15) em relação a instituições e poderes de modo geral - incluindo no quesito "instituições" língua, tradição e situação histórica e constructos como nacionalidade. Seguindo sua linha de reflexão, o intelectual poderia ser caracterizado como um exilado permanente e dissonante ou

um náufrago que, de certo modo, aprende a viver com a terra, não nela; ou seja, não como Robinson Crusoé, cujo objetivo é colonizar sua pequena ilha, mas como Marco Polo, cujo sentido do maravilhoso nunca o abandona e que é um eterno viajante, um hóspede temporário, não um parasita, conquistador ou invasor. (SAID, 2005, p. 67)

Hall, já referido, explica que o conceito de nacionalidade - ou constructo, como nos mostra Benedict Anderson - é reforçado porque, apesar das guerras, crises econômicas e reviravoltas políticas, a ideia de pertencimento a uma cultura nacional constitui "uma das principais fontes de identidade cultural" (HALL, 2006, p. 47). A cultura nacional funcionaria assim como um discurso ou "sistema de representação", "um modo de construir sentidos que influencia e organiza tanto nossas ações quanto a concepção que temos de nós mesmos". As culturas nacionais, ao produzirem sentidos sobre a nação com os quais podemos nos identificar "constroem identidades" (HALL, 2006, p. 51).

Mas e ao exilado, que não sente pertencer à identidade cultural da nação onde vive - seja ele um intelectual, um migrante, um subalterno, como classifica Spivak, ou um cidadão posto à margem da sociedade? O que resta?

O desmoronamento do universo e a vertigem da liberdade e da autonomia, como explica Flusser, ao refletir sobre sua experiência de vida:

Fui lançado em minha primeira pátria através do meu nascimento, sem ter sido perguntado se eu concordava com isso. As amarras que lá me atavam aos meus consócios (Mitmenschen) foram em grande parte adotadas. Agora, com essa liberdade que alcancei, sou [eu] mesmo que teço as ligações com os companheiros (Mitmenschen) e, na verdade, em trabalho junto com eles. A responsabilidade que carrego por meus companheiros não me foi imposta, eu próprio a assumi. Não sou como aqueles que ficaram em sua pátria, misteriosamente amarrados a seus consócios, mas me encontro livre para escolher minhas ligações. E essas ligações não são menos carregadas emocionalmente e sentimentalmente do 
que aquele encadeamento, elas são tão fortes quanto ele; são apenas mais livres. (FLUSSER, 2007, p. 300)

E acrescenta:

Creio que isso mostra o que significa ser livre. Não é cortar ligações com os outros, mas sim tecer essas ligações em trabalho conjunto, em cooperação com eles. Não é negando a pátria perdida que o migrante se torna livre, mas sim quando ele a sustém (aufhebt). (FLUSSER, 2007, p. 300)

\subsection{Metodologia - Ou, por que uma novela?}

Diante de tão rico panorama teórico, optei por apostar num projeto de ficção que pensasse vários tipos de exílio, os seus desdobramentos e o ato criativo e transformador que a ruptura com uma pátria-mãe pode originar no indivíduo, no seu pensamento, nas suas obras. $\mathrm{O}$ formato ficcional permite falar sobre exilados e deixá-los falarem através das páginas - bordando na tessitura narrativa reflexões teóricas baseadas nas leituras da narradora e pesquisadora, que se revelam fundamentais para que narrador e leitor construam, juntos, uma visão crítica sobre o tema.

A pesquisa bibliográfica trouxe uma bagagem extensa que procurei articular na escrita de ficção de forma fluida, de forma que citações de reflexões não se tornassem argumentos numa disputa para vencer o tema e convencer o leitor. A opção pelo formato ficcional permite citar referências e construir um pensamento teórico tal como numa dissertação padrão; porém, abre a possibilidade de "conjurar" a potência desses "exilados", dando-lhes posição de sujeito dentro do espaço da narrativa.

\subsection{A literatura como mundo}

O exílio enquanto tema adquire vital importância nos dias de hoje, num mundo globalizado fortemente marcado pelo fenômeno das migrações de massa, deslocamentos de refugiados, de identidades fraturadas pelo questionamento de fatores antes determinantes da identidade, como o território, a língua e a nação. 
Por outro lado, desde o início do século XX e suas guerras diversos intelectuais e artistas encontram na viagem, na exploração do mundo e na experiência de viver afastado de sua terra natal uma fonte de estímulos para a criação intelectual e artística. É o caso de autores como Rushdie, Said, Nabokov e James Joyce, Samuel Rawet, entre muitos não citados no presente estudo por falta de espaço. A trajetória pessoal desses autores imigrados, que inscreveram sua importância na cultura ocidental moderna, e o conteúdo por eles produzido revela como o exílio se tornou um tema recorrente e de destaque na literatura, arte e cultura contemporânea.

Numa perspectiva mais ampla, além de ser a realidade de muitos indivíduos, o exílio constituiria uma metáfora radical da condição de todos aqueles pertencentes a um tempo em que podemos perder ou questionar nossos lares, projetos de identidade ou nos sentir desconfortáveis e distantes de sua fala. Afinal, por maior que seja a ligação que se tem com pátria, língua, tradição ou "eu", no mundo contemporâneo o sujeito pressente o quão instáveis são esses projetos e ideias, produtos construídos pela história e por grupos - instáveis demais para se construir em torno deles a própria identidade.

Adorno, em Mínima Moralia e na autobiografia escrita entre 1944 e 1947, no exílio nos Estados Unidos, cujo subtítulo é Reflexões a partir da vida lesada (Reflexionen aus dem beschädigten Leben), propõe uma teoria do exílio modern, atento à figura do intelectual em trânsito - figura que, em deslocamentos que expressam a movimentação da própria contemporaneidade, afirma a ideia de que a casa é passado. Segundo o autor, faz parte da moralidade moderna não se sentir em casa na própria casa; ao mesmo tempo, esse não-pertencimento,

esse exílio é como imperativo moral ao qual deve o intelectual moderno conscientemente curvar-se; é a sua condição de exilado que lhe faz, verdadeiramente, exercer seu ofício: o pensamento crítico. (MIGLIEVITCH RIBEIRO, 2011, p. 153)

A temática adquire importância estratégica para o debate e o pensamento contemporâneo como para a produção da ficção moderna. Said afirma que o romance só existe "porque outros mundos podem existir" (grifo do autor). A escrita pode se tornar uma forma de costura do próprio pertencimento para o 
intelectual ou artista exilado. A possibilidade de criar novos mundos onde se é possível habitar.

Ricardo Piglia define na comunicação "Memoria y tradición" (1990) como mirada estrábica a visão do intelectual deslocado, que consegue se afastar de preconceitos e do senso comum fazendo de seu olhar, trabalhado no estranhamento, uma lente através da qual pode enxergar mais longe e com um distanciamento crítico difícil de se manter quando se está atado afetiva e intelectualmente às próprias origens. "É preciso ter um olho voltado para a inteligência europeia e o outro para as entranhas da pátria" (PIGLIA, 1990, p. 61, trad. minha). Vera Follain Figueiredo comenta:

$\mathrm{O}$ que a experiência da viagem ainda oferecer às narrativas? A resposta está na ideia de deslocamento que lhe é inerente. Deslocamento que não precisa ser geográfico, que pode ser traduzido como um deslizamento até outra enunciação, como uma tomada de distância em relação à própria palavra. Deslocamento como esforço para captar outras narrativas deixadas à margem pelo discurso fechado do poder ou como esforço para sair de um lugar fixo, sair do centro, para ouvir o que o outro tem a dizer. (s.d.p. p. 39)

Ao pensar literatura como deslocamento, Piglia explora como a língua ficcional permite inúmeros desvios rumo à matéria ferida; como consequência, de muros, fronteiras e barreiras que governos, povos e o próprio desenraizado erguem, abre-se uma fissura que deixa passar flashes de memórias, vivências soterradas e toda a força de impulsão criadora tanto tempo contida. Como explica Miglievitch Ribeiro:

Os exilados sabem, sobretudo, que, num mundo contingente, as pátrias são sempre provisórias, fronteiras e barreiras que, num momento, nos fecham na segurança de um território familiar, noutro, tornam-se prisões. $\mathrm{O}$ intelectual exilado atravessou fronteiras, rompeu barreiras (da experiência e do pensamento), a ele é facultada uma visão, se não mais verdadeira, mais original, a do mundo inteiro como uma terra estrangeira que pode levar, otimistamente, a se elaborar novas oportunidades de convívio entre os humanos e, podemos acrescentar, entre os humanos e sua casa, o planeta. (MIGLIEVITCH RIBEIRO, 2011, p. 171) 
É nesse sentido que Vilém Flusser pensa o exilado como um nômade de vanguarda, que, livre da mentalidade de sua terra natal, traz em si a semente para florescer criativamente e a capacidade de construir pontes entre culturas.

Seja em ficção, artes visuais, autobiografias ou microrrelatos, o artista encontra abrigo na arte, fazendo do pensamento a própria habitação. Sua energia represada no período inicial de exílio deságua em obras geniais - que, semeadas num lugar distante, à margem do centro cultural, ganham perspectivas diferentes para falar do mundo. 


\title{
2. Fazendo a América
}

\author{
Anda, vou-te mostrar a terra \\ dos teus pais, avós, antepassados \\ tão antigos que os podes escolher. \\ Este aqui é Noé, de barba por fazer; \\ meteu na arca puro e impuro, bem e mal, \\ inventou o vinho, homem melhor \\ da sua geração (não é grande elogio), \\ teve filhos, netos, é de crer que morreu. \\ Estoutro, não sei bem, era pirata na malásia. \\ Vês as colinas? São tuas, quando \\ as olhas a direito. Realmente tuas, \\ parte de um mundo teu. \\ Sim, isso são filosofias, \\ tens razão. (E tem graça ao ter razão). \\ Anda daí, vou mostrar-te o colete de forças \\ onde era costume, sabes, tratar casos assim. \\ Anótnio Franco Alexandre, Quatro Caprichos
}

\section{1.}

Era um poço pouco profundo; meu rosto poderia se refletir na água, se esta não fosse tão escura, e se eu não estivesse tão nervosa, se as lágrimas não nublassem meus olhos. A aldeia gritava e atirava pedras e eu me encolhia, a água suja o único abrigo depois do que descobriram. Eu não sabia bem do que tinha culpa, se ele é que tinha me levado para o matagal entre as duas aldeias, terra de ninguém. Não tinha culpa se ele era noivo. Mas fatos e dados não calavam a agitação do povo. E ele, ao lado da futura esposa, era mais um espectador, sem levantar a voz para que parassem. Eu não sabia de mais nada. Só queria deixar de ouvir o barulho das pessoas, os empurrões, o hálito de álcool saindo da boca dos velhos junto com palavras feias, o cheiro de pão, suor e cozinhados entranhado nas roupas da mulheres que me empurravam. Fixei os olhos no fundo das águas turvas do poço e usei todas as minhas forças para ficar invisível. Para deixar de ouvir.

No sonho com a aldeia dos meus avós. Antes da viagem para conhecer a terra do meu pai. Antes de saber que havia um poço, onde eles atiravam filhotes de mochos (corujas), porque eram "sinal de mau agouro". Talvez eu também fosse, pensava, ainda hipnotizada pela visão da água escura. 
Meu pai chegou ao Brasil com menos de 1 ano. A viagem demorou 9 dias, e minha avó enjoava o tempo todo no balcão da $3^{\mathrm{a}}$ classe.

Até hoje ele ama o cheiro do mar. Sonha com cruzeiros e passeios de iate, saliva à vista de um arroz de polvo, dourada grelhada - todos os nomes de peixe que nunca comi, aprendi com ele. Foi sempre ele quem me levou a praia. Minha mãe e meu irmão detestam a combinação sol-areia-água salgada, que faz nossos olhos brilharem até hoje.

As gaivotas vêm para a terra quando há tempestade no mar - ele me ensinou, uma vez em que veio me visitar em Lisboa.

Sempre que posso, lá ou cá, vou à praia. Minhas casas sempre foram cheias de conchas, de todas as formas e cores e cheias de defeitos - as preferidas. Gosto de pintá-las com tinta perolada ou esmalte cintilante. Para que se pareçam com as joias que realmente são.

Numa das minhas férias no Brasil, fui a um terreiro e me explicaram: não consigo comer peixe por ser filha de Iemanjá. Grávida, minha mãe já enjoava com a visão de mariscos, e não podia fazer feira por não suportar o cheiro. Quando criança, um dos meus passatempos era resgatar os camarões afogados no molho de uma comida avermelhada típica do Nordeste - aqui em Lisboa acho que nunca vi. Esqueci o nome.

Meu avô adorava comer olho de peixe. Eu não entendia como ele era capaz de enfiar na boca aqueles olhos gelatinosamente grudados em nós, eternizados no momento em que se esgotou a vida. A primeira vez que me forçaram a experimentar um filé de algum pescado, foi como se facas nascessem debaixo da minha pele - escamas, o animal se vingando de quem sustentava seu olhar e ousava engoli-lo, se apropriar dele no ato da ingestão. 
No terreiro os búzios rodaram na concha das mãos da mãe de santo, que explicou: filha de mãe sereia não pode comer seus irmãos. É instinto.

Talvez por isso uma das minhas brincadeiras preferidas na infância fosse brincar de golfinho. Debaixo d'água, competia com uma amiguinha da colônia de férias e sempre batia o recorde de tempo submersa na piscina. Até hoje quando estou exausta afundo na banheira, ouvindo o som do nada da água vibrando pela pele, enchendo os pulmões de alívio.

Embaixo da água a única fronteira é a nossa pele. O oceano que quebra na costa de lá é o mesmo que deixa suas conchas nas areias daqui. É nesse élan aquático - onde o corpo flutua sem a opressão da gravidade e os contornos das coisas se diluem - que se esconde o segredo de tudo. É no barulho surdo do fundo do mar, gravado no interior de cada concha, que se guardam as histórias. Para ouvir, é preciso tapar um ouvido e se concentrar só no que som que ressoa da concha para o outro.

O planeta está mais quente e os oceanos mais ácidos. Os biólogos dizem que é por isso que as conchas estão cada vez mais finas. É assim que hoje elas são tão poucas. É assim que as histórias se perdem.

Uma criança observa o fundo de um poço. A profusão de imagens que o escuro das águas lhe devolve, como se os filhotes de coruja ali afogados ao longo de gerações a olhassem de volta, contaminando-a com as memórias de seus antepassados, enterradas e convenientemente esquecidas. Memórias que, como os pequenos animais, "traziam má sorte" para a aldeia.

Será que a menina esteve realmente perto do poço ou apenas sonhou com ele? E esse sonho, veio antes de saber que era tradição afogarem ali filhotes de coruja? Ou será que foi a visão do fundo do poço que disparou a profusão de imagens noturnas - imagens ou memórias? Talvez ao olhar para o fundo, a menina simplesmente tenha inventado a história da moça encurralada contra o poço pelo povo, acusada de ter se deitado com um rapaz comprometido. Ou talvez, a história da moça e a das corujas estivesse gravada naquelas águas e 
invadisse quem quer que se debruçasse ali; seus gritos se confundindo com os dos pequenos animais se debatendo por oxigênio até o final.

Ou talvez, no confronto com esse final inevitável que o fundo do poço devolveu à menina, tenha ocorrido a "cisão de ver" referida por Didi- Huberman em $O$ que vemos, o que nos olha: um processo inescapável e inelutável; onde o visível nos agarra e nos faz ver fantasmas. ${ }^{4}$

Didi-Huberman afirma que, ao observar um túmulo, este "me olha também (...) porque impõe em mim a imagem impossível de ver daquilo que me fará o igual e o semelhante desse corpo em meu próprio destino futuro de corpo que em breve se esvaziará, jazerá e desaparecerá num volume mais ou menos parecido".

O poço, como um útero escuro, quente dentro da terra, não seria também uma espécie de túmulo?

Minha avó conta como foi dura a viagem de barco com uma criança de colo. Uma vez desceu as escadas para a cabine e teve um desmaio - o menino rolaria degrau por degrau não fosse uma senhora a ampará-la. A história, que mal começara, terminaria aí. No meio do Atlântico.

Mas a história começara bem antes.

Margarida, minha avó, era moça solteira, trabalhadora, bonita. Sabia ler e

$4 \quad$ Didi-Huberman analisa as primeiras páginas de Ulysses, o clássico de Joyce, para falar desse olhar que nos olha de volta, de imagens que, depois de vistas - ou vividas? - nunca mais nos largam, se repetem em símbolos, sonhos, atos falhos - "abrindo a nossa experiência em duas" (2010, p. 37). Por um lado, aquilo que Stephen vê, o olhar da mãe suplicando-lhe que reze ao lado do seu leito de morte dela; por outro, o olhar que a mãe moribunda parece lançar sobre ele, um olhar que vem perturbar a sua capacidade de vê-lo simplesmente, que impõe a imagem impossível de sua própria perda, que nos interpela com o inevitável: "o destino do corpo semelhante ao meu, esvaziado de sua vida, de sua fala, de seus movimentos, esvaziado de seu poder de levantar os olhos para mim. E que no entanto me olha num certo sentido - o sentido inelutável da perda (...)." Mesmo vazios de vida, mesmo fechados, os olhos da mãe de Stephen irão acompanhar o personagem, contaminando os objetos à volta com seu sabor de perda. 
fazer contas - era conhecida na aldeia por vender os pães na feira com as irmãs. Já estava mais do que na época de casar. "Eu tinha muitos pretendentes, mas o seu avô foi o mais sério. Só perdi 'os três' depois de casar”, ela conta gargalhando, numa piada suja que, sem graça, finjo não entender. No início da primavera havia a festa da espiga - as meninas debulhavam o milho repetindo as mesmas cantigas que seus avós e bisavós há muito cantaram, enquanto os rapazes tomavam coragem e vinho para pedir uma dança.

Hoje, já estamos habituados a ouvi-la cortar conversas com versinhos que surgem do nada, como o clichê Oh cachoupa se tu queres ser bonita... ou

\section{Minha mãe casai-me cedo, enquanto sou rapariga: que o milho ceifado tarde não dá palha nem espiga!}

O pai do meu avô já tinha se correspondido com o dela: procuravam uma moça séria em idade casadoira, disposta a imigrar e constituir família. Entre as várias da aldeia, indicaram Guida, a filha do alfaiate.

Meu avô Manuel vivia no Brasil na época. Imigrou aos 16 anos para trabalhar na carvoaria de um tio, em São Cristóvão.

Subia e descia o morro com sacos de carvão nas costas. Dormia num barraco nos fundos de uma casa, coberto por telhas de zinco que deixavam escapar monótonas goteiras quando chovia.

Manuel - era o nome do meu avô - não foi o primeiro (nem o último) da família Martins a tentar a sorte no Rio de Janeiro. Além do tio dono da carvoaria, mais dois tios geriam uma pensão ${ }^{5}$ no Centro, na Rua da Carioca - uma das “pensões para homens solteiros" que, além de hospedar trabalhadores e estudantes, servia P.F.s a um preço viável. Claro que a mão de obra gratuita dos primos do meu avô, recém-chegados ao Rio, contribuía para manter baixos os preços. Sem papéis regularizados, com a família no outro lado do mundo, trabalhavam em troca de abrigo e um prato de comida. E gorjetas. O que lhes permitia ir ao cinema uma vez por mês.

Até hoje meu pai, quando estressado, escolhe um filme aleatoriamente e 
vai ao cinema. Na verdade fiz o mesmo em Lisboa durante muitos anos; preenchia as tardes de sábados sem amigos/família com duas sessões seguidas no Midas, sempre com algum título inesperado de algum diretor europeu/israelita/enfim que (eu) não conhecia. Saía da sessão e já era noite; tinha vencido mais um dia.

Não consigo fazer o mesmo no Rio. Talvez porque não tenha a mesma facilidade de me mover pela cidade como em Lisboa, onde cruzava diariamente quatro bairros a pé em uma hora e pouco. Talvez porque aqui haja horas certas para se circular, roteiros traçados por onde andar; talvez porque "se perder" pode ser algo literal por aqui.

Minha avó sempre foi vaidosa - ainda insiste em admirar suas rugas nos espelhos tríplices da penteadeira. Não reconhece mais os netos, mas descreve com detalhes as fagulhas castanhas nos olhos azuis clarinhos do seu pretendente sério, Manuel Martins.

Ficou tudo acertado como o costume da época; namoraram por um tempo na aldeia ele voltou para o Rio de Janeiro, onde arrumaria casa e emprego, e depois mandaria buscá-la.

Casaram na igrejinha da aldeia, de Nossa Senhora da Alegria, nas vésperas da partida. Passaram mais de um ano trocando cartas. Mais do que juras de amor, as folhas eram um amontoado de contas e cálculos do quanto faltava para trazer mulher (e filho) para a América.

Teu pai teve sorte, um amigo contou: "Meu avô também veio com 16 anos, só que clandestino no porão de um navio - ao chegar, em vez de reencontrar a família, foi entregue a uma casa de menores. Ficou preso por 2 anos até completar a maioridade e poder se juntar aos irmãos."

Meu pai teve sorte. O primeiro emprego do meu avô depois de casar foi na mesma carvoaria do tio - ele e mais imigrantes carregavam sacos de carvões de um lado para o outro, numa peregrinação que só terminava quando o chefe 
determinava o fim do expediente.

Quando o menino nasceu, Margarida pensou em dar o nome de Paulo, mas já havia um na família. Ela não se lembra de quem deu a sugestão, mas depois que ouviu o nome não teve dúvida: Américo.

Esperou alguns meses com o filho na terra, mas valeu a pena: com o dinheiro de meses de trabalho braçal, Manuel montara sua própria carvoaria, com seus próprios empregados.

Quando mulher e menino chegaram, o terreno da carvoaria foi dividido em dois: na parte menor o casal abriu uma quitanda, onde vendiam frutas, arroz, feijão, cereais, balas, o que fosse.

Eu e meu irmão ainda conhecemos a quitanda que, claro, já não existe. Só me lembro que era escuro, cheio de potes de vidro baços com grãos e balas coloridas, e que era ponto de encontro das vizinhas portuguesas da minha avó que, após anos de Brasil, não tinham perdido o sotaque. No final do dia meu avô enchia nossos bolsos de rebuçados - balas, como se diz aqui - devidamente confiscadas pelos nossos pais no caminho para casa. Seus avós não entendem que isso não se dá a crianças, faz mal aos dentes, eles diziam.

Minha avó também teve sorte. Antes dela, seu pai já tinha vindo - um dos muitos alfaiates do norte de Portugal que se instalaram em São Cristóvão. Alguns filhos mais velhos seguiram seus passos para vencer no "Novo Mundo" já que na velha aldeia, a guerra, a falta de trabalho, e a política conservadora de Salazar não estimulava outro empreendimento além de fazer pão ou plantar batata. No Rio de Janeiro, meus tios-avôs trabalharam em cafés e mercearias na Tijuca até hoje comentam como gostavam das frutas, do "povo cordial" e "Ah, da Cinelândia!". Na aldeia, o cinema mais próximo ficava a uns $150 \mathrm{~km}$, significando um evento a que se ia uma vez por ano. 
Por causa do Brasil, meu bisavô chamou uma filha de Iracema, quando todas as outras tinham nomes católicos, ou, no mínimo, convencionalmente portugueses. Por causa do Brasil, um dos meus tios-avôs, Russo, com cabelos ruivos que só numa piada genética nosso DNA mouro poderia produzir, foi pego pela PIDE com livros do Jorge Amado nas malas e "aconselhado" a deixar o país para evitar ser preso.

Iracema é anagrama para América, leio em algum lugar.

Tinha dez anos quando fomos pela primeira vez a Portugal; meu irmão Rafael, onze. O país do nosso pai era a aldeia onde ele nascera e onde, 40 anos depois, ainda vivia toda sua família. A aldeia só tinha três casas: a do tio Luís e a esposa Emília, a da prima Esperança, e a da tia Rosa e da bisavó, que ainda era viva. Era uma velhinha muito curvada que se vestia de preto da cabeça aos pés; passava as tardes sentada ao lado do buraco na parede onde assavam o pão. Talvez por isso tivesse aquele cheiro sempre quentinho entre as mãos enrugadas.

Rafael não acreditava que a televisão só tinha 3 canais - o Brasil da época já tinha 13. Não havia Coca-Cola, nem balas, nem sorvetes - só pão, pera, água, vinho e uma bebida gasosa de laranja que estava a quilômetros de uma Sukita. Na época eu comia carne e, tirando a falta de sorvetes e batatas fritas, não tive problemas.

Os doces da tia Emília eram feios, sempre amarelados ou amarronzados compotas de maçã e pera para se comer com queijos fedorentos mas que, passado o primeiro estranhamento, adocicavam levemente a língua. $\mathrm{O}$ filho de uma prima estava anêmico, diziam, e por isso tinha direito à sobremesa medicinal de morangos com açúcar e vinho do Porto, que supostamente era rico em ferro e dava energia.

Tudo o que eu queria naquelas férias era ficar anêmica. 
Entre as casas da aldeia havia um quintal enorme cujo fim nunca descobri; só conseguia ver o topo dos eucaliptos do vizinho lá longe, e imaginava que o terreno fosse uma fazenda enorme que chegasse até lá. Várias vezes tentei ir mais longe, mas o caminho era monótono: primeiro as macieiras, depois as pereiras, e depois um imenso túnel de parreiras com pouca luz e uvas amargas para o paladar infantil. Ficávamos na parte do quintal perto das casas, das flores e dos animais. Havia a roseira e um tronco partido ao meio, que meu irmão brincava de tirar lascas com um machado. Eu dava nomes a cada flor, conversava com cada uma pela manhã, até que chegassem as abelhas. Então chamava Rafael para ver os coelhos: eles ficavam em janelinhas gradeadas cobertas de serragem, e abríamos com cuidado as gaiolinhas em vão: a ninhada se escondia por trás dos olhos desconfiados da mãe coelha.

Contava os dias para que conseguissem enxergar e se mexer pela gaiola, para poder pegar cada um deles na mão.

Minha bisavó teve vários filhos. As meninas com nomes de flor, Rosa e Margarida, a Henriqueta (ou raposa, por causa dos olhos) e Iracema. Os meninos eram Luís, Carlos, Geraldo, Manuel. Ao menos os que conheci. Não sei se havia mais.

À noite, meus tios-avôs se reuniam na casa da mãe - todos sentados em torno da lareira, que era simplesmente uma quina na parede onde subiam labaredas de fogo, com uma chaminé por onde fugia o fumo, onde eles descartavam restos de mato, cascas de castanhas que iam comendo enquanto bebiam vinho e conversavam, e onde algumas panelas de ferro aqueciam a comida. Eu e minha mãe tremíamos de frio; mas não se podia chegar muito perto do fogo para evitar gripes.

[Até hoje meus tios-avôs recusam aquecedores elétricos; acham que essas inovações são a causa dos problemas respiratórios e pneumonias que assolam a juventude.]

O melhor dessas noites era ficar observando o fogo queimar lentamente as pinhas e as castanhas, enquanto ouvia calada as histórias dos mais velhos. 
Uma vez, tia Rosa contou a história do Tio Russo - que era Ouvidor, uma figura importante na terra. Ele namorou por um tempo, casou e, no dia seguinte às núpcias, devolveu a esposa à família dela. Depois disso, nunca mais se juntou a uma mulher - teve mais de 20 filhos aos quais nunca deu o sobrenome.

Guida e Rosa faziam serviços às vezes para o Tio Russo, que vivia numa das melhores casas da região. No fundo do armário, no meio de suas camisas engomadas, havia um baú fechado a chave, que tirava o sono das então meninas. Um dia conseguiram enganar o tio, surrupiar a chave do criado-mudo e abrir o baú: ali dentro, o vestido da noiva, enrolado delicadamente com a grinalda e as flores de laranjeira já secas do buquê. Mas como assim, vó, por que ele ficou com o vestido? O que será que aconteceu na noite de núpcias? Eu não sossegava até completar os hiatos dessa história.

Os mais velhos não sabiam, Tio Russo nunca disse nada e a noiva "devolvida" muito menos. Os velhos contavam e recontavam essa história, e à noite, quando rodeada pelos móveis, colchas, cobertores antigos, as palavras viravam sonhos e memórias, penetrando sutilmente no imaginário infantil.

Tia Emília era mulher do Tio Luís e responsável pelos mistérios que deixavam meu irmão e eu insones, confabulando histórias de terror durante a madrugada. Mancava de uma das pernas e falava pouco; ia e vinha da horta várias vezes por dia, entrando e saindo de uma parte exterior da casa, fechada por uma portinhola de madeira pela qual tentávamos espreitar pelas frestas - mas era tudo tão escuro que não conseguíamos enxergar nada, nem de relance. $\mathrm{O}$ cheiro era horrível; talvez ela fosse uma bruxa, como aquelas em cavernas rodeadas de ervas e unguentos. Talvez por isso quase ninguém falasse com ela, que passava pelas casas como um fantasma. Um espectro imparável e imperturbável, sempre no mesmo movimento: entrando com baldes de folhas e legumes, saindo com baldes de água com um cheiro irrespirável.

Um dia pedimos ao Tio Luís e ele nos levou lá dentro.

Aguardamos o abrir da portinhola em silêncio. Rafael era mais velho e portanto mais valente, mas dava passos para trás "por causa dos morcegos". 
"Parece a caverna do Batman", disse rindo, talvez para disfarçar o medo; já eu apostava que aquilo era um templo de bruxaria. Entramos atrás do tio.

O teto era baixo e as paredes apertadas deixavam o ambiente ainda mais escuro, quebrado apenas por frestas de luz que rasgavam as telhas quebradas no telhado improvisado.

Paredes sem tinta, manchadas de comidas e fezes e um chão coberto de palhas, com moscas zumbindo por todos os cantos. Eu só queria sair dali, mas alguma coisa me impedia: atração pelo medo, pelo bizarro, vergonha de ser tachada de medrosa, como me chamavam na escola. Rafael segurava o nariz com os dedos, no que o imitei, até chegarmos ao final do corredor estreito.

Eram três, como nós: presos em cercadinhos, eram tão grandes e faziam um barulho tão nojento - eu só queria sair dali. Criar um bicho enorme e fedorento num lugar escuro só confirmava que esse era um segredo horrível, e por isso ficava longe das vistas de todos. Mas para quê criar e alimentar bichos tão nojentos e sujos? De que serve ter um bicho com o qual não dá para se brincar nem pegar no colo - por que não um cachorro, ou coelhos, como os da Tia Rosa?

Eu não entendia o Tio Luís. Ele mostrava cada um dos porcos com orgulho, contando a história de quando nasceram, quanto tempo levaram até engordar, e que faltava pouco para um deles - o mais gordo - estar no ponto. No ponto para quê? Meu irmão parecia mais à vontade, perguntando coisas como o porquê do escuro, se havia morcegos, se o cheiro era deles ou se vinha do cocô que faziam na palha, etc. Já eu, perdi rapidamente a curiosidade.

Só queria nunca ter entrado ali dentro.

Os coelhos da Tia Rosa pareciam tão fofinhos - agora que abriram os olhos ela até me deixava pegar nos filhotes, afastando para o fundo da gaiola a mãe contrariada. Mas eu não tirava da cabeça a história dos porcos - para onde iam quando chegassem no ponto?

Para o fundo da panela, descobri. Uma noite, ainda na aldeia, tive um sonho em que ouvia os traficantes da favela próxima à minha casa no Rio - e eles gritavam "você vai morrer" e "perdeu" uns para os outros, e eu só consegui voltar 
a pegar no sono emendando pai-nosso, ave-maria e glória-ao-pai. Acordei na cama gelada do quarto antigo português - as aranhas gigantes passeando pelo teto -, lá fora uivos de dor profunda, como nos filmes quando alguém estava morrendo, ou nas novelas, quando uma mulher estava parindo. Acordei minha mãe no quarto ao lado, ela também não sabia de onde vinha o barulho; pulei para a cama dos meus pais e dormimos abraçadas até que os gritos se diluíssem na matéria vertente dos sonhos. Mas até neles o uivo entrava: éramos assaltados perto da minha escola, na Cruz vermelha, e, do nada, em vez de levarem nossas bolsas, raspavam a pele do nosso corpo, deixando a carne viva, dura, e rosa à mostra.

No dia seguinte havia festa. Era as boas-vindas para o meu pai, que passara mais de vinte anos sem visitar a terra natal. Uma mesa imensa feita de várias mesas juntas atravessava o terreno entre as casas - e um leitão enorme e amarelo numa travessa de prata, como aqueles dos desenhos animados, só que sem a maçã na boca. Minha avó cortava os pedaços e colocava um pouco no prato de cada um daquela carne rósea e esbranquiçada, que parecia seca e dura, mas se rendia macia ao cume da faca. Há carne de coelho para quem não quiser leitão, avisou Tia Rosa, pousando mais uma travessa na mesa.

Couve com batatas. Até hoje, quando vou à aldeia, é só o que me permito comer.

Na casa da minha avó no Rio também havia um quintal, e além dos alfaces, tomates, couves e, sim, uma exótica bananeira - um galinheiro com várias galinhas. Lembro quando nasceram os pintinhos e eu e Rafael brincávamos com eles na grama verde, tentando encurralá-los contra a parede para agarrá-los por segundos - eles logo escapuliam piando pelos nossos dedos. Meu preferido era o Leozinho, amarelo como gema de ovo. Às vezes eles faziam cocô na mão da gente e até isso era engraçado. Eles não paravam quietos, e nós rolávamos na grama enquanto eles pulavam nossos corpos e fugiam, sempre em bando. Acho que isso durou um verão - eles cresciam depressa, e logo a brincadeira perdia a graça.

Uma vez cheguei a casa da minha avó e fui direto para o quintal ver o poleiro. Os pintinhos agora eram galos e galinhas que botavam ovos, mas a cada semana um deles desaparecia. 
Naquele dia fui ao quintal sozinha e, depois de cumprir o ritual de passar pelo túnel das roseiras e tentar alcançar as romãs balançando nos galhos da árvore, caminhei até as grades do poleiro: dessa vez só havia uma galinha e um galo no fundo do enorme galinheiro, quietos, como que escondidos. Saí dali meio frustrada até que, no caminho entre o quintal e a casa, vi um saco de lixo com penas apoiado no canto da parede. Do lado do saco, uma tesoura enferrujada imensa, tamanho facão de assassino em série, ainda com algumas penas coladas entre as lâminas.

Meu pai tinha acabado de chegar; só podia ser do meu avô.

Na mesa do almoço, o prato do dia: arroz ao molho pardo.

Quando ele morreu, simplesmente não consegui. Nunca mais consegui olhar meu avô nos olhos. Ele deve ter sido bom e honesto, e me arrependo de ser tão infantil. Meu eu adulto sabe que as pessoas têm suas próprias culturas, hábitos, visão de mundo - que não muda com uma simples mudança geográfica - e que nem sempre se encaixa com a nossa.

Mas eu era criança e só via a dor das galinhas.

Talvez, na infância, seja mais fácil estar imerso numa dimensão antropomórfica das coisas, num perspectivismo tal como de Viveiros de Castro, que busca compreender as outras espécies para além da perspectiva humana.

Talvez seja na infância que surja esse desconforto com a atitude antropocêntrica. Ou melhor; observando minha sobrinha de um ano e pouco brincar, vejo que, para Abigail, não há hierarquização entre os meus dedos fazendo marionetes ou o gato que circula entre as suas pernas. Bom, não sou psicóloga, pedagoga, nem especialista em crianças. Mas talvez os homens nasçam pensando que são todos iguais (seres sencientes) e, em algum momento, aprendem a colocar os animais em seu devido lugar - quer dizer, abaixo da espécie humana.

Se a criança não é ensinada, e percebe que há um outro esquema de valores - do qual ela não partilha - deve ocorrer um primeiro choque, um primeiro contato traumático com a naturalização desse pensamento e atitude antropocêntrica. A percepção, em crescendo, da vulnerabilidade de alguns seres 
face a outros. Outros que, guiados pelos seus próprios interesses, agem inconscientemente contra os valores cristãos que ensinam às crianças ao matar animais daquela forma cruel.

O que se pode, sendo uma criança, deduzir após essa descoberta?

A- O que os adultos fazem nem sempre corresponde ao que dizem ser certo.

B- O mundo dos homens é governado pela lei do mais forte - o que até então era inconcebível para uma criança branca de classe média alta estudando na bolha de um colégio particular bilíngue, confiante na proteção dos familiares, dos mais velhos, da polícia, do governo.

$\mathrm{O}$ choque que uma criança sente ao conhecer o habitat dos animais domésticos e seu destino inevitável (a panela) origina várias rupturas na percepção que tem de seus familiares, da vulnerabilidade e efemeridade da vida, de quão diferentes poderiam ser os seus próprios valores em relação aos daqueles que partilham a sua mesma cultura - seus pais, irmão e compatriotas. A indiferença frente a dor do outro - que, como animal, cai na categoria de "objeto/ coisa" traça uma linha divisória entre a menina e os outros; em vez de se identificar com os humanos, mais fortes, a criança se identifica com a vulnerabilidade e impotência dos seres que esperam quietos o seu destino no fundo do curral.

E aprende que o melhor é se fazer de invisível, pois até mesmo avós e tios, supostamente confiáveis, eram capazes de atitudes cruéis com seres mais indefesos, sem precisar lançar mão de qualquer justificativa.

Como confiar, de verdade, na estabilidade das relações, dos afetos, das conquistas, do chão da terra em que se pisa?

Num futuro, não tão distante assim, essa criança será uma moça que estará sempre alerta. Aos sismos. Ao tsunami que vem a seguir ao abalo. Deslocando-se de país em país fugindo do agravar da crise, sem grande esperança de escapar ao aniquilamento. Como se o mundo fosse aquele mesmo curral dos porcos, onde vivemos no escuro e nos alimentamos à toa, até o momento em que nossa carne se torna útil para o predador.

Quem é o predador? Os homens que a subestimam, as mulheres com as quais se mede, os europeus donos de si, os brasileiros que não lhe reconhecem 
como igual. Os fantasmas, as lembranças, a insônia. O amor, como o câncer do pai, irreprimível e independente, comendo tudo por dentro. $\mathrm{O}$ isolamento de não pertencer a nenhum povo, país, clube. Página a página a criança subsiste na moça que lê, ouve, escava as memórias e reescreve, tentando deixar algo de perene, perante a certeza de que o apagamento é inevitável.

Será mesmo? Na dúvida, ela insiste e resiste existindo no papel em que escreve.

Quando viajo com meus pais em Portugal e estamos em algum pequeno restaurante de alguma aldeia do Norte, o menu nunca tem opção para veganos. Para contornar a situação meu pai inventou um truque: ele chama o garçom no canto, explica que a filha tem um problema, que é vegetariana e por isso não pode comer ovos nem carne nem leite, o que é seguido invariavelmente por um ar de consternação e piedade dos empregados. Sempre conseguimos montar um prato de arroz, alface, tomate e batata frita - em enormes porções que os garçons colocam à minha frente com um ar de profunda pena, coitadinha.

Minha mãe amamentou meu irmão até 1 ano - comigo, não conseguiu nem completar três meses. Sua mãe teve oito filhos, e amamentou todos. Duvido que minha avó Guida conseguisse amamentar meu pai e minha tia. Até hoje é mais forte que ela - com Alzheimer, ficou claro para as acompanhantes o momento em que sai da mesa direto para o banheiro forçar o vômito, com a indiferença e naturalidade que só a demência senil traz. Obviamente ninguém nunca soube. Se perguntassem ela negaria.

Ou diria que ninguém tem nada com isso.

A primeira vez que fiquei doente ela me contou a história de uma colega da escola que morreu de tuberculose. Supostamente começou a beber vinagre para perder peso e arranjar noivo. Morreu tão magrinha que não conseguia comer nem 
um pintinho assado, dizia minha avó.

Minha tia sempre teve grandes flutuações de peso - de magérrima para magra - mas ninguém nunca comentou nada. Penso nisso agora, enquanto afasto o prato da minha frente, em mais uma noite em que me esforço e me forço a jantar. Durante anos dividi casas com estranhos e ninguém via; agora vivo sozinha, ninguém vê. É fácil: é só sorrir o tempo todo; ninguém tem nada com isso, repetimos em coro. E é com a voz delas que respondo ao médico que ele está louco, que uma internação não faz o menor sentido. Não sou perigo para ninguém, tanta gente louca solta por aí ameaçando o mundo - e depois, eu é que sei o que é ou não um problema para mim. Não o mundo. Afinal, quem dorme com os problemas sou eu. E convenhamos que o mundo não está em condições de apontar o dedo para ninguém.

Olhando friamente, é irônico: tantas gerações dos dois lados passaram fome e para alguns de nós as refeições são uma tortura diária, uma violência. Minha mãe dividia o almoço com as amigas na faculdade para economizar; meu pai comia de graça no restaurante de um tio e às vezes só tinha essa refeição; Rafael devora um pacote de Oreo em 15 minutos. Estou errada ou sou errada? Só sei que nenhum remédio/tratamento vai curar uma forma de ser que eu não sei de onde veio - mas que resiste ali, ao Alzheimer da minha avó, que não se lembra do nome da neta mas não esquece de como se livrar do peso do jantar.

E de que adianta ficar boa se o mundo não vai se tornar um lugar seguro? Por que me ajustar ao mundo, se ele não irá se modificar para me acolher? Não quero ficar boa. Nem minha avó. Nem minha tia. Queremos o direito de andar com nossos escudos. É claro, seria um alívio se eles não nos pesassem tanto nos ombros o tempo todo. Que houvesse algum escape. Que restasse energia para focar em outras coisas.

Mas se não houver, pagamos o preço. Não há almoços grátis, como se diz em Portugal.

Nem para quem pula refeições.

\section{2.}


contra quanto, estremecendo em mim com folhas,

escrevo no mundo

Que aperto com o amor sombrio contra mim: peixes de grande velocidade, letra monumental descoberta entre poeiras.

E que eu amo lentamente até ao fim da tábua por onde escorre em silêncio aplainado noutra cor: como uma pêra voando, um girassol do mundo

Herberto Helder.

Quando meus se casaram, foi uma tristeza para a família dele. É verdade. Minha mãe era brasileira, tinha feito faculdade, comprado casa própria, carro. Era independente, e nada, nada submissa - como as esposas de um português deveriam ser, segundo meus avós. O maior orgulho deles era ter formado dois filhos em medicina, "a profissão mais nobre do mundo". Meu pai sempre foi apaixonado pelo que fazia - cancelávamos passeios por conta das emergências, o telefone de casa não parava de tocar com pacientes pedindo ajuda; ele sempre atendia. Sua irmã vivia de licença médica e se aposentou cedo por invalidez. Acho que ela se sentiu obrigada a seguir os passos do irmão para ser admirada pela família; afinal, desde pequena dava trabalho, era epilética e ninguém conseguia "curar" suas ausências, nas quais se benzia como autômato, como se seu corpo estivesse ocupado por um fantasma. Talvez por isso tenha estudado neurologia. Se era boa médica, não sabemos, mas de uma coisa não tenho dúvida: aquelas mãos tinham verdadeiro talento para a costura.

O que não deveria causar estranhamento, afinal, o avô dela era alfaiate; mas a profissão morreu na geração dele. Ninguém mais na família lidou com roupas. Profissionalmente, quero dizer.

Minha tia aprendeu a costurar à mão e à máquina sozinha, e fazia modelos e roupinhas para minha prima só de passatempo. O curioso é que ela sempre se vestiu muito mal, como uma freira que, pela modéstia nas vestes, transparece arrogância. Poderia ser uma boa estilista. Ou uma costureira de bairro. Poderia ter um nome próprio, sem viver na sombra do pai, e depois, do marido.

Será que alguma vez ela cogitou essa hipótese?

[Minha tia, conforme o script, casou com um português imigrante no Brasil, cuja ocupação era/é construir e acumular casinhas no subúrbio com metro quadrado até suficiente para a respiração, para alugar a preços absurdos a 
trabalhadores em precariedade e, assim, ir fazendo dinheiro].

Meu pai sempre detestou administrar aluguéis e dizia que isso era lucrar com a miséria alheia, e minha mãe sempre desconfiou de dinheiro fácil; ambos trabalhavam até à noite no hospital, diariamente.

Penso nisso enquanto me pego, às quatro da manhã, fechando mais um frila e aceitando mais um livro-encomenda, desta vez sobre esporte e Rio de Janeiro - o que não poderia ser mais incompatível comigo, mas, escrevo, claro. Ainda hoje, meses depois de ter parado de trabalhar oficialmente por causa do mestrado, me sinto estranha; arrumo frilas, escrevo de graça para sites.

Minha analista diz que isso é típico de imigrantes. Essa cultura do trabalho. De que é só através do sacrifício que se ascende. Essa entrega a 100\% a um ofício, a vida toda - mesmo quando não é mais necessário, mesmo quando já se é idoso, rico a ponto de esconder dinheiro pelas panelas da casa, como minha avó.

Ou como os donos daquele restaurante português, na zona sul velhinhos na cozinha esbarrando nos garçons, anotando pedidos em papeizinhos, contando notas no caixa, aos domingos. Atrapalhando todo o movimento do restaurante, mas registrando cada centavo que entra, cada centavo que sai. Para a gente, o trabalho ancora.

Para muita gente o trabalho ancora. Mas, para que não fincou raízes, a âncora é determinante.

Para quem não tem chão. Bodenlos, como diz Flusser, me explica Russo, um dia no boteco sujo do bairro, quando me dou por vencida e lhe pago uma cerveja. Apesar da culpa em alimentar seu vício. Seu, nosso, - quem não tem um? O importante era conseguir sentar com ele mais uma vez. Russo não tinha nada de eslavo, era descendente de alemães e falava algumas coisas estranhas nessa língua, da qual eu sempre gostei exatamente pelo som de arranhão, ferida, fissura. Bodenlos, ele explica, significa "absurdo", mas pode ser traduzido literalmente como "sem chão". Segundo Flusser (o filósofo que ele deve ter conhecido, porque sempre o menciona em qualquer conversa), "sem chão" é igual a "sem fundamento". Sem raiz, sem chão, sem nada onde pisar - liberdade vertiginosa ou queda sem fim? É preciso uma âncora, e a do Russo é esse copo. A do meu pai são plantões exaustivos e cirurgias de emergência, apesar da quimio; a dos meus 
avós, a quitanda, as reformas nos imóveis alugados, ocupando a cabeça do meu avô até os últimos dias, em que não falava coisa com coisa, sentado na sua poltrona mirando a parede. A de minha mãe também foi o trabalho por muito tempo. Depois de se aposentar, ela passou para um outro nível no jogo da vida em vez de sofrer para marcar sua existência pela insistência, conseguiu construir pontes com o mundo. É impressionante a sua capacidade de inventar atividades e fazer novas amigas de infância em cada grupo que frequenta.

Minha âncora é esse caderno. É essa estante de livros. Deixei ruir algumas pontes; não tenho pressa em construir novas.

Se bem que quando menos esperamos surge algo que nos atrai para o outro lado do rio. E nadamos, indo e voltando - fazendo do corpo a própria superfície de passagem.

A comunidade chinesa em Lisboa é surpreendentemente grande; dizíamos que eles brotavam como cogumelos. A cada mês, uma pastelaria tradicional fechava por conta da crise, enquanto abria mais uma "loja dos 300" (300 escudos equivaliam a 1,50 euro), cheia de roupas, enfeites de Natal, Halloween, relógios, artigos para casa, caixas, papéis de parede, cortinas, utensílio de cozinha de plástico - tudo vindo da China e vendido bem mais barato que o quilo de banana. Ou de pera portuguesa, para ficarmos numa fruta mais local.

A primeira leva de chineses era praticamente invisível; não falavam uma palavra em português, e as interações nas lojas eram semelhantes às que temos com um caixa automático ou com robôs. Além de lojas, começaram a surgir restaurantes com sinos, manekinekos, telhas curvadas e decoração vermelha, que se destacavam na paisagem monótona das pequenas terrinhas. Os chineses tinham uma grande vantagem em relação aos donos de restaurantes portugueses, apesar de não entenderem muito bem nossos pedidos: funcionavam aos domingos, feriados e dias santos - até mesmo Natal e Reveillon. Trabalhavam muito, fosse por hábito ou para pagar as dívidas que os trouxeram até ali: o governo português, num acordo meio obscuro com a China, isentou pequenos empreendedores de taxas durante os primeiros cinco anos de negócios. Quando essa lua de mel 
acabou, as lojas vermelhas com suas lâmpadas de natal piscando eternamente foram desaparecendo, tão rápida e invisivelmente como chegaram.

Algumas famílias ficaram. Principalmente aquelas que tiveram filhos. As crianças iam à escola e aprendiam português; voltavam aos restaurantes ou lojas e trabalhavam com os pais, muitas vezes servindo de intérpretes.

Uma amiga minha, enfermeira, fez um estágio de um ano numa maternidade. Um ano inteiro em que só nasciam crianças ucranianas, chinesas, brasileiras ou angolanas, ela dizia. Ou cabo-verdianos de terceira geração aqueles cujos pais já nasceram em Portugal, que nunca tinham sequer pisado em Cabo Verde, mas que não tinham direito à nacionalidade.

Nos últimos anos, com a crise, o governo português começou a "doar" nacionalidades a aposentados estrangeiros dispostos a comprar imóveis no país. Golden visas. Muita gente me diz, quando conto que vivi lá, que seu sonho é se aposentar, largar tudo e viver com tranquilidade, em Lisboa ou no campo de onde vieram os avós.

Eles não fazem ideia do que é Lisboa. Muito menos do que restou do campo de onde vieram seus antepassados.

Minha mãe veio de São Luís, Maranhão - mistura de índios, portugueses, espanhóis e holandeses. Nasceu loira de olhos claros. Um perfeito exemplar de brasileira. Até eu ter uns oito ou nove anos, minha avó e tia paternas disfarçavam a animosidade. Um dia minha tia explodiu: era um absurdo seu irmão casar com uma brasileira; ela estava tentando limpar seu sangue sujo de nordestina na família.

Até hoje, nem eu nem Rafael falamos com minha tia. Usamos o sobrenome materno. Meu pai, se se ressente, disfarça bem.

Talvez isso explique porque, quando cheguei aos 17 anos para estudar em Lisboa, tenha ouvido do meu tio-avô que tinha $50 \%$ de direito de viver ali. Afinal, meu sangue maranhense não me permitia pertencer totalmente a Portugal.

E meu sangue português não me deixava ser totalmente brasileira. 
Tenho um amigo nascido em Paris e criado na Bélgica, que fez faculdade em Lisboa e pós-graduação em Londres e Berlim. Sua mãe é alemã, o pai é transmontano - o casal se conheceu numas férias no Rio de Janeiro e se reencontrou, anos depois, em Lisboa. O reencontro rendeu um final de novela, com casamento e dois filhos.

A mãe desse meu amigo, alemã, Sabine, sofria bullying de toda a família paterna dele. Criticavam o fato de ela conversar em alemão com as crianças, que assim nunca seriam portuguesas - apesar de falarem português com o pai. Sabine é loura de olhos azuis, a pele branca-rósea nórdica, um sorriso de dentes brancos sempre nos lábios. Ela nunca deu ouvidos - criou seus filhos como queria. Hoje eles são fluentes em pelo menos quatro línguas. Mas os tios e tios-avôs da aldeia em Trás os Montes ainda a chamam de a alemã, e não consideram Sebastian e sua irmã totalmente portugueses.

Talvez nenhum deles se considere também. Uma mudou-se para os EUA depois da faculdade e nunca mais voltou; o outro perambulou por Londres, Berlim, ficou três anos no Brasil. Acabou voltando por motivos econômicos. Esse meu amigo acha que sua casa é Lisboa, embora, dos seus 36 anos, só oito tenham sido vividos nessa cidade. Se bem que a última notícia que tive dele é que estava morando novamente em Londres, começando do zero pela - sei lá - quarta, quinta vez.

Conto sempre a história de Sabine para a minha mãe, que durante anos se sentiu rejeitada pelos parentes do meu pai por ser brasileira.

O problema não era ser brasileira, alemã, finlandesa, inglesa ou francesa.

Era não ser portuguesa de raiz.

Eu quero fazer amor, mas meu cabelo cheira como a guerra e fuga e fuga. Eu quero me deitar, mas esses países são como tios que te tocam quando você é uma criança adormecida. Olhe para todas essas fronteiras, espumando pela boca com corpos quebrados e desesperados. Eu sou a cor do sol quente na cara, os restos de minha mãe nunca foram queimados. Eu passei dias e noites no estômago do caminhão; eu não saí a mesma. Às vezes parece que outra pessoa está usando meu corpo.

Warsan Shire, "Conversations about home (at a deportation centre)." 
Por incrível que pareça, Portugal era um dos lugares que eu mais odiava quando criança - quando ainda não conhecia nada do globo além de São Paulo, região dos Lagos, Petrópolis. Lembro de chorar de revolta quando meu avô, num raro momento de afeto, me colocou no colo me chamando de "portuguesinha". Fui crescendo, esgotando os livros da biblioteca da escola, da Tijuca, do Grajaú; minha falta de à vontade com a cidade era tão óbvia quanto meu tom de pele, que destoava da juventude dourada de sereias urbanas da zona sul. De biblioteca em biblioteca eu sufocava no balneário carioca sem ter a mínima ideia do porquê.

Wanderlust é uma palavra que está na moda, mas não traduz o que eu sentia ao longo da adolescência. Fernweh - essa melancolia de estar preso em um lugar, talvez, mas não era isso... Homesickness, ou Heimweh - saudade de casa, dor de estar longe -, mas uma saudade de uma casa que não se sabe qual é.

[Quem sou eu para ousar falar de saudade depois de Fernando Pessoa?]

Com quinze anos passei um mês na Inglaterra, hospedada na residência de uma família local - primeiras férias longas sem a família. Não fiz nenhuma das loucuras que meus colegas da escola de inglês faziam, não experimentei drogas, álcool, embora minha carteirinha falsa me permitisse entrar e beber em qualquer pub. Mas rodei muitos sebos. Comprei muitos livros. Escrevia muito - durante as aulas, na cama, em casa, quando tinha medo de descer e ser obrigada a jantar com uma família estranha. $\mathrm{O}$ que pode parecer solitário e melancólico era absurdamente libertador. Era a saída ideal: depois do vestibular, após garantir minha vaga numa faculdade pública, ia estudar lá fora.

Mas as faculdades e a vida na Inglaterra ou na Alemanha, minhas primeiras opções, estavam fora da nossa realidade econômica. E, sendo sincera, só queria ir embora, para onde, tanto fazia. Até porque poderia sempre voltar. Pensava.

A opção por Lisboa surgiu ao conhecer e fazer amigos portugueses online (ainda época do MIRC, veja bem). Lisboa e os portugueses com quem falava pela internet não pareciam ter crescido no ambiente medieval da aldeia do meu pai. Eram jovens normais, como os de qualquer lugar do mundo, com as mesmas referências musicais, literárias, que viam Seinfeld, Friends, enfim, como qualquer um de nós por aqui. Aos poucos a ideia foi crescendo, ganhando força e 
argumentos. A universidade era pública, o ensino de qualidade; o custo de vida, na época, semelhante ao brasileiro. E Portugal ainda vivia as glórias da Expo 98, quando a União Europeia escoava para lá milhões, devidamente investidos em estradas, bairros chiques, parques e outros elementos cenográficos. O clima de euforia econômica atraía muitos imigrantes, como depois vim a perceber.

- Faz o que o teu coração mandar - dizia minha mãe.

- Você quer um tempo de calma para pensar no que fazer, ficar numa nuvenzinha uns seis meses quieta, é isso? - meu pai perguntou.

Sim, era isso. Fiquei dez anos.

Aos 17 anos, meu pai cursou um ano na faculdade de medicina no Porto. Era muito frio, só havia um cinema na cidade - ele conta -, as pessoas assistiam durante um mês os mesmos dois ou três filmes. Ele voltou logo, no que foi bemrecebido. Por isso me deixou ir. Jurava que eu não aguentaria muito tempo também.

Bem, ele se enganou.

Cheguei a Lisboa, tão cantada em versos que nem me atrevo a descrever; capital da nação que deu mundos ao mundo,, como diz a socióloga póscolonialista Sheila Khan (2015, p. 26), ou de um país onde sonhar se tornou um clichê, ${ }^{6}$ segundo a designer Wasted Rita (a Banksy portuguesa). Escolho meu quarto por um anúncio de jornal e vou parar na casa de Teresa, com uma parede cheia de livros e discos e um filho de três anos. Meu pai conversa com ela e acerta o pagamento - me abraça e, quando a porta da rua se fecha, percebo que estou sozinha. 
Maria está encolhida a um canto, imóvel, os olhos fixos num ponto vago à sua frente. $\mathrm{O}$ calor do seu sangue arrefece e deixa sem misericórdia de aquecer o que nela resta ainda vivo. Imagina que avança novamente, que corre, que foge, que consegue por fim o seu lugar no mundo. Mas que lugar lhe cabe neste latifúndio?

(BARRENO; HORTA; VELHO DA COSTA, 2010, p. 234)

Saio do corredor e me tranco no quarto, meus 17 anos de vida resumidos em duas malas de 23 quilos. Falta uma semana para o início das aulas. Passo os dias no quarto, sozinha - está frio e não tenho coragem de atravessar a porta para a sala ou cozinha, não consigo me mexer.

Teresa flutua pelos cômodos o dia inteiro de camisola, e às vezes bate na minha porta com comida, ou com velinhas aromáticas para iluminar meu quarto. Não trabalha - licença médica. Ouve muita música, fala pouco - às vezes entro na sala e a pego com os olhos fixos na estante de vinis, observando o nada.

Como meu avô nos últimos dias.

Seu filho, o Tiaguinho, voltava das aulas com desenhos estranhos; anjos azuis, cruzes, a mãe com asas. A professora ligava da escola, mas Teresa não queria atender. Não queria falar com ninguém. No telefone a mulher preocupada confessou: o menino tem medo de que a mãe morra. Que pedia para a professora rezar, que falava de anjos. Eu escutava tudo quieta, garantia que a mãe do menino não estava em casa mas estava tranquila, era só uma depressão leve. O Tiago comia bem, tinha toda a atenção do mundo em casa, eu dizia. Mentia e mentia por ela.

Quando a Teresa e o marido, o Miguel, brigavam, a criança batia na minha porta e pedia para dormir no meu quarto. Ficávamos enrolados debaixo do edredom, cantando baixinho para não ouvir os gritos. Ele era muito pequeno - seu corpinho debaixo da flanela do pijama cheirava ainda a óleo Johnson. Quando eu não sabia mais o que cantar, contava histórias.

A que ele mais gostava era a da Nica formiguinha. Era uma peça sobre uma formiga que perguntava a todos os bichos e plantas da floresta "qual era o melhor do mundo para se ser feliz". Cada ser dava uma resposta diferente, e ela não saía do lugar. Quando acabava de falar com um bicho ou planta vinha um refrão, que o Tiaguinho exigia que fosse acompanhado com cócegas nos seus pés: 
Eu sou Nica formiguinha quero encontrar/um lugar maravilhoso/ e feliz então ficar - cócegas e risadas e o pedido de mais uma vez, Maria!

Não sei o porquê, mas eles só me chamavam de Maria. Eu não me importava. Na época eu era uma garota cuidando de um menino de três anos, num quarto mínimo onde mal cabiam meus livros, com uma janela que dava para telhados cinzentos e seus pombos. Outra vida, outro nome - o mais simples possível, aquele de qualquer portuguesa nascida antes de 1960.

Como elas, também sou uma Maria alguma coisa.

Uma vez passei pela sala e o corpo de Teresa estava lá, encolhido no sofá, chorando. Nunca soube consolar pessoas, mas estávamos apenas nós duas em casa; sentei ao seu lado e cruzei seus ombros num abraço. Teresa deitou a cabeça em meu colo e aos poucos soltava a represa do choro - de dor, desespero, alívio. Nunca fui boa para consolar pessoas. Mas o que o outro sente me invade fácil, portanto, ouço bem histórias de silêncio.

Era como se ela tivesse atravessado um oceano e tivesse a primeira visão da terra.

Passei os dedos pelas mechas loiro angélicas; as raízes negras denunciavam pelo menos três meses sem tinta. Há quatro meses não saía de casa, confessou. Lá fora o vento uivava; as gaivotas cinzentas paradas no telhado do prédio vizinho - eu pergunto se não quer dar uma volta. Não conheço nada, nem ninguém, vamos no parque antes que o Tiaguinho volte da escola, vamos? Insisti. Ela concordou, reticente.

Depois do choro, parecia com mais energia. Eu não sabia que ela tinha parado com os remédios - e que aquilo era só o início da subida da montanharussa, a famosa mania.

Fomos a uma loja de discos; a uma livraria; à farmácia comprar tinta de cabelo; à mercearia comprar espinafres. As pessoas a cumprimentavam na rua como se ela fosse uma celebridade.

Mas talvez fosse apenas porque ela não saía de casa há tanto tempo.

Na livraria, fui capturada por dois livros: Medo e Horto de incêndio, 
ambos do Al Berto. O Al Berto era lindo - Teresa disse. Morreu de Sida (Aids) mas viveu muito, estava toda sexta à noite no Frágil. ${ }^{7}$

Podemos ir uma noite dessas ao Bairro, mas não é a mesma coisa, os miúdos de hoje não sabem curtir como antigamente - completou.

Ao chegar a casa me fecho no quarto e leio os poemas: uma Lisboa estranha vai me contaminando página a página, a capital de um país desabitado como os meus dias, sombrio como o inverno que chegava. Uma cidade onde a realidade devora os sonhos - onde eles sufocam como as lágrimas no travesseiro. Onde a ausência não é descrita com a tristeza irônica à portuguesa de Alexandre O’Neill - mas como um abismo mais vasto que o mar. E que mesmo assim, é percorrida pelo vento dos trópicos, alado e lisérgico, que embriaga turista e morador, escritor e leitor.

E imigrante.

por trás dos muros da cidade no seu coração profundo de alicerces de argilas e de sísmicos arroios - cresce uma voz que sobe e fende a brandura das casas da escrita dos inumeráveis povos quase nada resta - deitas-te exausto na lâmina da lua sem saberes que o tejo te corrói e te suprime de todas as idades da europa Al Berto, trecho de "Lisboa 1" (1997, p. 41-42)

Munida desses livros fantasmáticos, não me sinto tão sozinha. Parece que alguém vai me guiando pelas ruas, colocando significados como tesouros secretos em cada esquina. Só eu e ele vemos; portadora do segredo desses poemas, não estou mais só.

Apesar de ser uma Maria qualquer.

As cidades, como sonhos, são construídas por desejos e medos, ainda que o fio condutor de seu discurso seja secreto, que suas regras sejam absurdas, as suas perspectivas enganosas, e que todas as coisas escondam uma outra. (CALVINO, 1990, p. 44) 
Apreender uma cidade é detectar esse fio condutor do seu discurso, o seu código interno. Descrever e rearticular esse fio é a tentativa de ler a cidade, que parece um quebra-cabeça ilegível, semelhante ao sonho. O segredo talvez fosse ouvir - ver a cidade-corpo com um rio, que, como o sangue, corre por dentro da pele movido por nossas palpitações. Uma cidade-corpo que, segundo Al Berto, carrega em si todas as idades da Europa, a tosse dos cacilheiros, mendigos, o cenário de jardins solitários. Decifrar/ler essa cidade é cifrá-la novamente, é reconstruí-la com cacos, fragmentos, rasuras, vazios, jamais restaurando-a na íntegra. Escrever essa cidade é inscrevê-la novamente no nosso mapa pessoal.

Mas quem consegue ir tão a fundo na leitura a ponto de descobrir a Lisboa apagada por outras, que, de forma babélica e labiríntica, vão se superpondo à anterior?

Vou a pé do Campo pequeno ao Marquês de Pombal, sento no Parque Eduardo VII, sigo pela Avenida da Liberdade e suas amendoeiras de folhas castanhas em fogo até a Baixa, onde o Terreiro do Paço me embala com seu cheiro de mar. De repente eu, o poema e a cidade somos um, construídos e destruídos grão a grão de areia, deixando entrever as outras Lisboas enterradas, submersas, escondidas atrás da dor de todas as ruas vazias, como o poeta diz. Percorridos pelo vento frio lisboeta, paramos - eu e livro - à beira do Tejo cinzento, anestesiados de solidão, bêbados de incerteza quanto o futuro.

As aulas finalmente começam - na universidade, sento sozinha no fundo, ainda não conheço ninguém. Numa dessas aulas intermináveis em que penava para destrinchar algo do sotaque incompreensível do professor, reconheço o nome Benjamin e risco no caderno, sem o menor contexto, o pouco que capturo da fala: "a cidade se vinga pela memória".

Leio melhor mais tarde: Benjamin diz que a cidade se vinga pela memória, opondo-se à atrofia da experiência, substituída que fora pela vivência, pelas impressões que desaparecem de forma instantânea, sem se incorporarem à memória. Para além da ordem e da medida, ele procura a cidade invisível da memória involuntária infantil, de densidade de afetos, pulsões ocultas, desejos e medos, ainda que o seu fio condutor seja secreto, suas regras absurdas, como num sonho. $\mathrm{Ou}$, como escreveu Calvino, ainda que todas as coisas escondam uma outra. 
É a memória de quem que me assalta à beira desse rio?

$$
\begin{array}{r}
\text { desejaste um país de silêncio } \\
\text { de chuvas salgadas - sem caminhos nem sonhos } \\
\text { tiveste um país sombrio } \\
\text { onde a realidade devorou o delírio e } \\
\text { ficou desabitado - este país nocturno que geme } \\
\text { contra a solidão do corpo - perguntas-te } \\
\text { que espécie de lume cospem os cardos? } \\
\text { caberá o mar dentro da tua ausência? }
\end{array}
$$

Al Berto, trecho de "Lisboa 2" (1997, p. 41-42).

Como meu pai ensinou, a terra está cheia de gaivotas. Dez anos depois elas não formam mais uma imagem idílica, mas um inferno marítimo de aves. Voam confusas de terra em terra sem nunca ter paz. Eu também fujo da tempestade; eu também olho para céu, mar e terra e não sei onde pousar.

Estou no iate clube do Rio de Janeiro com meu noivo, naquela bolha californiana de idosos rosados e prósperos, e adolescentes se entupindo de batata frita e cCoca-Cola, tudo na conta dos pais. O ambiente à nossa volta é constrangedor; são três da tarde e aparentemente ninguém trabalha nem estuda; como em uma coreografia, os sócios afundam nas poltronas da varanda olhando longinquamente para o cais ao fundo, intercalando reflexões sobre a vida com goles lentos de gin tônica e punhados de pipoca - combinação esdrúxula, comentamos. Eu me esforço para atingir um nível de entusiasmo, o suficiente para convencê-lo de que o cais é o local perfeito para a nossa festa de casamento afinal, me lembra o Tejo, os navios ancorados em Santa Apolónia, o cheiro de óleo e peixe, as gaivotas rodando céu acima, indo e voltando em bandos, anunciando chuva. Adoro gaivotas, meu pai também, insisto.

Numa festa aqui à noite se algo aparecer voando ou é morcego ou barata voadora, ele diz, rindo. Não sei o que me faz tremer, se o nojo, o horror ou a simples frustração; nem termino meu drink, peço logo a conta. Aquele lugar era cheio de árvores, deveria ter mais morcegos que Botafogo, penso com uma certa tristeza. Não sei explicar minha vontade de ir embora; parece que a geografia mais uma vez me expulsa. 
Rabisco mentalmente no meu caderninho: menos um lugar no Rio de Janeiro onde circular em paz.

Gostam de nós brasileiros, todos nos tratam tão bem, querem estar próximos. Somos o país do futuro. Como os EUA já foi.

São tantos sorrisos. Mas todos sabem que não somos mais do que novos ricos, provincianos deslumbrados com a importância que, por motivos econômicos, de repente nos dão, maravilhados com tanta atenção. Todos sabem.

Eu não tinha lido Silviano Santiago. Nem Rushdie, nem Bhabha. Tinha poucas armas - além do desprezo - para me defender.

Durante a faculdade, aprendo a escrever em português lusitano com perfeição. Meus colegas de faculdade eram de vários cursos - ouvíamos brit pop, new folk e a cena avant rock portuguesa, trocávamos livros e discos e a minha nacionalidade era como usar sapatos azuis em vez de pretos ou castanhos - como definiu uma amiga. Dividindo uma casa com uma menina do Alentejo, saindo só com portugueses, meu sotaque se aguentou perfeito durante uns dois ou três anos. E eu era sempre elogiada por falar português tão bem.

Quando falava. Porque, metade do tempo, passava calada - a pele clara combinada com roupas de fast-fashion eram o meu disfarce de estudante portuguesa.

Com meus colegas da faculdade, vivia uma espécie de bolha: eles enfatizavam que não havia tanto preconceito e eu evitava contatos externos que contrariassem essa visão confortante. Na maior parte do tempo estava segura: só desmontava entre estranhos, quando alguma expressão escapava e percebiam de onde eu vinha.

Eu só queria ser um deles, normal, não "a brasileira". Quando descobriam, as pessoas falavam comigo num sotaque tatibitati aprendido nas novelas. Uma vez uma colega se espantou ao perceber que eu era brasileira e 
pediu para eu ensiná-la a sambar. Não provoques que ela morde - disse uma colega, que já sabia que meu copo estava sempre cheio quanto a este tema.

Parece que Witold Gombrowicz era conhecido como "o polonês" em Buenos Aires. Embora haja relatos de que ele não se importasse minimamente com o apelido, o escritor diz, em seu diário:

Minha situação como escritor polaco está se tornando cada vez mais escabrosa. Não tenho ânsia de representar nada além de mim mesmo: apesar disso, o mundo impõe-nos essas funções representativas contra a nossa vontade e não é culpa minha que para esses argentinos eu seja um representante da literatura polonesa moderna. Sendo assim, tinha uma escolha a fazer: ou ratificava esse estilo, esse estilo da pobreza de relações ou o destruiria - e essa destruição custaria a informação mais ou menos positiva que já havia sido construída, e seria certamente ruim para os nossos interesses enquanto poloneses. (...) Sou um homem com um distinto senso de dignidade nacional, e um homem assim, mesmo que não seja ligado à sua nação pelo patriotismo, sempre irá manter a dignidade de sua nação mesmo que seja apenas porque não consegue separar-se dela, e será sempre um Pole aos olhos do mundo. É por isso que qualquer humilhação que a nação sofra atinge-o pessoalmente perante os outros. Esses sentimentos, de alguma maneira forçados e independentes de nós, são cem vezes mais fortes do que tudo o que aprendemos.

Quando somos inundados por um sentimento como este, que é mais forte do que nós, agimos de forma cega e esses são momentos muito importantes para os artistas, porque é quando os ataques formam suas bases e uma posição frente a uma questão conflituosa é delineada. O que eu disse? Percebi que apenas uma mudança radical de tom poderia trazer a libertação. Tentei, anteriormente, indicar condescendência em minha voz e comecei a falar como alguém que não confere grande importância às ligações a uma pátria cujo passado importa muito menos que o futuro, uma nação para quem a lei máxima é a lei do presente, a lei da máxima liberdade espiritual no presente momento. (...) Não. Nós não somos, disse, os herdeiros diretos da grandiosidade do passado ou de sua insignificância, inteligência ou estupidez, virtude ou pecado, e cada pessoa é responsável apenas por si própria. (GROMBROWICZ, 2012, p. 8. Tradução minha) 


\section{4 .}

Em 2008 veio a crise, e os primeiros a perderem os empregos foram os imigrantes. A xenofobia ficou mais agressiva; eu tinha sorte de ter passaporte português, feições mediterrâneas e me misturar bem na multidão com os locais. Não havia empregos qualificados para quem tinha curso superior; passei um ano carregando caixotes na feira do livro, junto com uma doutoranda em química, uma assistente social e uma mestranda em biologia.

O resto do tempo, quando não conseguia trabalho, ficava em casa vendo Oprah, à base de tofu e Coca zero.

Evitava ônibus, fugia dos cobradores no trem. Gastava o mínimo. Mas o câmbio era alto, não havia como fugir.

Uma amiga com os pais imigrantes na Suíça sempre contava a história de uma família que dizia, no Alentejo, ter feito fortuna em Genebra. Uma vez seus pais foram visitá-los e descobriram que eles jantavam toda noite macarrão e salsichas para juntar dinheiro. Com esse método, construíram uma "mansão" cheia de eletrodomésticos modernos numa aldeia minúscula quase na fronteira com a Espanha. Era onde passavam as férias uma vez por ano, e para onde esperavam voltar antes de morrer. Quando os eletrodomésticos já estivessem fora de linha.

Minha mãe tinha uma medo inconsciente de que eu passasse a me alimentar só de miojo ou azeitonas - ficar parada sem trabalhar só me tirava o apetite. Tentava gastar o mínimo por orgulho também, confesso; era difícil pedir dinheiro a eles; era uma confissão de que tinha falhado.

Meu pai dizia que aquilo era só o início, a crise ia piorar. Eu não queria mais ser jornalista; odiava tevê, rádio era impossível com o meu sotaque, os estágios em jornais eram insuportáveis com suas matérias que alternavam incêndios de verão anuais, dicas de investimento, vidas de celebridade. Queria trabalhar numa livraria, ou melhor ainda, numa editora.

Acontece que todo estudante de humanas sonhava trabalhar em livrarias naquele verão, portanto eu, como brasileira, era a última da fila. E numa editora o funil era ainda mais estreito. Uma delas recusou meu currículo porque alguém que 
não cresceu ouvindo a musicalidade da língua portuguesa (sic) não é capaz de fazer um bom copidesque. Outra vez, exausta no final do trabalho na feira do livro - o mais perto de onde consegui chegar dos meus planos -, ouvi de um cliente mais idoso o clássico - e sempre tão desarmante - volta para a sua terra, aprenda a falar português antes de imigrar.

Estava cansada de lutar. Um amigo acenou com a probabilidade de frilas de revisão no Rio de Janeiro. Não custa tentar, diziam meus pais.

Como custava. Na minha última casa em Lisboa, contei cada uma das dezoito paredes. Toquei as duas portas de vidro da pequena varanda de onde me debruçava para a rua. Repassava memórias de tudo o que vivi ali, impregnadas na pele como o cheiro de tabaco na estampa floral do sofá. Os furos queimados no colchão, tapetes e colcha, marca dos cigarros de cada amigo que por ali passou. Cada festa, reunião, jantar, cenas passando como flashes enquanto eu tentava, fazendo as malas, apagar, deixar ir, dormir. Os almoços de sábado na época em que eu cozinhava para oito pessoas. Os primeiros passos da Odete, meu talismã canino, na época tão pequena que tinha medo de esmagá-la quando ela acompanhava atenta meus movimentos na cozinha.

No meu último trabalho oficial como jornalista, voltava cedo da revista, dentro do comboio que passava pela marginal - olhando o mar pela janela, estranhei as ondas tão altas.

Foi no dia do terremoto. A fissura no alto do teto da sala virou rachadura após o abalo.

Dias depois fomos informados numa reunião de pauta que a revista tinha falido. Eu estava oficialmente desempregada. Tinha um quê de excitante nisso tudo, confesso. Fui para o trabalho achando que finalmente ia receber um aumento (que prometiam há uns seis meses) e acabei na rua com os outros colegas, que limparam quase todos móveis do Ikea do escritório para casa. Fiquei com um abajur de chão e uma mesinha laka, o que ao todo não somava 15 euros. E ficaram em Portugal: não consegui trazer comigo no avião.

Quando os subempregos de verão acabaram, não havia mais como me sustentar. Passava os dias em casa vendo o tempo escoar entre programas de tevê com uma amiga brasileira, recém-divorciada, que não tinha para onde ir senão voltar. 
Você parece serena com a decisão de ir embora - essa amiga disse. Meu pai nunca me pediria isso.

Lembro desse dia, do comboio: as ondas altas, o risco da terra tremendo quando o chão já não era firme. Parecia que eu vivia sob anestésicos, tranquilíssima embora plenamente consciente do tsunami que vem depois do abalo sísmico.

Eu serei eu com todas as minhas questões em qualquer lugar do mundo, então tanto faz - ao que ela assentiu, sem me dar muito crédito. Ouvíamos Magnetic Fields e comíamos azeitonas do Leste europeu com café. Era o que havia.

Acertei, ainda sou eu. Tirando a alegria. De voltar para casa. Para a minha casa.

Eu disse que viria um tsunami e era só isso que sabia, sem detalhes. Rezava para não sobreviver e ter que recolher os destroços.

Ainda hoje desconfio do mar, desconfio das ondas. Elas vão e vêm exatamente como no dia do abalo - no terremoto as coisas não tremem, elas balançam, de um lado para o outro até você duvidar da própria sanidade. Observo o mar e espero; a onda parece que não quebra nunca. Quando me aventuro nas águas elas me reclamam e puxam logo para a parte alta, onde meus pés não alcançam, só para me atirar de novo à areia. Às vezes dá tempo de ficar uns segundos deitada, observando o céu. Sentindo a espuma apaziguar o corpo, lixando como se com pedra-pomes. Os dedos, pernas e pés afundando na areia, como se parte da paisagem, uma concha qualquer.

$\mathrm{Eu}$, que recolho e escolho conchas como se pedras preciosas.

Quem mais o faz?

\section{5 .}

You broke the ocean in half to be here only to meet nothing that wants you Nayyirah Waheed, "Immigrant"

O mais estranho de "voltar para casa" é me reacostumar ao silêncio. Quando foi que ele se tornou normal? Horas e horas mudas até o momento de ir 
deitar. Meus poucos pensamentos vão se perdendo no escuro da mente, como quem baixa o volume até o mute, mergulhando no nada.

Sem falar vou deixando de pensar, me concentro no sentir - ou o sentir me força a me concentrar nele. Sem falar, escrevo, não tanto quanto devo, não tão bem como preciso.

As palavras se pervertem: ora âncoras, ora faróis, iluminando o oceano nonsense de quem está só, à deriva.

Quando escrevo, leio e releio, é que venho à tona: lembro que existo. Tão simples quanto isso.

Aos poucos aprendo a escrever no escuro. O pulso encontra as palavras pelo tato. As luzinhas de Natal quase não iluminam o quarto, vão e vêm muito frágeis. Não vejo muito entre o sono, a falta de sono, as lágrimas - as primeiras depois de tanto.

É como se uma nova onda viesse e - sou jogada na costa novamente. Só resta levantar e andar, limpar as algas do corpo. Enxugar o cansaço, que cola a pele à areia. Mas espero. O cair da manhã, o sol e sua cegueira. O calor acordando o corpo. Portas e passos povoando a casa.

$\mathrm{Na}$ caixinha quatro, cinco comprimidos. Um deles sem marca de corte não me recordo do que é. Se for antialérgico, insônia. Taquicardia. Se calmante, ok. Comprimidos brancos me confundem.

Em menos de três meses no Brasil arrumei o trabalho dos sonhos numa editora especializada em poesia. Pela primeira vez, estou perto de onde sempre quis estar. Passo o dia lendo. Corrigindo. Lapidando as palavras dos outros, moldando as letras em frases mais certeiras, mais precisas, mais reais. E escrevendo. Mergulhando inteira naquelas palavras, pesquisando suas ressonâncias em mim, fazendo eco com outras metáforas. E durante todo o 
processo, milhões de ideias, anotações, insights sobre mim, os outros, minha escrita.

Imagino que o meu trabalho deve ser a descrição do inferno para a maior parte das pessoas.

- De onde você tirou esse termo? - pergunta o editor-chefe. - O que isso quer dizer?

- Eu: Ué, não é óbvio?

- Não. É um termo português?

- Talvez. Não sei. Pode ser... Quer dizer, se não é óbvio para você, é porque não é daqui.

- De repente é daqui e eu ainda não conheço.

- Tá... Mas não dá para entender, tenho que tirar?

- Não dá para entender. Vou tirar.

- Desculpa, de vez em quando me escapa alguma palavra...

- Mas você não sabe nem me dizer se é daqui ou de lá?

Tento estudar francês, mas só penso a estrutura e as palavras em alemão. Tento estudar/falar alemão, mas só me sai inglês. Tento falar inglês, mas penso antes em português ou alemão.

Tento falar/escrever em português lusitano mas escapam expressões e a estrutura do português do Brasil, num mix de sotaques frustrante. Falo português do Brasil e todos riem quando desliza uma frase, um termo do outro lado do Atlântico, que ficou no meu dicionário interno.

Reencontro uma amiga que também voltou de Lisboa para o Rio. Ela diz que é impossível esquecer o anoitecer de lá, o azul escuro no céu, luzes amarelas 
beijando o chão. Ela diz que não consegue, que quando o sol vai embora ainda espera aquele azul, que nunca mais. Que por isso preferia o sol, o dia, a semana, que aí não se lembrava tanto, que aí não precisava esquecer.

Eu digo que não quero esquecer.

Estimulada por uma amiga escritora e alguns colegas, junto meus contos para um primeiro livro. Foi o que sempre quis fazer: quando criança, além de escrever histórias, cortava as folhas e colava na sequência correta; não esquecia da ficha catalográfica (com um ISBN copiado de outro livro qualquer), nem do colofão. Meu primeiro sucesso em família se chamava Cláudia é médica; depois veio $O$ passarinho que falava português e $O$ Omem sapato (sem $\mathrm{H}$ mesmo). Curiosamente o único que restou de tantas mudanças. Espero não haver nenhuma piada cósmica nisso.

Procuro um novo apartamento, me disponho a dividir quartos, dormir em salas, o que for - só quero um espaço meu para poder me recolher quando não estiver aguentando mais o mundo. Mas no Rio de Janeiro, a bolha imobiliária torna essa necessidade básica num sonho quase impossível.

Me concentro na escrita do livro, o segundo agora; paro seis meses sem saber que rumo dar à história. Perco peso e leio vorazmente, me nutrindo de palavras. Meus pais se preocupam; sorrio e mantenho a postura. No final vai ficar tudo bem. As frases vão encher o papel em branco e a fome vai voltar, naturalmente. $\mathrm{Na}$ escrita como na vida, não há garantias: no precipício do papel em branco, prosseguir. Mesmo sem leitores, interlocutores, estímulo. Continuar marchando, mesmo que o esforço de uma vida vire comida para cupim.

Por que não me canso disso? Cada frase que escrevo rasga mais um arranhão na minha pele. Cada palavra subtraída, uma ferida que abre, sangrando feroz. Escrevo, reescrevo, risco e rabisco num círculo vicioso e interminável. Todos os dias penso que não é necessário, que já está bom - para no dia seguinte chorar de vergonha, de tanta imperfeição. Não sei por que essa ânsia continua, e mais uma vez me isolo ansiosa pelo momento de prazer, eu, o papel e a caneta, eu 
e esse eu-outro que pulsa e que desconheço e que me obriga a prosseguir. Não, a escrita nem sempre é arte nem refúgio; às vezes é automutilação.

\section{Fronteiras são cicatrizes}

na pele dos mapas

Uma amiga escritora me disse uma vez que são as histórias que nos encontram - tentamos esquecer, ou por preguiça, desânimo, medo, e elas nos perseguem e alcançam lá na frente, onde nunca poderíamos imaginar e por isso nos proteger. Não somos nós, são elas, elas é que insistem, nos rodeiam, surpreendendo-nos ou com um soco no queixo ou com uma rápida rasteira. Como quando estamos apaixonados e o nome da pessoa nos assombra em rótulos, letreiros, anúncios, menus. Parece que há uma inteligência qualquer a serviço do que tem que ser - parece Maktoub, ou que somos especiais, mas não tem nada a ver, é só isso: a história querendo nascer.

As histórias que eu mais gostei de contar só escrevi porque não conseguia mais fugir delas - porque não havia mais nada a fazer.

Uma das razões pelas quais demiti minha analista (há mais, claro): ela disse que se não fosse essa capacidade de sofrer e sentir, eu não conseguiria escrever.

Ora, é muito óbvio que se não fosse "essa capacidade" nunca precisaria escrever.

Porque a verdade é simples: passo pelas coisas sem perceber. Só quando escrevo elas ganham textura de real. Só quando escrevo me inscrevo nas cenas. O que se passa aqui dentro ou lá fora - só tenho acesso quando passa pelo meu pulso. Quando não tenho, as coisas pulsam muito de longe. Acenam distantes, num eterno aparecer-esquecer.

As coisas passam como se eternas em seus 15 minutos; eu assisto ao seu desaparecimento. Como elas assistem ao meu. 
Um dia, tragada pela angústia branca do papel, penso em desistir de procurar: se não sei qual é o final de uma história, por que inventar? Na vida não há essas respostas prontas (em um segundo tudo o que é certo pode mudar, drasticamente). Por que então tentar cravar de respostas, certezas e sentenças a literatura? Por que tentar ter controle, quando não se controla nem o país onde se quer viver?

\section{Para resistir.}

Resistir. Lembro do Aleksander Hemon, escritor bósnio-americano, um dos meus preferidos entre a nova leva de "escritores hifenizados". Em todos os seus livros que li (As fantasias de Pronek, O Projeto Lazarus ou O livro de minhas vidas), Hemon recolhe e dá voz a relatos pessoais e vivências seja de quem imigrou, seja de quem ficou e viveu a guerra na pele. Como se inventariasse os escombros de Sarajevo, dá voz aos exilados, imigrados e mortos, àqueles sem abrigo no passado de uma cidade até hoje marcada pela destruição. Porém, mesmo iluminando relatos de conterrâneos sem esperança no futuro e sem conexão com o presente, há algo bem maior do que a espetacularização de tragédias pessoais (buraco tão fácil de se cair ao falar de vidas alteradas por catástrofes). Há algo de resistência, de potência, de germinação latente, de movimentos súbitos e explosões inesperadas.

Essa potência está no humor irônico de Brik e Rora, protagonistas de $O$ projeto Lazarus, ou nas descrições das tentativas a princípio patéticas de adaptação dos personagens a uma cultura estranha. Nesse movimento, Hemon consegue capturar a imagem de uma guerra que o mundo assistiu pela tevê, resgatando a humanidade, com todas as suas particularidades, idiossincrasias e estranhezas por detrás do indivíduo, nesse caso, obrigado pelas circunstâncias a imigrar.

Algo que sempre me fisgou em seus textos é a capacidade de transpor para a escrita a sensação de identidade fragmentária e de alteridade vivida tanto pelo imigrante, como pelo escritor, que trafega entre o real e a ficção e se move no terreno desconhecido do papel. E, como desse lugar de alteridade pode surgir trauma, solidão, ruptura na identidade; e da fissura identitária e da fricção entre novas culturas, pode surgir pura potência criativa.

Sua própria obra é prova disso. 


\author{
Fronteiras são \\ fantasmas \\ somem na noite são \\ linhas \\ cercas \\ cicatrizes quando se curam, \\ coçam
}

Penso em Otto, o mendigo que mora nas redondezas. Na verdade nem sei por que o chamo de Otto se não sei o seu nome; mas ele tem cara de Otto, digo ao meu noivo. Você fala como se ele fosse um cachorro, ele alerta.

Otto dorme todas as noites nos fundos de uma garagem, e usa sempre o mesmo pulôver verde-escuro e uma bermuda - que já foi jeans - meio rasgada. Não recebe doações de roupa, comida, não bebe. Uma vez ou outra aceita cigarros.

Todos os dias nos cumprimentamos - ele muitas vezes está de pé, apoiado ao muro da escola, no horário em que passeio com minha cachorra. Sempre nos falamos bom-dia. Às vezes, é o único que recebo durante a semana tirando saudações automáticas de porteiros e garçons, claro.

Otto raramente tem os olhos perdidos. Sentado no paralelepípedo, alimenta com não sei o quê os pombos, que o rodeiam como se ele fosse uma estátua. Sempre que passo por ele tento pisar de leve no chão, evitando que os pombos se assustem e voem. Afinal, eles são sua única companhia.

Sempre que me dá bom-dia, Otto me olha diretamente nos olhos. Há qualquer coisa de alegria por baixo das camadas de roupa, cobertor e sujeira em que se esconde. Há qualquer ferida, sim, mas também há uma insistência enorme. De repetir os mesmos gestos todos os dias. De ocupar aquela esquina. De se rodear de pombos e fazer com que pedestres mudem de calçada, com nojo dos pássaros - ou do quadro inteiro. Mas nós também repetimos os mesmos gestos diariamente, insistimos em ocupar algum espaço; às vezes, nos contentamos com prazeres tão sem sentido quanto comprar o celular mais caro, gastar um salário 
mínimo num jantar, ganhar mais um like nas redes sociais; à noite, adormecemos vendo séries em streaming. Nossa insistência em existir nessa gratuidade é assustadora. Deveríamos desistir, ou pelo menos, não nos esforçar tanto para parecermos bem. Talvez assim pudéssemos fruir de prazeres simples, mais diretos - talvez não precisássemos de tanto a toda hora.

Ao contrário de mim, meu irmão escolheu uma carreira segura e de sucesso. Casou com a mulher por quem era apaixonado há anos e tem dinheiro suficiente para ir ao Coachella, Primavera Sound System, enfim, aos melhores festivais de música do planeta. Mas como todo conto de fadas, há um porém: de três em três anos, tem que mudar de país. A vida cheia de aventura e conforto que instiga a cobiça em tantos amigos só me faz doer o coração ao pensar nas crianças - que terão de mudar de língua, escola, terra ao longo da infância inteira.

O mais curioso é que Rafael sempre detestou viajar de avião. E ainda há a cereja no bolo do humor negro divino: nunca gostou de Portugal - achava um saco aquele país antiquado onde até um McDonald's era difícil de encontrar.

Ele estava cotado para trabalhar em Istambul, Madri ou Chile. Um dia acordei com a certeza de que não era nenhuma delas: era Lisboa. Liguei para minha mãe e avisei: seu filho vai para Lisboa, a mulher dele vai engravidar lá e seu neto será português. Mas é impossível, meus pais replicaram; nem existe essa hipótese. Bom, dito e feito; meses depois abria uma vaga na embaixada, e o casal se mudava para a rua das Janelas Verdes. Uma das mais emblemáticas da cidade.

Os dois exames, curiosamente, foram muito próximos. Primeiro, o PetScam do meu pai. O diagnóstico confirma o câncer, e eu perco o chão. Num arrastado silêncio Rafael me ouve chorar ao telefone: Papai vai morrer um dia, mas não agora, garante. Minha mãe não derrama uma lágrima, mas mal consegue mover o pescoço de tanta dor na cervical. 
Na véspera da operação, uma imagem no celular faz meus pais chorarem e eu também, convulsivamente, no trabalho. Uma pequena ervilha ou feijãozinho pulsando com vida e, como num milagre, cobrindo o medo e a dor com uma inexplicável alegria.

Era a primeira ultrassonografia da Abigail. Eles esperaram três meses para dar a notícia; meu pai entrou para a sala de operação já sabendo que seria avô. E que sua netinha seria, como ele, portuguesa.

No hospital, meu pai só come líquidos; durmo na cama ao lado e tento entretê-lo com livros e séries de tevê, enquanto faço um copidesque de uma tradução sofrível de uma publicação médica. Ele opera os intestinos; estou no capítulo oito do manual de anatomia cirúrgica, dedicado aos rins. Às $21 \mathrm{~h}$ meu pai pede para apagar a luz; levo as almofadas para o banheiro e improviso uma poltrona - não posso dormir porque ele pode precisar de mim; aliás, nunca conseguiria dormir. O quarto cheira a urina e faço piadas na hora de limpar o recipiente de mijo, para aliviar o desconforto. Meu irmão está perto - liga sempre - mas está tão longe lá em Lisboa. Tão longe com sua mulher grávida, casa, carreira internacional.

De madrugada não resisto e desço para o jardim do hospital. Pego um cappuccino e enxugo as lágrimas; pensei que nada podia doer mais do que perder Lisboa e agora parecia que o chão se abria e o céu me esmagava com total indiferença. Pego o telefone, mas é muito tarde para ligar para alguém; insisto e passo os olhos pelos contatos, mas só aparecem números de farmácias, colegas de trabalho, médicos - não há ninguém para ligar. Cheguei há seis anos no Brasil, mas é como se fosse ontem.

Um rapaz se aproxima e vem fumar ao meu lado, e eu aceito quando ele me oferece um Marlboro vermelho. O sabor é horrível, mas o contato dos dedos e dos olhos dele com os meus traz um senso de realidade, e a fumaça enchendo os pulmões acalma, desafiando o nó na garganta.

Só a notícia da gravidez traz algum alento nessas horas intermináveis de operação e recuperação. 
Quando éramos crianças, meu pai levava Rafa e eu todos os domingos de manhã para o hospital onde trabalhava. O mesmo onde eu nasci, o mesmo onde minha avó materna morreu; o mesmo onde seu tumor é operado, agora. Lembro que meu irmão adorava descer e subir as rampas, pular nos sofás da recepção, e sempre levava bronca das freiras (o hospital é católico). Nunca dei trabalho; sempre levava um livro que preenchia as horas, enquanto esperávamos o ápice do dia: a ida a cantina, onde a dona Micas nos deixava pegar os doces que quiséssemos - meu pai pagava depois.

Mas a minha principal lembrança é de brincar sozinha no jardim, perto da recepção.

Lembro de seguir com os dedos os caminhos das formigas e conversar com cada planta; cada uma tinha nome e personalidade próprias - eu sabia as histórias de vida delas e traduzia para outras mais verossímeis para o mundo, ou achava que sim. Era o melhor momento da semana, esse em que eu passava criando histórias com as plantas, naquele jardim.

Hoje, depois de passar de novo a noite no hospital com ele, fui descendo a rampa do segundo andar e quando vi já estava no jardim. Mas ele não era o mesmo. Não há mais rosas nem Maria-sem-vergonha, não vi formigas nem risos de outras crianças - só eu, uma nesga de sol, arbustos sem flor.

Mas essa flor vermelha, surgindo espontânea no verde, já me disse tudo.

Meu corpo mudou, minha vida mudou.

Aqui dentro, as flores e eu somos sempre as mesmas.

\section{6.}

Era isso que trazíamos em nossas viagens pelos oceanos, atravessando fronteiras, passando pela vida: nosso pequeno armazém de anedotas e do que aconteceu depois, nosso era-umavez pessoais. Éramos nossas histórias e quando morríamos, com sorte, nossa imortalidade estaria em uma dessas histórias. Essa era a grande verdade contra a qual Malik Solanka havia se colocado. 
Era precisamente sua história pregressa que ele queria destruir. Não importa de onde ele viera, nem quem, quando o pequeno Malik mal sabia andar, havia abandonado sua mãe e assim lhe dado permissão, anos depois, para fazer o mesmo.(...) Tinha vindo à América como tantos antes dele para receber a bênção de passar pela Ilha Ellis, de começar de novo. Me dê um nome, América, faça de mim um Buzz ou Chip ou Spike. Mergulhe-me em amnésia e me vista em seu poderoso desconhecimento. Me aliste na sua J. Crew e me dê minhas orelhas de rato! Não mais um historiador, mas um homem sem histórias me permita ser. Arranco da garganta minha língua-mãe e falo o seu inglês torto no lugar.

RUSHDIE (2003, p. 65).

A resposta mais natural para um emigrante que se sente humilhado pelos nativos talvez fosse a revolta, mas uma revolta aqui só cabe debaixo dos panos pela fuga, pelo evitamento, pela recusa silenciosa em fazer parte do jogo. Recusando alimento, recusando pátrias, recusando amor. Assim seria impossível ser apanhado; ou pelo menos, difícil.

Após anos treinando a invisibilidade, confirmo o sucesso dessa estratégia ao entreouvir uma conversa do meu pai, que confessa ao meu noivo a verdadeira razão de ter largado a faculdade a meio no Porto e voltado para o Brasil. Claro que tinha saudades dos pais, do Rio, mas...o Porto era uma cidade pequena, porém cheia de estudantes, bares e vinhos - como futuro médico, já tinha um passaporte para pertencer à elite.

Decidiu voltar quando ouviu um vizinho, que voltava da guerra em Moçambique para o Natal com a família. O senhor, já aposentado, contou horrores sobre a luta na colônia Aafricana. Foi só acabar o Natal para ser chamado de volta ao campo de batalha. Meu pai era jovem, sem doenças nos olhos ou pulmões, ou seja, um candidato perfeito para ser convocado; mais valia jogar para o alto seus privilégios futuros de médico português e desapontar os pais do que acabar numa vala qualquer debaixo do sol quente africano, em nome de uma guerra que nem era sua.

Fugir do conflito, sempre. Se esconder ou se camuflar - o predador à espreita, mas enquanto pudermos evitá-lo, não nos colocaremos na frente do canhão. 
Anos treinando a invisibilidade; tal como minha tia, tal como minha avó - cada vez fazendo menos segredo de suas questões com a comida devido à demência. Viveu anos fora do radar; também deve ter pensado que seria impossível apanhá-la; que assim teria mais chances de adiar a captura. Desaparecendo aos poucos como forma de autopreservação.

Poderíamos fugir, nos fazer de mortos, nos preservar. O jogo poderia estar ganho se. Se não fosse o câncer dele. Se não fosse o meu desmaio, o sangue jorrando sem dor no chão - a cabeça é muito irrigada, explicaram. Se não fosse o telefonema - e a notícia de que ela se foi.

M. não deixou bilhete, não pediu ajuda, mergulhada no poço escuro de si, ela própria a coruja que se afoga, antecipando as mãos do predador. Era a semana do meu aniversário, amigos conseguiram esconder o fato por uns dias; quando soube, entendi logo, depois não acreditei mais, depois não entendi nada.

A linha entre invisibilidade, desaparecimento e inscrição são difusas, confusas, invertendo-se quando menos se espera. O jogo agora parecia ainda mais perverso - há quem não aguente a angústia e os fantasmas da espera, há quem não tolere a indignidade de aguardar o destino se abater; há quem vire a mesa e derrube o tabuleiro.

De repente todas as peças mudam de lugar.

Remédios não trazem mais o sono. As horas são uma sequência de tarefas e etapas que levam uma a outra, como uma gincana em que perco ao não me levantar a tempo para o café, para a aula, para a hora do remédio, do banho, das compras. A cachorra late e urina pela casa; pessoas entram e saem com pratos de comida que aceito - não há mais por que não comer. Não há por que resistir: o jogo acabou. O contato com humanos se resume a pedidos de delivery via internet, ou à compra constrangida de tarja-pretas na farmácia. As roupas não 
cabem, então deixo de usá-las - os livros ocupam a cama e empurro o computador para o travesseiro ao lado, esticando o corpo enrolado no pijama.

É noite; as pessoas dormem, as estrelas piscam um SOS num tempo que já foi - cadáveres pedindo anacronicamente ajuda. Para não ver mais nada, fecho os olhos; para não ouvir a vizinha senil àquela hora na portaria, conversando com o porteiro de camisola; para esquecer Russo, que vaga sozinho e vez por outra pede cinco reais pra uma latinha, sumindo no bar famoso pela sua pinga e pó, ou o senhor que comprava bavárias às 8 da manhã e bebia com os mendigos e um dia desapareceu para nunca mais; ou Otto, que divide a quentinha com os pombos e hoje de manhã estava com um olhar ainda mais alerta na calçada. Todos exilados em sua bolha que ninguém ousa estourar por medo - da visão, do contágio -, todos perdidos.

Será que era assim que ela se sentia?

Fecho os olhos e espero pela luz diurna, os barulhos de portas e panelas prometendo alguma trégua no absurdo disso tudo. Depois de três dias e noites já não tento ir à aula, vestir roupas, tomar banho; apenas folheio livros e rabisco linhas curvas que se encontram num ponto ao centro. Reúno cadernos e cadernos com o mesmo desenho que me persegue como a flutuação das águas do poço, rabisco e rasuro para aguentar até o próximo por do sol, com seu pedido inútil de ajuda das estrelas.

Como você consegue?, ela dizia no e-mail.

Quer saber, sei lá. Eu nem sei por que eu estou aqui sentada escrevendo isso aqui. Você já impôs essa distância enorme que eu confesso, nem sempre consigo respeitar mas não tenho sido (de novo, creio, por que nunca dá pra saber) fonte de incômodo. É como se eu nem pudesse ficar feliz por você, por nada que seja relativo a você. 
Acho realmente que nunca vou entender a sua aversão a trocar algumas palavras comigo ou qualquer coisa, qualquer coisa mesmo. Gostaria de entender mas acho que não consigo, por mais que eu pense, não consigo.

Mas deve ser assim mesmo, as pessoas não devem conseguir ser capaz de enxergarem o próprio teor nocivo. É realmente uma pena. Não tudo, quase tudo. Esse depois.

Esse depois inexistente, essa minha presença que nem existe mas que não deixa de ser incômoda, essa necessidade de me cortar. Lembro de você ter mencionado certa vez não ser capaz de trocar de botões, ligar ou desligar algo. Talvez tenha se enganado. Quando finalmente conseguiu, apertou o botão de desligar.

\section{E é claro que você tem todo o direito.}

Acho que eu devo sentir saudades de uma amiga que achei que tive e que não existe. Leio coisas que nos escrevemos, conversas nossas e coisas que não têm nem a ver com um "nós", e eu não sei onde aquela C. foi parar. Não sei por que aquela $C$. deixou de gostar de qualquer coisa que tenha relação comigo. Ou eu realmente devo ter sido uma $M$. diferente demais e nem notei.

Não respondi. Era só mais uma das muitas vezes em que ela aparecia me perturbando, deixando comentários em blogs, furando o bloqueio de redes sociais, enviando fotos estranhas, dicas de leitura, comentários sobre meus posts, ELA sempre falando DELA e mijando no terreno, primeiro batendo à porta, depois jogando ovos para que eu ao menos olhasse pela janela. Eu me recuso - ela se cansa. Achava eu. Agora releio seus e-mails e a cada minuto gifs animados me invadem em flashes de luz: no céu dos olhos, imagens em alta rotação do seu rosto sorrindo, o jeito de prender a mecha escura atrás da orelha, suas palavras me assombrando até no sono. Quantos dias para as imagens se diluírem num filtro early bird de Instagram, distante? Quantas semanas, meses, anos, quantas tardes perdidas ainda, noites caladas olhando fotografias, tentando imaginar como seria, o que poderia ter sido. Era pior à noite, antes de adormecer - ou ao acordar, a semiconsciência durando segundos até o soco no estômago e a náusea de reviver a dor da perda no minuto após o despertar, todas as manhãs. E ao longo dos dias carregar a pedra monte acima; só para vê-la deslizar de volta ao mesmo ponto 
doloroso de partida ao toque do despertador. Acordar sozinha, eu, as imagens e os cabelos emaranhados como as ideias, enegrecendo o travesseiro.

Relia mensagens, e-mails, cartões-postais. Como se pudesse e tivesse que fazer alguma coisa - como se já não fosse tarde demais. Dois meses antes mensagens como essa apareciam no meu inbox:

Não estou escrevendo por capricho ou porque eu acho que quero porque quero você perto. Não é nada disso. Existem poucas pessoas que entendem certas coisas. Existem poucas pessoas que passaram por certas coisas e você é uma delas. Eu não pediria ajuda justamente a quem não fala comigo se não fosse crucial.

$\hat{E}$.

Pela primeira vez em anos pensei em voltar ao hospital ou acabar com tudo antes disso. Fazia tempo que isso não acontecia. Mais de dois anos. Entendo que você tenha que ser sincera e não possa se envolver e nem estou colocando nada nas suas costas. Você está certa. Aliás, de tempos pra cá, tenho dito: está certa. Você cresceu e eu diminuí e não sei com quem contar. Como contar com gente que não entende o que é isso?

Covardia minha; paralisia total; meus amigos diziam que ela era tóxica, que eu tinha que me afastar, me proteger. Os mesmos que desapareceram durante a primeira quimioterapia do meu pai, o que deve querer dizer alguma coisa.

Gente que não entende o que é isso.

Minha principal leitora/interlocutora/stalker resolveu ir embora. Não da minha vida; desse mundo. Isso depois de muitas ameaças, pedidos de ajuda, posts de autocomiseração que só faziam com que todos perdessem a paciência. Ela era over, tóxica, sempre mal, so needy and clingy. Como se eu não tivesse minhas questões e dificuldades. Como se ninguém tivesse. As pessoas são muito egoístas, que invasivo isso de jogar esse abacaxi para você, comentava um amigo.

Assim que recebi a notícia, foi ladeira abaixo: minha produção caiu $80 \%$. Até hoje não é o mesmo; o processo, a vontade de escrita, a fé no escrever como forma de viver plenamente. 
A escrita deixou de ser um porto seguro. Parece mais um fardo ou fado que carregamos porque não temos outra escolha.

Uma parte nossa morre com a gente quando partimos. Há outra que também morre quando alguém inesperadamente parte. Partida ao meio ela se foi, abrindo um fosso dentro de todos nós. Os que ficamos.

Um dia eu cheguei na Prefácio e você já estava lá dentro e não me viu. Fiquei uns instantes a te olhar. Você folheava um livro de maneira serena porém levemente desconcertada. Você frequenta bastante aquele lugar mas nunca vi entrar lá como se ele lhe pertencesse. Parece que nenhum lugar lhe pertence, nem você mesma, parece que - e isso baseia-se só no que vi, vi de você e não li, que você nunca está confortável com nada.

Lavo a louça, tomo um banho quente, reviso maquinalmente um livro sobre sustentabilidade para crianças - as mensagens ecoam no background do meu cérebro. Não consigo parar. Pará-las - as frases.

Às vezes sonho que estou escrevendo, ou cantando, e no próprio sonho penso em pegar o caderno e anotar a música/versos. Mas quando abro os olhos as palavras e notas escapam à luz do sol. O caderno está longe na estante, vazio. A escrita se deu no sonho, e o sonho se diluiu como as gotas de Clonazepam debaixo da língua.

Pointless. É o termo certo, que ela sabia tão bem usar. Freio o pulso, a caneta; me refugio em leituras, tenho muito, muito cuidado com qualquer gesto que possa destruir o precário equilíbrio em que vivemos.

Um respiro e alguém se joga de um prédio. Um pé mal posicionado no degrau e caio rolando de uma escada; o condomínio sobe de novo, o câncer retorna. Do nada aparecem pulgas na cachorra e morro em uns 300 reais de remédio e dedetização; a cirurgia estava marcada para julho e já é novembro—não faço mais ideia do tamanho do tumor da bichinha. 
Um espreguiçar desatento e ele acorda triste e eu não consigo devolver seu sorriso; fiz alguma coisa e alguém está chateadíssimo e não faço ideia do que foi; meu corpo perde o controle; perco aulas, consultas, sono, fome.

Vejo o sol nascendo, diariamente, enquanto a casa ressona ao meu redor. $\mathrm{O}$ astro subindo pálido perto do Cristo, enquanto a última estrela resiste ao azul ciano. Conto as moedas para o ônibus; parto em quatro pedacinhos o remédio que vai acabar antes que o dinheiro dos frilas chegue.

Vejo o tempo que passa. O tempo que ela congelou na hora certa. Não escrevo. Não há por quê. Só aceito encomendas. Escrever de verdade, para quê? Para quem?

Isso vai passar, dizem. É só um writer's block. É uma questão de ajuste fino de medicação. De conjuntura astral. De estresse, falta de magnésio. Em vez de ficar melancólica, fico irritada, o copo cheio-e infelizmente não é de gim nem de vodka. Irritada com as eleições norte-americanas, com a alta do dólar, com as fronteiras, com o horário dos supermercados, dos bancos; com a quantidade de pessoas na rua; com o fato de morar no Brasil e não poder passar a tarde sozinha num café observando as pessoas - sem ser alvo de olhares de pena ou interesse.

Examino as linhas do nariz, queixo, boca. Confirmo - a franja castanha torta, as olheiras roxas, o sinal perto dos olhos. Então ainda estou aqui, sou eu mesma, constato, num misto de alívio e pânico que dura meio segundo - na outra metade, lembro de cada esbarrão na rua na última semana. $\mathrm{O}$ telefone que não toca, não vibra, não se ilumina há tantos dias que nem sei, a caixa de e-mails que só recebe spams, a cadeira ocupada no trabalho, a geladeira vazia. A bicicleta que quase me atropelou, a moça do café, que continua de costas para o balcão, mesmo que eu levante a voz ao fazer o pedido. $\mathrm{O}$ meu nome, que nunca mais ouvi.

Junto todos os dados do real ao reflexo no espelho, e duvido.

Será que ela sabia? Quando saltou para a invisibilidade sem volta, sabia que estaria se inscrevendo para sempre na nossa história, retornando num eterno loop, interferindo em ideias, sonhos, conversas - em todas as histórias que escrevo? Será este o único jeito de escapar do fim inevitável - atirar-se 
inesperadamente a ele e assim vencer o jogo? Será esta a fórmula mágica para viver para sempre, enquanto a nossa memória durar?

- Sonhei que estava no quarto dela e ela separava as coisas que ia deixar para cada um quando fosse embora

- acho que entendeste

acho que estamos a falar de uma pessoa altamente desequilibrada

que te assediava e perseguia

(sem conseguir ser doutro modo, certo)

e por isso é que tentaste cortar contacto

que é aliás

o que devias ter feito

acho que tens razão em estar triste

devastada até

mas assim

dores no corpo e tal

caramba, estás viva

Às vezes parece que te esqueces dessa parte;)

O toque de despertar é o som dos cigarras; ao primeiro zzzzzz as costas coladas à terra começam a pinicar, como se formigas gigantes ganhassem vida.

Não são formigas, são traças, descubro horrorizada.

Finalmente sei onde elas se escondem da fúria solar até que a luz do dia derreta no horizonte e elas possam sair, sem medo, à caça de ondas sonoras noturnas. Ondas navegáveis. Luzes domesticadas, previsíveis. Não têm a coragem-ou desespero-de Ícaro. Mas a pulsão de morte é a mesma-já sabemos seu fim. Like a moth to a flame. That's the way love goes. Jane Austen? Não. Janet Jackson.

[Filosofar à toa sobre o destino das mariposas em vez de pensar com elas. Essa caprichosa e inútil humanidade.]

Mas sim, caprichosa e inútil, sigo; pois agora sei onde se escondem. Dormem debaixo da terra o dia inteiro à espera, à espreita, esmagadas por nossos 
corpos, pálidos distraídos em toalhas quadriculadas de piquenique. Agora que sei de tudo fico mais atenta. Mais alerta. Sento na grama com respeito, observo suas asas castanhas cor de troncos, a mancha escura em cada asa como um grande olhar negro que atrai e repele o humano com seu campo magnético. Deve ser uma mutação qualquer para afastar predadores - há mais predadores de traças do que de homens? Sim, talvez sapos, lagartixas. Estremeço ao pensar em mais bichos.

A culpa não é das cigarras, dos maus inseticidas, das larvas e mariposasa culpa é da ambição dos homens, vendendo lofts e coberturas no antes habitat natural dessas "pragas", construindo parques civilizadamente arborizados para o conforto dos novos moradores. Ou a culpa é dos insetos, que não sabem ficar no seu devido lugar - o escuro subterrâneo.

Como saber onde é o seu devido lugar? E como permanecer lá, meu deus?

O som das cigarras dói nos ouvidos—as traças não fazem mal nenhum, minha tia-avó dizia, quando eu era pequena e me protegia atrás das cortinas do voo alucinado dos insetos alados ao redor das velas. Elas se agarram nos fios de cabelo e podem entrar no cérebro pelos ouvidos, escreveu um professor na coluna de jornal, dando os primeiros sinais públicos de insanidade. Verdade ou mentira, o que sei é que são bichos covardes; só saem à noite, como morcegos, marginais, deprimidos, pessoas com encosto, viciados; fracos, sabem que não resistem à retidão do dia, ao governo do sol.

Muitos de nós também não resistimos e nem por isso somos expulsos do mundo com aerossóis de raid, certo? Se bem que às vezes usem spray de pimenta.

Agora são elas que nos expulsam dos parques arborizados, cada canteiro milimetricamente distante um do outro, ambiente saudável para crianças caírem e levantarem - sem lama, sem terra fértil, sem o caos da vida. É tudo muito lento e gradual até que acelera de repente: pontinhos cinzentos se destacam no chão verde do parque e elas renascem, enquanto o sol desmaia no horizonte.

Quero ir embora sem ver nada, mas permaneço colada à terra, olhos vidrados como se assistisse a um acidente na estrada. Tenho medo da decolagem do bando, das intenções escusas daqueles olhos secos; as primeiras estrelas surgem no céu, finalmente escurece e elas irão embora à procura da luz elétrica, elas nos deixarão em paz. Olho os brilhantes no veludo do céu e testemunho o voo coletivo com mais calma - as traças partem em grupos de três, quatro, viagem coreografada 
como se abduzidas por uma missão, um chamado a que não podem dizer não. Uma missão suicida.

Lepidópteros - era assim que Pessoa e Sá Carneiro apelidavam burgueses e artistas que viviam mais da atitude que da arte, passando mais tempo em busca de aplausos do que produzindo efetivamente. Mas isso não seria também uma arte performática, pergunto eu?, sou exceção, evito pessoas, imagine plateias. Minha opinião não vale aqui. Lá também não. Vou pensando nisso enquanto subo no elevador, abro a porta e chego a casa. Tento fechar as janelas mas já é tarde; elas invadiram mais uma vez a sala, rodeando o lustre no seu voo maníaco. Anseiam pelo que lhes faz cair, como os cracudos do bar ali da esquina; já não é uma questão de prazer, mas de não ter o que fazer pra driblar a fissura. A luz talvez nem seja mais êxtase, só alívio da dor - talvez elas passem o dia debaixo da terra não para ficarem de "bote" mas só para suportar a abstinência, até a hora que a próxima dose for possível.

Difícil imaginar que dançar em torno da luz seja tão embriagante que pouco importa cair ao chão e perder as asas depois do êxtase. Será que as mariposas sabem que é esse o seu fim? Ou será que elas são programadas, brainwashed como kamikases que sabem que é essa a sua função e mesmo assim preferem morrer pela luz do que viver, como nós, na escuridão do pecado?

Lá de onde venho elas são chamadas só de traças. Aqui as pessoas chamam de mariposas. Quando mostro fotos ou as descrevo as pessoas dizem que é a mesma coisa mas eu sei que não-mariposas não andam em bando. Vêm sozinhas e se colam nas paredes, as asas de veludo negro e as antenas balançando como o ponteiro de um relógio contando o tempo. O que nos resta.

Um dia acordei com uma mariposa morcega pousada no travesseiro ao meu lado, zelando meu sono. Nesse dia ela ligou, discutimos. Toda vez que o inseto de asas negras aparecia ela ligava ou mandava algum e-mail, e por isso passei a ter pânico de mariposas - medo, asco, horror. Elas se alimentam da nossa luz, elas nos roubam tudo e nos deixam vazios. Da última vez que uma entrou aqui 
em casa, chorei. Era ela de volta, no céu ou no inferno avisando que estava por perto, que estaria sempre. Só que não haveria e-mail, não haveria telefone - ela já havia sido sugada pela fome, fé e fogo, abatida ao chão - como um homembomba, matando todos nós com sua tristeza e raiva.

Russo reapareceu, confirmo com alívio, vendo ao longe sua silhueta disforme (a barriga inchada em braços e pernas finas) sentada nos degraus do boteco habitual. Uma ou duas semanas desaparecido? Com a doença do meu pai, posso simplesmente não o ter visto por aí. Dessa vez, voltou com um olhar catatônico, concentrado no fundo do copo de café. Nem me aproximei - não parecia querer conversa.

$\mathrm{Na}$ última vez em que lhe dei um cigarro ele estava superelétrico, com tiques estranhos na sobrancelha e maxilar, o que dificultava a leitura do seu rosto. Mas os olhos e pupilas enormes piscavam como a boca que não parava de falar frases soltas sem sentido - entre máximas deleuzianas e anúncios de um novo profeta. As pessoas desviam do seu corpo sentado no degrau, mas nunca tive medo; alguma coisa naquele andar sem rumo é muito familiar.

Flusser (Russo é obcecada pelo escritor, ainda mais quando está falante) explica como aquele que não tem pátria, o estrangeiro, o de fora, incomoda os habitantes da clausura protetora da Heimat, pátria: revela como tudo aquilo que confortavelmente acreditamos como as verdades mais "originárias, únicas e inimitáveis" - ou seja, tudo o que a nossa ideia de pátria mãe significa - pode ser questionado ou mimetizado.

"O estrangeiro, para falarmos de um modo que recorda a Genealogia da Moral, de Nietzsche, revela que a Heimat é um constructo de hábitos decantados, cristalizados, cuja origem foi esquecida. Ele profana e dessacraliza a Heimat. Ele mostra como as regras da Heimat são banais" (FLUSSER, 1992, p. 253). Como consequência, ele é ainda mais odiado ou estigmatizado. Ou, como continua o pensador, "é apontado como o 'outro' do próprio", "feio e digno de ser odiado" (FLUSSER, 2007, p. 254).

"Narciso acha feio o que não é espelho.”, já dizia Caetano. Mas, nessa 
lógica, ele teria horror a quem lhe devolvesse uma face interrogativa - ou expusesse suas rugas, cicatrizes e feridas na superfície reflexiva. Desviaria o trajeto, viraria a cara ao ser interpelado - mudaria de calçada para evitá-lo.

Será que, sóbrio, Russo sabe que Flusser fala por ele?

No início pensava que era loucura, um sexto sentido qualquer - esta hipersensibilidade olfativa -, mas cheguei à conclusão que é tão normal quanto para outras pessoas é simples decorar e distinguir marcas de carros. De repente o cheiro começou a me fazer mal. O cheiro da doença. Que eu sinto assim que entro no carro, na casa, que abraço seus ombros curvados. É uma mistura de cheiro de asilo, hospital, urina humana e mais algum elemento específico que não consigo decifrar. Um daqueles elementos químicos que bombeiam suas veias, células, sistemas de quinta a domingo. Às vezes é insuportável, penso que vou vomitar saio da mesa e alivio o choro no banheiro, a água gelada acalmando os olhos vermelhos. Meu noivo e eu trocamos olhares e seus olhos me abraçam da cadeira ao lado. Sua mão aperta a minha debaixo mesa, vai ficar tudo bem.

"Não tenho culpa se ela perguntou o que eu achava; eu não liguei pra ela, não liguei pra ninguém, não fiz posts dramáticos nas redes sociais, estou quieta. Mas se me perguntam como ele está, e se a pergunta não for só por educação, ah, aí vou dizer a verdade."

"Mas você assusta as pessoas à toa, seu pai está ótimo", ela diz. Sim. Como a cachorra está ótima, operar é bobagem - o tumor é minimal, do tamanho de um grão de arroz.

Um grão de arroz a mais para o lado, que empurro para o canto do prato, como com 12, 24, 32 anos, quando médicos sugeriam internação, "mas pra quê, ela está ótima! Está melhor em casa. Sem médicos e outros pacientes. É só comer um pouquinho. Vou colocar ovo na sopa, nem vai perceber. É fase, doutora, ela sempre tem isso, depois passa. Minha filha, você sabe o que é um hospital 
psiquiátrico? É um lugar para drogados, esquizos, não pra você. Você trabalha, estuda, vai casar, você é normal, só tem que parar com o drama, nenhum homem aguenta tanto tempo. Uma coisa dessas fica pra sempre no currículo, sabia?" Minha senhora, sua filha não dorme mais de duas horas, esquece de comer, só sai de casa para comprar comida pra cachorra, café pra acordar ou vodka pra dormir. "Todo mundo tem problemas, olha a fulana..." Fulana não pesa x quilos, interrompe mais uma vez a médica, e eu lhe faço sinal com as mãos pra desistir. A porta está fechada. Sempre estará.

É tudo uma questão de ponto de vista. Eles veem o conjunto e a floresta inteira, de longe - alguns pontos queimados, uma e outra árvore caída, mas, no grosso, a floresta está de pé, cada raiz se comunicando com o solo e transformando calor pela fotossíntese. O conjunto é verde, vivo, vibrante. Um pouquinho menos que antes, mas já era esperado, não?

Digo que não aguento mais. Ele sugere uma nova medicação - não quero, não faz sentido tentar. É cansativo demais, explico. Ele pergunta qual seria a solução e eu digo "voltar para casa, ora" - como qualquer criança deixaria escapar. Tem certeza? Não, claro que não tenho certeza. Sou adulta, as certezas ficaram lá atrás, na adolescência.

Se for embora, nada lá me espera. Terei que começar tudo de novo novos tropeços, tentativas, erros -, mas ao menos não haverá plateia, penso. Posso acordar ou não; tanto faz. Posso trabalhar num café, viver num quarto de pensão, escrever só pelo prazer e necessidade; tentar uma vida mais simples, sem tantas metas e ambições que nem são minhas. E há minha sobrinha, a chance de vê-la crescer dia a dia. Talvez com o tempo até apareça a vontade de, aos poucos, acordar.

Mas se eu for embora, será a segunda cidade que perco. Ou a terceira; a segunda vez que perco a mesma cidade, que nunca foi nem será a mesma.

Mas o essencial é o foco na perda. Por que me sinto um mausoléu de cidades? Carrego comigo os cacos do que sobrou do naufrágio, do incêndio, dos desastres naturais ou não. Minha bolsa pesa nas costas, não consigo largá-la. A 
cortina pink da casa de lá, a vista do Cristo da casa daqui; os colegas de faculdade de lá; os amigos de escola e de mestrado daqui. Meu irmão lá. Meus pais e futuro marido aqui. Eu no meio em lugar nenhum: não sou capaz de abandonar nada.

Sinto o profundo desamparo das coisas esquecidas. E essa dor dos objetos - o casaco no chão, os pratos sujos, os sapatos espalhados pela casa que não consegui arrumar, não tenho estômago para abandoná-los. Mil vezes o peso nos ombros. Mil vezes.

Nos últimos dias não tenho falado com Russo, que ainda parece fora do ar - provavelmente Quetiapina, Depakone ou Haldol mesmo, algo que lhe dão em algum hospital em que é atendido (espero eu). Mas da última vez que o vi passar, a novidade era o terço de contas de madeira pendurado no pescoço.

\begin{abstract}
Não pertencer a nenhum lugar, nenhum tempo, nenhum amor. A origem perdida o enraizamento impossível, a memória imergente, o presente em suspenso. $\mathrm{O}$ espaço do estrangeiro é um trem em marcha, um avião em pleno ar, a própria transição que exclui a parada. Pontos de referência, nada mais. O seu tempo? O de uma ressurreição que se lembra da morte e do antes, mas perde a glória do estar além; somente a impressão de um sursis, de ter escapado. (KRISTEVA, 1994, p. 15)
\end{abstract}

Flusser espanta qualquer melancolia, sussurrando o quanto de liberdade existe nesse "enraizamento impossível".

"Não somos plantas - ser fiel às próprias raízes é superá-las. Nosso estar no mundo é marcado pelo fluxo - fliessen - e não por sermos seres estáticos plantados em culturas estáticas." (FLUSSER apud SELIGMANN-SILVA, 2010a, p. $5)$.

Influenciada por Russo - sim, meu vizinho de bairro esquizofrênico me influencia -, acabo comprando os Diários de Flusser (em original, Bodenlos) e descobrindo o que viria a ser chamado, posteriormente, de Filosofia positiva do exílio. Positiva porque Flusser tira o exilado do lugar de vítima para o de modelo - de vanguarda, novo homem. Se a nossa pátria molda nossa visão de mundo, ou, 
como diz o autor, é a nossa "matriz de pensamento", romper com ela é cair no vazio.

É previsível que Flusser, que viveu em quatro países e se comunicava fluentemente em pelo menos quatro línguas, só poderia ter uma visão positiva da imigração e do nomadismo em que vivia - de outro modo sua narrativa de vida não teria um sentido. Claro, há pessoas que vivem sem se guiar por um propósito, mas para insistir em sobreviver a guerras, perseguições, e manter (ou inventar) a vontade de conhecer e aprender novos hábitos em outras pátrias, é preciso algum horizonte positivo de vida. Minha avó, que vive há mais de 60 anos no Brasil, nunca perdeu o sotaque; durante quarenta anos viajou todos os anos de volta para a Terra natal; sua casa é um memorial de galos de Barcelos, nossa senhoras de fátimas ora fluorescentes ora naquele veludo que prediz o tempo. $\mathrm{O}$ tempo que para ela não passou. Que ficou parado ali, naquela ruptura.

Que ela traz sempre de volta durante o silêncio, ao preenchê-lo com cantigas da sua infância.

Essa ruptura leva, segundo Salman Rushdie (1994), a uma "crise ontológica, porque você é forçado a negociar as condições de sua identidade sob circunstâncias existenciais perpetuamente mutantes".

Sem negar a fissura, o antes e o depois que a imigração abre no indivíduo, Flusser enxerga para além da ruptura; dedica-se a procurar os aspectos positivos que é estar "partido ao meio", como meu pai diz. E encontra.

O exilado pode ser aquele que, sem raízes, entrega-se de todo ao novo; liberta-se do sedentarismo e amplia sua visão de mundo, fora dos limites da sua Heimat (terra natal, em alemão). É ele o ser humano capaz de construir pontes entre culturas - sendo que o futuro, para Flusser, será o do pontificado, da interconectividade. Nesse contexto o imigrante seria quase um übermensch, penso.

Será que é tudo uma questão de perspectiva? Será que em vez de chorar as paredes vazias de tantos quartos alugados eu poderia ter tomado posse dessa sensação de estar à margem e viver em pleno a sua outra face, a liberdade? O fato de ninguém se importar com a nossa existência; de poucos saberem até que existimos; a absoluta consciência de que nossa presença/existência é tão insignificante para a cidade e seus habitantes poderia ser sentida não como um 
universo condenado a ruir, mas como uma carta branca para escolher em que sentido crescer. Que ruas e bairros amar. Que ônibus e trens pegar, para onde ir. O que dizer, o que calar. Um grão de areia, uma concha partida em mil pedacinhos mínimos, cada um guardando em si o som distante do oceano, a tristeza de ser pisado, mas também a hipótese de virar duna, escultura, tempestade, material de construção. Potência.

Basta saber olhar.

Basta?

Liberdade vertiginosa, anota minha colega quando comento alguns detalhes sobre a autobiografia de Flusser. Vários trechos abduziram minha atenção nas últimas semanas; o livro tem me feito pensar e questionar até mesmo a minha vivência emocional. Em dado momento, o autor diz:

O mesmo céu cobre Praga e São Paulo. Ambas as cidades estão inseridas no mesmo espaço impregnado pela mesma guerra. Mas em São Paulo sopra o espírito de um tempo diferente. A notícia da execução do pai espera o navio nas docas do Rio de Janeiro, e em Praga começam as primeiras deportações maciças. Mas em São Paulo se fazem as primeiras preparações para a futura industrialização nascida dos lucros da guerra. A agonia de Praga coincide com a puberdade em São Paulo: choque de dois tempos. Mas não passam de duas formas de percepção, não são realidades. Apenas os que estão inseridos em um dos dois tempos podem vivenciar o choque. Quem flutua por cima dos tempos, quem não tem fundamento, pode conceber o choque aparente como percepção intercambiável. Sobrepondo os tempos, o desenvolvimento de São Paulo aparece como agonia, e os acontecimentos praguenses como sintomas de um futuro radicalmente novo. Este jogo é extremamente divertido, o de trocar categorias, embora jogo no qual a gente não tem parceiro. (FLUSSER, 2007, p. 48)

Estar inserido em dois tempos, ou "ter um pé aqui e o outro do outro lado do oceano", "pra sempre", como meu pai diz. Flutuando entre dois tempos, e por isso não sendo capaz de absorver o choque - ou retorcendo as próprias percepções de realidade para passar por ele. O país onde não conseguimos trabalho condizente com a nossa formação, onde somos tratados como forasteiros ou cidadãos de segunda - quiçá terceira - classe, ainda é lembrado como um oásis, o paraíso de onde fomos expulsos para um destino incerto. Da incerteza pode nascer 
a esperança - por que não? -, mas, presos a um tempo diferente, com metade do coração em outro lugar, não conseguimos sentir as oportunidades de trabalho, de estudo, a posição mais confortável nas relações sociais como sinais de um futuro radicalmente novo. É simplesmente o último destino, o fim da viagem - acabou aqui. Afinal, como estar presente, fixar raízes, se sentir inteiro e pleno se metade sua ficou em outro lugar?

Talvez por isso Deus disse à mulher de Lot para não olhar para trás ao deixarem Sodoma. Porque era preciso deixar a cidade se incendiar, se apagar, morrer e com ela a nossa parte nela para seguir viagem inteiro. Segundo as leis da física não podemos estar em dois lugares ao mesmo tempo, mas podemos aprender a flutuar entre dois tempos. Quem não consegue vira uma estátua de sal, desfazendo-se à primeira brisa. Como se o vento fosse um veículo, transportando rebeldes partículas para o lugar que deixamos.

Flusser foi acolhido por uma comunidade. Passava as noites no terraço discutindo filosofia com os estudantes - enquanto meu avô deveria estar recontando o estoque da quitanda, ou terminando o dia de trabalho na carvoaria.

Por outro lado, mesmo sem ser acolhido por comunidade nenhuma, meu avô fez a América. Chegou com nada, morreu com dois filhos médicos, propriedades, dólares debaixo do colchão. Transformou sua insignificância para o mundo no terreno perfeito para construir, na segurança do anonimato, um mundo próprio. Sólido, consistente com sua noção de sucesso. Talvez, como afirma o téorico e linguista Tzvetan Todorov em O homem desenraizado (2006), quem perde as raízes e é "arrancado de seu lugar, de seu meio, de seu país, sofre em um primeiro momento", porém, pode "tirar proveito da sua experiência".

"Talvez ele se feche em ressentimento, nascido do desprezo ou da hostilidade de seus hospedeiros. Mas, se ele conseguir superá-los, descobre a curiosidade e aprende a tolerância" (TODOROV, 2006, p. 24).

Claro que houve quedas. A história dos meus avós no Brasil (como a de tantos portugueses que imigraram nos anos 1940) não é nenhuma pera doce, como eles mesmo diziam. Mas quem disse que era pera doce o que eles buscavam? $\mathrm{Na}$ terra deles nem as pereiras davam frutos. Eles queriam trabalho. Queriam luta. Vitória para eles só fazia sentido com muito esforço. Eles queriam desafios, possibilidades de criar uma nova vida, deixando para trás aquela amorfa e sem 
horizontes da aldeia. Queriam escrever uma nova narrativa. Amarga, dura, cheia de sacrifícios, que fosse: ao menos essa história tinha vários finais possíveis.

Escrevo, reescrevo e edito, corto mais frases do que aquelas que ponho no papel, mas sigo. Amarga, dura, cheia de sacrifícios: mas com a certeza de que a minha história terá vários finais possíveis. À margem defino meu próprio trajeto e personagem. Estou livre da pressão de me encaixar no molde. Questiono hábitos, comportamentos automáticos ao meu redor; escolho os que acho que podem ser úteis.

É como entrar numa piscina, num lago calmo à noite. Você pode se angustiar por não sentir seu corpo como inteiro, entrar em pânico sem a gravidade para te proteger e prender à terra. Ou você pode fundir pele, poros, água e escuro, sentindo o êxtase de estar disperso, ampliado, sem fronteiras com a noite que cai, flutuando sem amarras. Desmembramento doloroso ou amplitude estática, rasgar de horizontes? Quem decide?

A questão não é decidir se a queda é um salto ornamental ou um mergulho sem retorno. Há quem possa escolher, há quem não possa. Não mandamos no nosso destino. Ou mandamos? Minha avó poderia jogar fora todos aqueles suvenires e visitar a Bahia em vez de Aveiro todos os anos; a questão é quem sobraria dali; se ela não tivesse estrutura para suportar tamanha curvatura, talvez quebrasse. Afinal, como diz Rushdie (1994), "a pessoa deslocada de sua terra natal luta por uma estabilidade narrativa [algo que diga] esta é a minha história - por meio de uma sistêmica nostalgia". Se as memórias formam a coluna vertebral de um indivíduo, elas têm uma função óbvia de sustento - apesar de trazerem consigo a dor.

\section{7.}

Vila verde nem era uma aldeia tão longe de Braga. Moure, sim. 25 ou 40 km? Sem carro, com ônibus em horários esparsos, os meninos se deslocavam de uma aldeia a outra a pé, cortando caminho pelos matagais, mesmo à noite. Era o jeito para visitar namoradas de outro concelho, o primo explicava.

Estamos numa aldeia com precisamente quatro casas. Mentira, supostamente o terreno segue pelo matagal até a ribeira, onde há algumas 
construções abandonadas. Eu e meu noivo visitamos a família dele na terra, em pleno inverno - quando a paisagem é linda mas o terreno e o tempo não estão muito bom para passeios. Dona Laurinda, sua tia-avó, tem 82 anos e ainda não tirou o luto, duas décadas de viuvez. Um filho na Suíça, uma na França, outro no Brasil; e o caçula, que voltou à aldeia depois de anos trabalhando na construção civil na França. Dona Laurinda não cozinha mais; sua nora cuida da casa enquanto ela conta histórias, observa o fogo e vigia. Na mesa o pão é partido de mãos em mãos, o cheiro de queijo de cabra pesa sobre os casacos e a jurupinga desce quente na garganta, despertando as memórias.

Moure é uma vila pequena, poderia ser chamada de aldeia. Em muitas casas só vemos luzes acesas durante o mês de agosto, quando os imigrantes voltam para reencontrar a família e a terra natal. Quase todos os jovens, em uma época ou outra da vida, imigram para França, Suíça ou Alemanha; a padroeira da vila é Santa Helena, segundo eles a protetora dos imigrantes. Ninguém soube me dizer o porquê, e o Google depois também não ajudou.

Estamos sentados na mesa enquanto as histórias começam. A maior parte envolve animais, comida - meu noivo e eu trocamos olhares de "oh, não" sempre que o assunto passa por métodos de cozimento ou de matança e ele dá um jeito de perguntar outra coisa completamente fora de contexto, mudando o assunto.

Mas uma das histórias fez com que eu largasse o copo e o pão com queijo da serra, imóvel como se para escutar melhor.

Era sobre o "euclito", que, quando vivo, metia medo nas crianças, porque era protegido por "sete bacurinhos". O euclito, uma árvore, aquela alta de tronco liso e claro e ramagens verdinhas no verão, sabe? - meu noivo me olhou rindo; já sabia que eu não ia parar quieta na mesa enquanto não tirasse tudo que pudesse daquela história à Grimm.

Quando crianças, D. Laurinda conta, ela e os irmãos evitavam o euclito que, em português do Brasil, com todas as vogais, é simplesmente um eucalipto. Sim, uma árvore, só que de tronco tão largo que duas crianças de mãos dadas não conseguiam abraçar, e cujas raízes, diziam os mais velhos, se estendiam por quilômetros até a ribeira. 
Os eucaliptos puxam muita água dos rios, D. Laurinda diz. Eu só sei que queimam fácil - na área em que minha avó nasceu havia incêndios todos os anos nos hectares com essa árvore.

O filho de D. Laurinda insiste; quer nos levar para ver o famoso mito de Moure - ou o que restou dele. Aceitamos, eu empolgadíssima, ele meio sem entender o porquê de tanta fascinação. Deixamos a cozinha e seus fumos de sopa, lareira e cigarro e entramos na carrinha de dois lugares do primo, que acelera pela neblina. Os faróis altos iluminam a estrada estreita e deserta; o caminho é longo, o inverno engole o final da tarde e já parece madrugada. Não há ninguém nas estradas; a condução ligeiramente alcoolizada do motorista não seria um problema.

No meio do caminho, num ponto de ônibus, vejo uma figura curvada, cercada de pombos. O carro passa lentamente mas não consigo ver seu rosto; acompanho espantada o primo comentar como aquele homem surgiu do nada na aldeia e andava por aí, sem rumo - diziam que era refugiado, da Síria, do Líbano, mas cá para o primo era só um cigano maluco que resolveu viver longe do seu grupo. A assistência social sabe da existência dele? Por que ele não vai para um abrigo, uma Santa casa da misericórdia? - pergunto. Ah, ele lá quer sair da rua? E depois, acha que é justo o estrangeiro roubar o lugar do português pobre num abrigo? Há muitas famílias aqui que precisam de ajuda, perderam-se na droga, endividaram-se... Mulheres cujos maridos se foram e ficaram sozinhas com as crianças, a depender de uma miséria da segurança social... Acha certo que um povo pobre como o nosso pague pelas guerras dos outros?

Fiquei calada, como é óbvio - até porque sou mulher, e, ali, mulher não argumenta, não discute nem questiona o homem. Mas se nem pelas suas próprias guerras vocês pagaram...

O que restava do euclito era apenas um tronco seco, com alguns galhos estendidos para o céu. Impossível imaginar bacurinhos e outros seres enviados pelo demo para desviar os jovens do "caminho do bem" - a heroína farta nos anos 80/90 provavelmente deu conta disso.

Um dos filhos de Dona Laurinda tinha migrado para o Brasil, São Paulo; ninguém tinha alguma vez o visitado, e há uns dez anos ele não aparecia na Vila nem em agosto para as festas anuais, que reúnem imigrantes do mundo inteiro. A 
mulher do primo - Rita, se não me engano - levantou-se da mesa em silêncio e num passo muito lento entrou pelo escuro do corredor que guiava aos quartos. Ao voltar, ela trazia uma foto dele, no Rio de Janeiro, com um Cristo de braços abertos no fundo e um sorriso tão amarelo que só não chamava tanto atenção como o cabelo ruivo, as sardas. Quando éramos crianças dizíamos que ele tinha nascido enferrujado, diz o primo, começamos a chamá-lo Russo e assim ficou lembrado. Dona Laurinda disfarça o olhar triste enquanto parte mais um pão; o primo levanta os ombros como que dizendo que não tinham como encontrá-lo, que não havia nada a fazer.

Dizem que é assim, como estresse pós-traumático. A sensação é parecida, diz o médico. Um murro gelado no estômago e a cortina escura caindo por sobre os olhos, cegando o mundo?, pensei. Minha cunhada se encolhe e desconfia, não há o que fazer - vai passar, eu digo. Esperamos no escuro. Tudo está bem na maior parte do tempo até que quando menos espero vem essa vontade de sumir e essa dor, ela diz. Deixa sangrar até que a dor se canse, digo (até que ela volte naturalmente para seu pouso no peito), penso. E volte a fingir ser aquela saudade que só traz lembranças boas. Aquela dos turistas.

O que disparou isso novamente - o médico pergunta, e eu sei, ela sabe, mas como dizer sem soarmos ridículas? Qualquer queda desperta o coração da anestesia. E sem analgésicos a dor do que nunca mais será, da perda maior, continua aqui. A juventude que nunca mais. A fé. O encaixe perfeito que o "estar em casa", no seu país, com família e posição social herdada sem o menor esforço lhe garantem. Ser você mesmo sem a etiqueta e estereótipo que o teu país determina. O médico estranha - pode ser depressão pós-parto, cogita. Carol abaixa os olhos, seu desânimo passa do seu corpo para o meu como corrente elétrica. Como dizer, depois de ter um filho, depois de conhecer e amar o próprio filho, que tinha saudades de quando não era mãe? Como explicar que o que é para tantas mulheres um renascimento para ela é uma sentença, um rótulo pior do que o de estrangeira, o final da linha? Nunca mais seria a mesma; nunca mais poderia 
começar do zero. Ela se cala, eu me calo e ambas sorrimos afáveis para o médico, tão solícito com as duas brasileiras.

Estou de visita nesse país. Mas é como se voltasse para casa. Flashes do Rio de janeiro pipocam na tela da mente, eu os expulso com insistência - e olha que cheguei a amar aquele país, não como home, mas como abrigo, admito. Amo ou ao menos uma parte de mim o faz.

Eu disse que não seria fácil, sempre disse - mas todos repetiam que ela teria uma vida maravilhosa ao lado do marido diplomata: poderia viajar o mundo; seus filhos seriam bilíngues, trilíngues; conviveriam com a elite de todos os países onde ele fosse trabalhar. O preço a se pagar? Bem.

O preço é diferente para cada um, claro. Meu irmão parecia bem-adaptado e já entusiasmado com a próxima mudança, para um país da América Latina, rezávamos. Minha cunhada passava os dias na cama, de camisola; ou saía e só voltava quando ele já estava deitado; as empregadas cuidavam da casa e da comida, portanto isso não era problema; Sveta, a babá ucraniana, chegava de manhã e ficava com a pequena até o anoitecer. A água dói na minha pele, não, não consigo - ia comprar cigarros na esquina de pijama, como se aquela não fosse uma cidade grande, mas um pequeno condomínio ou uma vila de interior. Onde ela nunca viveu, portanto, nem se poderia culpar o hábito. Meu irmão evitava comentar; cada pergunta que fazia era tirar um tijolo e de repente levar com toda a parede em cima. O cartão de crédito indicava, na fatura, o percurso dela: um bar perto da praia, um café no Cais Sodré, outro perto de Santa Apolónia; um lugar, que ele constatou horrorizado ao visitar, perto do cais, frequentado basicamente por estivadores e pessoal dos barcos. Era o Kopenhagen. Ele me mostrou a fatura, perguntou onde ficava, o que era; eu não sabia para onde desaparecer. No fundo não tinha nada demais: era uma cave sem janelas onde, independente do sol, parecia ser sempre fim de noite. Onde marinheiros cansados e trabalhadoras do sexo locais reuniam-se entre uma jornada e outra, e a música era anacronicamente cafona. Um portal para outra dimensão, na qual copos, garrafas, pernas, dentes amarelados e bocas vermelhas se multiplicavam nas paredes espelhadas. Uma bola de espelhos no teto, casais insólitos - gays idosos, lésbicas, velhos e "dançarinas" do Leste europeu dançando juntinhos. Um lugar mágico: ali ninguém levantava a sobrancelha para ninguém - dava para respirar ar puro, mesmo em meio à fumaça 
condensada dos tempos de fumo livre em espaços noturnos. Meus amigos gays sempre iam, e apesar de não serem público alvo, as "meninas" (nenhuma parecia ter menos de 40) sempre nos faziam sentir bem-vindos.

Quando minha cunhada começou a fazer amigos gays? Ela, que na faculdade achava que toda lésbica estava a fim dela? Quando foi que começou a fumar e a beber coisas que deixavam aquele hálito azedo até de manhã? De onde veio essa rebelião tardia numa mulher de mais de trinta, casada com o primeiro namorado, currículo limpo?

Foi tudo tão rápido; a menina nasceu, ela precisava de espaço, precisava chorar, gritar, depois partir copos. Deixou de amamentar cedo porque o médico insistiu nos remédios; mas sem um monitoramento próximo, ou ela não tomava nada ou tomava tudo só quando queria sentir alguma onda. A babá ucraniana, de repente, virou ama de leite - diz ela que sem puxar nem bombear o seio, só por instinto do corpo mesmo. E a Carol ficou com mais tempo livre. Todos nós estimulamos seus passeios sozinha pela cidade. Todos nós achamos ótimo ela sair com as mulheres do grupo de apoio de depressão pós-parto. Mas os encontros, que a princípio se davam em parques, jardins, começavam cada vez mais tarde e em lugares fora do perímetro sócio-geográfico adequado à mulher de um diplomata. Às três da manhã ele escutava o barulho da chave na porta, os esbarrões nas paredes do corredor, a torneira, a descarga; contava os minutos para esquecer que daqui a pouco ela vinha, deitaria ao seu lado com aquele cheiro de cigarro no corpo, e não havia nada que ele pudesse fazer. Apenas esperar passar. Até que ela voltasse ao normal, à casa, às novelas, às compras online, às selfies na praia. E aquele olhar debaixo dos cabelos, aquele olhar de confiança quando lhe perguntava o que fazer. Agora parecia que ela tinha sua própria agenda, que não incluía ele. E para falar a verdade, nem a menina. Incluía sim um travesseiro para chorar manhã adentro, enquanto Sveta e Carmo empurravam a casa como podiam.

Nessas férias estranhas, meu irmão me pareceu de repente velho, cansado, sem aquele brilho que tinha quando chegou, ou antes do nascimento da filha. $E$ normal, muitas mulheres passam por isso, o médico suavizava; não sei por que, o Rafa calava - esperava que um dia, por mágica, ela voltasse ao normal. Não cobrava, não dava um basta, e eu, ali de férias, não podia fazer muito além de assistir. Nos dois sentidos. 
Carol lava as mãos na pia da cozinha. O antisséptico bucal ao lado do detergente refresca seu hálito. Na bancada da cozinha há três potes para preparar a fórmula da mamadeira: proteína, vitaminas e algo mais específico que deixava o leite com sabor de baunilha - o bebê até engole, mas cinco minutos depois está todo regurgitado.

Ela chegou tarde - do primeiro andar ouvia o barulho da chave na porta de ferro do prédio, esqueceu o código de entrada mais uma vez. Ela gritava com Rafa que não aguentava mais, que queria ir embora; ele tinha tudo e não ajudava em nada, nada, só a botava mais pra baixo por tentar sair e se divertir com amigas. Ele falava baixo, do meu quarto não ouvia; acompanhava o tom da conversa pelas réplicas da Carol, que parecia com tanta raiva de tudo que pensei em ir para o quarto da bebê. Fui transportada para meus dezoito anos, com Teresa e Miguel brigando e o Tiaguinho pedindo abrigo no meu quarto. Só que o menino tinha três anos, sabia andar, falar, pedir ajuda; minha sobrinha ainda era um bebê que, quando chorava, eu mal distinguia se a causa era fome, fralda suja, cólica ou sono.

Aos poucos a voz dela foi baixando e começaram os soluços. Chorou por muito tempo até que eu - e a casa - conseguíssemos voltar a dormir.

O que você faz se destruíram sua casa sua cidade seu país seu homem e você não tem pouso certo além das calçadas, do suporte dos postes, dos balcões, dos ombros masculinos aleatórios dos frequentadores de bares, do vagar sem rumo para confirmar que as próprias pernas permanecem inteiras?

Faz frio nas ruas, faz frio aqui dentro. Encolho-me no casaco, os dias mais curtos sinalizam o Natal, a passagem de ano; estranho a ausência das luzes 
enfeitando as árvores, das estrelas e dos trenós nas praças. Estou em outro hemisfério, digo a mim mesma. No Rio o inverno não é o fim mas o intervalo, um parênteses no calor que se cola na pele.

Mas aqui é outro hemisfério, repito a mim mesma.

Acordei e era sábado, alguns amigos já tinham planos, e eu achava melhor sair antes que meu irmão e a Carol acordassem, para deixá-los sozinhos até porque era muito angustiante a minha sensação de impotência. Nem passear com a bebê eu podia, porque a Carol ficava ansiosa e portanto o Rafael também.

Espero na Rua das Janelas Verdes pelo único ônibus que me levará ao Largo de Camões, em frente ao consulado brasileiro. Quando vivia aqui, domingos e feriados significavam pegar o comboio e seguir para a baixa. Observar as praias nascendo pela janela do trem, num filme de filtro enevoado pelas janelas sujas: Caxias, Cruz Quebrada, Algés, Belém. Descia no Cais Sodré, seguia pela Rua do Alecrim (a subir), e depois, a Rua do Carmo (a descer). Parava no meu café preferido, escondido atrás d'A Brasileira - o café Bénard, onde a especialidade era o croissant. $\mathrm{O}$ cheiro de chocolate invadia o salão, lembro; com a porcelana da xícara escaldando a ponta dos dedos, fumava um cigarro à porta da pastelaria, observava as pessoas. As pessoas e suas sacolas e seus casacos e luvas, as famílias e os filhos, a dor de todas as ruas vazias. Rua da Prata, do Ouro, Rossio, voltar pelo Arco dos Sapateiros. Descer as escadas rolantes da Fnac, folhear livros, novos poemas. Sossegar o coração. Lá fora o inverno, expulsandome das ruas, a noite invadindo as praças e parques. Embalada em sonhos voltava ao comboio e via pela janela o Tejo, depois o mar, depois o Atlântico - uivando de abandono, como diria Al Berto. Mas meu.

Agora não sei bem o que fazer, para onde ir. Parece que perdi minha bússola interna.

Se estivesse no Rio, provavelmente veria o nascer e o por do sol da janela do escritório enquanto adiantava frilas. À noite, quando ele chegasse, podíamos ir jantar, ou tomar uma cerveja num dos inúmeros bares de Botafogo. E assim vencíamos os finais de semana.

Olá - tomei um susto com Sveta se aproximando tão silenciosamente como, enfim, uma babá deve estar habituada a fazer. Cedo espaço no banco e ela senta-se ao meu lado. Dentro de casa, de uniforme, ela já parecia deslocada, uma 
atriz estrangeira escalada numa novela portuguesa, o rosto eslavo de barbie e o corpo de pinup sueca chamando muito atenção. Aqui fora, os olhos claros delineados com um risco azul cintilante, os cabelos escurecidos soltos até o ombro, e o moletom em tons pastéis e neons típico dos imigrantes do leste, ela parecia não só deslocada; parecia cansada. Gasta. As unhas roídas e o olhar ausente gritavam cheap, e de repente tive pena. Éramos duas imigrantes, mas duvido que ela tivesse tido tantos privilégios quanto eu. Normalmente a chegada dos imigrantes de Leste é tortuosa; passam por vários países e molham várias mãos para ultrapassar fronteiras; mulheres procuram um emprego e são traficadas, trancadas em bordéis clandestinos sem direito a passaporte, a vista da janela, à luz do sol.

Entramos por acaso no mesmo ônibus, e por delicadeza sentamos as duas no mesmo banco, embora eu não soubesse muito bem o que conversar com ela.

Ainda não conhecia sua história.

Você não tem saudades de Odessa?, pergunto. Ela diz que sente, claro, mas que a qualidade de vida em Portugal é muito melhor do que a de seu país; aqui seus filhos podem ter uma vida mais saudável, sem a tentação de gangues e drogas e outros perigos, no caso das meninas; e depois, eles já iam à escola pública e tinham amiguinhos portugueses, pais e mães com trabalho, com um futuro, entende? - fiz que sim com a cabeça. Aqui o marido tinha um trabalho digno, na construção civil, com contrato, o que permitia que vivessem no país de forma legal. Ela também, na casa do meu irmão, iria em breve ter um contrato, o que melhoraria muito sua qualidade de vida.

Por que meu irmão ainda não tratou disso?, penso. Não lhe custa nada, tão perto de embaixadores e cônsuls, regularizar essa família toda. Mas lembrei do que o Rafael estava passando com a Carol e abandonei essa crítica rapidamente.

Sveta vai saltar na Baixa também; dali irá pegar o comboio em direção a Cascais e de lá pegará depois um ônibus, que a levará para casa, em Colares. Uma pequena aldeia entre Sintra e o balneário de Cascais, da qual eu nunca ouvira falar. Não há nada ali pra se ver, menina Cristina; há um café e algumas casitas de portugueses, e uns poucos prédios alugados a idosos, angolanos, retornados e povo do Leste, ainda ali em minoria. 
O autocarro chega na parada de Sveta e ela se despede, pedindo para que eu tome conta de Abigail - não deixe o Sr. Rafael esquecer de dar a fórmula, dona Carolina esquece algumas às vezes, está doente, não tem culpa - diz, pisando em ovos. Eu ouço e tento demonstrar que compreendo o que ela quer dizer, a mensagem de fundo; digo que não se preocupe, ficarei de olho até segunda, eu mesma darei fórmula e banho. Sveta sorriu e se despediu com um ar aliviado, e eu não sabia se me sentia feliz por ter confortado a babá ou angustiada pela missão que tinha em minha frente. Nunca tive muito contato com crianças, quanto mais bebês; o medo de cometer um erro grave me perturbava o tempo todo, até que me convenci de que o único erro grave seria a negligência, ou a negação do que estava acontecendo. Eu faria o meu melhor, e, esperava, meu empenho e afeto compensariam o que não soubesse fazer.

Desço na Baixa, perto da Brasileira e sigo em frente na rua do Loreto. A Biblioteca de Camões ainda está ali, intacta, quase como a deixei há dez anos, quando era meu pouso principal além da Biblioteca de Oeiras e da faculdade. Mas a de Camões e a do Palácio das Galveias sempre foram as minhas preferidas.

Encontro uma mesa vazia e sento-me na cadeira de madeira escura, da cor da mesa, das estantes imensas que ocupam as paredes. Estar rodeada de livros é uma forma de encontrar abrigo em qualquer lugar do mundo, ou em qualquer fase má que se esteja vivendo - o que aprendi cedo.

Sveta seguia sozinha, agora a pé. O caminho de sempre: a descida curva afiada por trilhos Praça de Camões, Rua do Alecrim, ladeira abaixo. De lá do início da rua, no alto já via uma pequena porção do azul do rio, que parecia ir se diluindo no concreto conforme avançava. A parte interna da coxa e os quadris queimavam enquanto descia - trabalhar com bebês era viver fazendo mais agachamentos do que numa academia. Por isso, e pelos saltos finos pouco apropriados às pedras portuguesas, ela caminhava devagar; mesmo assim se sentiu 
de repente tonta, cabeça pesada, pernas moles, e só foi o tempo de se agarrar às grades de ferro de uma parte da rua para que a vertigem não a levasse ao chão. Sveta esperava não estar grávida de novo. Os dois filhos não foram bem planejados. Quer dizer, não vieram num bom momento econômico - ela se corrige mentalmente, voltando o rosto para fora das grades, o metal frio despertando sua testa. Sveta abre e fecha os olhos: as grades dão vista para a rua de baixo, aquela que já tinha sido uma red light zone e agora tem um tapete pink para pedestres e bares para jovens ricos em ambos os lados. Aqueles que teriam medo de passar por ali há alguns anos, de dia ou de noite. Com a testa apoiada no metal, os olhos entre as grades, observava: champanherias, casas de drinks, portas e janelas em laranja, roxo, azul elétrico. Tão diferente da pintura descascada dos velhos sobrados que se sustentavam uns aos outros há séculos. Quando a calçada era só meninas de Leste, africanas, brasileiras disputando esquinas com portuguesas. Isso há uns 12, 15 anos, pensou. O que lhe trouxe aquele gosto amargo de novo à boca, o gosto de que já tinha ficado no país tempo demais.

Afastou-se das grades, estava tarde. Desceu a rua, contornando pastelarias e casas de crédito, chegou à estação. No trem ela era só mais uma. Não, nem ali era só mais uma. Os homens ou invadiam seu silêncio com conversas forçadas, ou de longe, olhavam-na de cima a baixo com aquele sorriso zombeteiro. As mulheres observavam suas roupas, cabelo e unhas de cima a baixo, com aquele olhar superior. Sveta odiava ficar de pé; já era alta perto dos portugueses, assim com as mãos agarrando o apoio de teto era um corpo num açougue, para apreciação pública.

Um corpo estranho, estrangeiro.

Um jovem saiu dos bancos de quatro lugares e Sveta finalmente se sentou. Era a sorte do dia: o lugar na janela, com a vista da praia e das gotas da maresia cortando os vidros em seus salpicos. A senhora à sua frente dormia a sono solto; ao seu lado uma angolana (ou moçambicana? Não, já sabia reconhecer) fechava os olhos já pequenos numa Bíblia velha de letras mínimas. A jovem à sua frente mascava chicletes, quase no ritmo da música que escapava dos seus fones de ouvido. Os jovens, esses normalmente eram indiferentes a ela. Nova sorte do dia: sentar ao lado de um jovem. 
Quando chegou a casa o marido já tinha entrado e saído, diziam as latas de cerveja e maços vazios, entre outros vestígios largados na mesa. Em breve os meninos voltariam da escola primária com Ingrida, a vizinha de porta, mãe do Alexandre e da Ana - nomes que poderiam pertencer a qualquer lugar do mundo, ela dizia. Pavló e Olena não tiveram a mesma benesse. Mas Ossip fazia questão de nomes tradicionais - afinal um dia todos voltariam, certo? No início era essa a ideia. Portugal sempre foi uma terra provisória, um hotel onde se abrigariam até a economia do país melhorar. Agora também havia a política - a constante pressão da Rússia, a disputa pela Crimeia, as manifestações silenciadas a gás e granadas pela polícia. Uma colega lhe falara sobre milícias ocupando hospitais, delegacias. Voltar agora não valia a pena. Mas quando?

Pavló, Olena e suas cabecinhas loiras surgiam cozinha adentro, o barulho das mochilas e tênis emborrachados inundando o recinto de alegria. Sveta fez um carinho no rosto dos dois, conferindo o estado das roupas e dos calçados. Nem muito sujos, nada demais. Os meninos correram para dentro, enquanto Sveta picava cenouras e beterrabas para o borsch. Ossip adorava, era barato e sustentava no inverno. Os meninos não se entusiasmavam tanto, mas olha - o que está no prato é para comer - e eles obedeciam. Mal sabiam o quão nutritiva era aquela sopa roxa se comparada às insossas portuguesas, a base sempre a mesma, ou pão ou batata.

Picar legumes era duro no inverno: os dedos ficavam logo gelados e dormentes do ato repetitivo. Os portugueses diziam como você pode ter frio? como se só porque o inverno no seu país era intenso os ucranianos fossem imunes ao ar gelado que cortava os ossos de Portugal. Como se não pudessem sentir porque lá era pior, não era? Sempre porque lá era pior, afinal senão ela não tinha vindo, não é mesmo?

Sveta nem argumentava.

Sorria de leve. Talvez um dia eles soubessem o que é estar longe. Ou o que é ser lembrado diariamente por pessoas aleatórias na rua de que você não é daqui. O que você está fazendo nesse lugar, no meu lugar? Todo nacionalista era dono do seu próprio país. Mas isso numa terra que imigrou tanto não fazia sentido, pensava. Não fazia. 
O barulho das chaves alerta que Ossip chegou; ela largou os legumes cozinhando na panela enquanto lavava as mãos e juntava bacia, gelo, creme. Ossip estava sentado no sofá em frente à tevê, e sorriu daquele jeito triste que tinha desde que se conheceram, numa das vezes em que voltou à Ucrânia. Ele desviou os olhos, levantou a barra da calça dobrando-a até a coxa - hoje os joelhos não estavam tão inchados, mas continuavam gelados e com aquela cor rosa-azulada de má-circulação. Ela pegou a bacia com água quente e deixou cair pedras de cânfora, o cheiro de Vick Vaporub incensava toda a sala enquanto ele afundava os pés no líquido. Sveta massajava seus joelhos com gelo, depois com a pomada que a patroa lhe deu, que era boa para inflamação. Nesta fase da obra, Ossip acertava e nivelava o piso, lixando para que os azulejos ficassem perfeitamente retilíneos ele e os colegas Alexei e Vasyl, também ucranianos, cumpriam as nove horas de joelhos. Era só uma fase da obra, ele dizia à Sveta. Mas por que só os ucranianos eram chamados para esse tipo de trabalho?

Uma fase longa, ela pensava sozinha.

Toda noite Sveta preparava a bacia, o gelo e a massagem, era quase um ritual - pensar em chegar a casa para Ossip era ver os meninos com a cabeças nos cadernos, as mãos geladas de Sveta indo e vindo em seus joelhos, o cheiro de cânfora limpando a sala e os pulmões.

Fui à biblioteca pesquisar sobre $O$ Cartucho, uma coleção de poemas soltos, empacotados literalmente num cartucho (papel de embrulho) de mercearia, que começou a circular em 1976 com poemas de António Franco Alexandre, Hélder Moura Pereira, João Miguel Fernandes Jorge e Joaquim Manuel Magalhães. O objeto - não livro, que Fiama Hasse Paes Brandão chamou de "aquilo", desafiava o leitor com suas folhas "amarrotadas", que lhe conferiam maleabilidade e fluidez. Era como um cartucho de revólver, ou de fogos de artifício; algo explosivo, seja pela dessacralização do livro-objeto seja pela alegria da correspondência coletiva, do caráter lúdico nos dois primeiros anos de uma democracia que ainda engatinhava. Era uma ruptura com o espaço lírico, com os registros emocionais e ideológicos das gerações anteriores; como uma "pirueta 
sobre o real demoníaco", nas palavras de Vasco Graça Moura, em 1976, O Cartucho representava uma "nova orientação da poesia portuguesa, que se anuncia em simultâneo com a Revolução", como explica João Barrento na revista Semear, n. 4 (2000).

Uma poesia feita para ser livre; as folhas amassadas circulavam facilmente e mudavam as regras do jogo, instaurando ideias de multiplicidade, descentramento, fragmentação, abrindo espaço para novas dicções poéticas, voltadas para a realidade urbana, o cotidiano mais comum, em versos que fugiam à dimensão epopeica, desviando-se pela ironia e assim rompendo com formas e discursos sacralizados até então.

Com os novos poetas inventa-se um novo discursivismo e uma nova retórica que levam, ou à encenação fictícia, no poema, das experiências mais pessoais e mais quotidianas (em Nuno Júdice, Diogo Pires Aurélio), ou ainda, com recurso a um largo espectro de linguagem das formas e de formas de linguagem, ao cruzamento dos grandes temas da tradição ocidental (o tempo e a morte, o amor e a arte) com o registo, em parlando, da circunstancialidade mais comezinha e dos interstícios de uma realidade "demoníaca" intensamente vivida. (BARRENTO, 2000)

Só a ambivalência do título já era atraente; era como se poemas fossem granadas à espreita, palavras que poderiam tomar qualquer leitor e explodir subitamente, trazendo à tona a revolta com toda a repressão e censura sublimada durante os longos anos de ditadura. Nem preciso dizer que estou há anos à procura de alguma dessas "folhas amarrotadas" para minha biblioteca.

Numa rápida conversa com a bibliotecária, ela me sugere as Memórias de Eduardo Pitta, poeta e crítico literário retornado, que acompanhou de perto a cena literária portuguesa que surgiu com o fim dos anos de ferro. Folheio rapidamente e depois retorno ao início, para degustar melhor Um rapaz a arder. No livro Pitta fala não só da condição de homossexual português naqueles anos (um homossexual pertencente à elite, sublinho) como traça um panorama afetivo da cena literária do país desde a sua chegada de Lourenço Jorge a Cascais, em 1976 mesmo ano da circulação do Cartucho - até os dias de hoje.

Diante de tanta informação foi difícil focar na pesquisa sobre a "poesia dos cartuchos"; nas memórias havia poucas referências sobre o tema. No futuro, 
espero, alguém se atreva estudar essa obra - e retirar daí algum sumo que possa nos ajudar a entender como artistas procuravam novos suportes e formas de expressão diante da democracia recém-instaurada, após décadas de intensa repressão e vigilância da ditadura. Como, de dentro do concreto rígido nasciam flores, que eram passadas de mãos em mãos como uma mensagem. "É do silêncio de uma época que a Poesia se alimenta", já dizia Eduardo Lourenço (1998, p. 202); os versos da Geração Cartucho atravessavam o vazio, insistindo em brotar e circular independentemente da repressão. Eram respostas, alertas e sinais de fumaça, luta; um exemplo de como a poesia pode alimentar a resistência e a existência em tempos sombrios.

Um trecho de Um rapaz a arder captura imediatamente a minha atenção: quando o autor descreve sua partida e a de seu companheiro Jorge - e o turbulento momento político que a precipitou - de Lourenço Marques, em Moçambique, para Cascais, em Lisboa.

Como previsto, o Jorge (namorado e atual marido de André), partiu no dia 3 de novembro. Pasolini tinha sido brutalmente assassinado na véspera, mas creio que só Lisboa tivesse conhecimento de facto. (...) No dia 8 [eu] estava num avião da TAP a caminho de Lisboa. (...) Já dentro do avião, vi entrar dois soldados da Frelimo que ali mesmo deram ordem de prisão a um casal acusado de pertencer às Testemunhas de Jeová. Por fim, partimos. (...) Às onze da noite, reencontrei-me com o Jorge no aeroporto de Lisboa. Era o primeiro dia do resto da nossa vida. (PITTA, 2013, p. 30).

Quando eu cheguei em Portugal no fim dos anos 90, o país vivia o auge da imigração de brasileiros e imigrantes do Leste Europeu. No final dos anos 1970 e início de 1980, com a queda do império sobre as colônias africanas, a "imigração" predominante era fruto do movimento de retorno de famílias portuguesas estabelecidas na África há anos. Eram os retornados, e, sinceramente, sofriam tanto ou mais preconceito quanto qualquer imigrante de fora. Isso na minha perspectiva, claro.

Os retornados partilhavam comigo e com outros imigrantes a categoria sutil ou não - de cidadãos de segunda classe. Eram cidadãos portugueses, mesmo que nascidos ou vivendo toda uma vida nas ex-colônias, no chamado Sul de Boaventura de Sousa Santos. Viram-se acuados aquando da independência, 
deixando amores, carreiras, casas e bens, sendo estes últimos tomados, tornandose propriedade da nova nação africana.

Sheila Khan explica o conceito de Sul, de Boaventura, como metáfora do esquecimento:

O sul entende-se aqui como a metáfora do esquecimento, do silenciamento e da desvalorização de outras formas de entendimento e de interpretação do espaço sócio-cultural português actual. Não apenas um Sul ex-imperial, mas, também, um Sul que continua marginalizado por uma faltosa consciência histórica sobre as vidas daqueles que testemunharam e viveram a retórica da colonialidade portuguesa, a sua visão imperial de centro civilizador e arauto de progresso e de desenvolvimento. (KHAN, 2015, p. 23)

E continua:

Sobretudo, vidas que cruzaram mares e terras, para desembarcarem na antiga metrópole após a queda do império como consequência directa das guerras coloniais e de libertação dos territórios colonizados, das independências políticas ocorridas nestes mesmos espaços, e do desenlace final perante a longa luta contra um regime ditatorial em busca de um sonho colectivo, que, desse modo, pudesse outorgar a Portugal a vestimenta de um país democrático. (KHAN, 2015, p. 23)

A variedade e diversidade das pessoas do "Sul" que vivem, atualmente, no tecido da pós-colonialidade portuguesa - tecido que Khan define como "ocorrência factual, histórica e cronológica emergente após a queda do império português no Ultramar" (KHAN, 2015, p. 23) - é imensa. Para tentar montar o quebra-cabeças que Portugal se tornou após o desfacelamento do império Ultramar, a pesquisadora busca reinterpretar e repensar os efeitos do colonialismo português no tempo presente, o da pós-colonialidade portuguesa. Para isso, parte de uma projeção polifóônica a partir da qual se reuniram estas diversas gentes do "Sul”, que conta com cidadãos comuns, retornados, assimilados, ${ }^{8}$ investigadores,

8 "Por assimilados, o sistema colonial português entendia todos aqueles [imigrantes das recém ex-colônias que optaram pela nacionalidade portuguesa ] que poderiam, em termos aceitáveis e de acordo com a idéia de progresso e de civilização, ler escrever e comportar-se idoneamente como um português. Ora, esta política assimilacionista redundou em muitos casos na negação e ignorância por parte destes indivíduos dos conhecimentos locais, culturais e históricos sobre o que se poderia chamar, ainda que de uma maneira generalizada, de cultura moçambicana." (KHAN, 
pensadores, etc., refletindo sobre narrativas de vida e identidade no tempo colonial, os vários retratos da pós-colonialidade portuguesa, entre outros temas. ${ }^{9}$

Por mais portugueses que se considerassem devido às raízes genéticas, os retornados eram traídos por sotaques, leituras, memórias geográfico-afetivas quase alienígenas ao português comum, que nunca tinha cruzado fronteiras oceânicas. Na verdade não conheci muitos retornados - ou eram de classes sociais muito altas às quais não tinha acesso, ou viviam na periferia mais periférica na qual, por sorte, não fui inserida. Mas, na faculdade, uma colega vinda de Angola criou uma ligação natural comigo. Nos primeiros dias de aula, nunca poderia imaginar que nascera em Luanda; era portuguesa de pele, feições e sotaque, hábitos, leituras e convenções adotadas. Loira, pálida e de olhos claros, ela tinha o nome exótico de uma bailarina africana, o que era motivo de chacota numa sala de aula onde só haviam Marias, Joanas, Inêses, Ritas e nomes bíblicos permitidos pelo livro de registros nacional. Suas roupas largas e com um quê de infantis, compradas aleatoriamente pela mãe, fechavam o pacote de retornada-esquisita, juntamente com o namorado desajeitado e provinciano, reconhecido de longe pelo casaco de neoprene colorido, cobrindo-o fosse inverno primavera ou alto verão.

N. - preservarei seu nome, facílimo de achar no Google - parecia pairar num tempo paralelo durante a faculdade em Lisboa. Andávamos pelos jardins da Fundação Gulbenkian depois das aulas, dando comida aos patos e relembrando nossas cidades além-mar; o que, no caso dela, parecia ainda mais distante, já que se mudara há anos antes com a mãe para uma aldeia nos arredores da Lourinhã para ter acesso à escola pública de qualidade - e, assim, mais chances de entrar para a faculdade. Visitei uma vez sua casa na aldeia; confortável, cheia de fotos da infância, pai, mãe e ela criança em praias com o fundo do pôr do sol em labaredas,

2015, p. 240) A autora centra seu estudo sobre a comunidade moçambicana que retornou/ imigrou para Portugal após a independência; no entanto, sua reflexão sobre "as gentes do Sul" não se limita a essa comunidade, mas a diversas outras vindas das recém-excolônias.

$9 \quad$ "O encontro entre a realidade humana da experiência ultramarina e a realidade da metrópole sócio-cultural, política e econômica do pós-25 de Abril; A consciência histórica de Portugal mediante as suas Outras-gentes e o modo como Portugal se tem representado a si mesmo, ora como nação que celebra a sua epopeia lusotropicalista, ora como nação europeia." (KHAN, 2015, p. 25). 
marca registrada de Luanda. Conheci sua mãe, uma mulher jovem, que lutara pela independência daquela que considerava sua terra - Angola - e se vira forçada a retornar a Lisboa em meados dos anos 1980, porque, dizia, era insustentável criar uma criança num país ruído pela guerra. O marido ficou, por conta do ótimo emprego como engenheiro; desaconselhava visitas a Luanda, onde, dizia, era impossível andar a pé sem ser interpelado por crianças e idosos mutilados, pela miséria ostensiva rodeando uma pequena elite de negros e brancos cada vez mais milionária, raspando diamantes, petróleo e outros recursos aos quais a população nunca teria o menor acesso. Não lembro do nome da mãe de N.; mas não esqueço a névoa de revolta, culpa e indignação que turvava seus olhos cinzentos. Ela pertencia àquela elite, na época em que Angola era parte do Império português; era considerada pelos negros uma colonialista como qualquer outra, a cor da pele afirmando que usara e abusara daquele povo como os primeiros portugueses, apesar de ter apoiado a revolução, e a independência da nação que considerava como lar.

Depois da crise de 1998, vários colegas nossos de faculdade nem piscaram os olhos e se mudaram para a capital angolana, onde empregos em comunicação e engenharia - e praticamente qualquer coisa - não faltavam.

Durante boa parte do tempo em que a via, a mãe de N. chorava de saudades de Luanda. Assim que a filha se formasse voltaria para lá, com emprego, sem emprego, com marido, sem marido - os anos de distância geográfica ameaçavam a relação, mas ela parecia não se importar muito. Tinha saudades da umidade do cacimbo, que se colava na pele, da vastidão que a engolia no horizonte cor de terra vermelha, da mistura de pessoas nos mercados improvisados nas ruas - do ritmo lento que permitia conhecer os outros, apreciar cada momento. Uma visão romantizada, talvez, mas quem é que não romantiza o lugar que considera como "lar"?

A relação entre N. e sua mãe era um caso à parte; às vezes parecia que era N. quem cuidava da mãe ao vistoriar a caixinha de comprimidos, rechear a geladeira ou sumir com as garrafas de álcool da casa durante suas visitas a Lourinhã no final de semana. A mãe não tinha muitos amigos; já tinha passado muito tempo (na minha cabeça), mas ela era e sempre seria uma retornada, e era difícil para qualquer um que voltasse ser aceito novamente. Era complicado para 
mim compreender a lógica louca por trás desse preconceito na época - eu era jovem e acreditava delirantemente que deveria haver alguma coerência na resistência ao Outro, mesmo que esta tivesse base no medo. Mas resistência por orgulhos, intrigas políticas e econômicas, guerras e lados escolhidos, isso não parecia suficiente para tornar uma parte da população em sudras portugueses. Enfim, eu era jovem e ingênua.

A culpada de a mãe ser assim é esta terra. Sempre houve duas terras para a mãe, esta que a adoeceu e a metrópole onde tudo é diferente e onde a mãe também era diferente. O pai nunca fala da metrópole, a mãe tem duas terras mas o pai não. Um homem pertence ao sítio que lhe dá de comer a não ser que tenha um coração ingrato, era assim que o pai respondia quando lhe perguntavam se tinha saudades da metrópole. Um homem tem que seguir o trabalho como o carro segue os bois. E ter um coração agradecido. (CARDOSO, 2013, p. 11)

Acho que só ao ler Dulce Maria Cardoso, anos mais tarde, pude distinguir algumas das emoções dos olhos da mãe de N., e ter dimensão do tamanho do buraco histórico em que os retornados costumavam ficar. Há um trecho, entre vários de $O$ retorno, que descreve o abandono em que os portugueses de Angola ficaram, seja lá, seja ao voltar:

Já se foram todos embora. Os meus amigos, os vizinhos, os professores, os donos das lojas, o mecânico, o barbeiro, o padre, todos. Nós também já não devíamos estar cá. A minha irmã acusa o pai de não se importar com o que nos possa acontecer e por vontade da mãe teríamos ido embora há muito tempo, ainda antes do Sr. Manuel. Não acredito que o pai não importe conosco apesar de não perceber porque ainda não nos fomos embora quando pode acontecer-nos uma coisa má a qualquer momento. Os soldados portugueses já quase não passam por aqui e os poucos que vemos têm os cabelos compridos e as fardas desleixadas, os botões das camisas desapertados e os atacadores das botas por atar. Derrapam os jipes nas curvas e bebem Cucas como se estivessem de férias. Para o pai os soldados portugueses são uns traidores reles mas para o tio Zé são heróis antifascistas e anticolonialistas. (CARDOSO, 2013, p. 11)

Eu não tinha tantas saudades assim do Brasil quanto tinha de ser considerada "normal", ou uma cidadã plena, com acesso total a bens culturais e a 
um nível social mais alto. Obviamente, como elas, não me identificava com o lugar de imigrante de uma ex-colônia, mas simplesmente como imigrante, estrangeira. O papel a que a sociedade nos empurrava era tão alheio, tão diferente de como nos sentíamos, que era quase como se nosso eu fosse, no fundo, invisível. Ninguém queria ver. Abriram um espacinho para que entrássemos e participássemos de alguma forma da sociedade; papel marginal, de segunda, cheio de proibições e limitações - mas era o que havia e já deveríamos estar muito contentes com a generosidade da nação.

Quero que as pátrias todas vão passear

Até ao Jardim Decente E voltem depois não como pátrias Mas como gente.

Alberto de Lacerda ${ }^{10}$

Retomo a leitura de Sheila Khan, que repensa a expressão proposta pelo sociólogo Boaventura de Sousa Santos - a de sociologia das ausências para refletir sobre o que designou como sociologia pós-colonial das ausências. O objetivo desta sociologia pós-colonial seria justamente transformar os silêncios e as ausências socialmente produzidas em peças humanas, dando-lhes visibilidade, reconhecimento e validade. Com um olhar mais atento e aberto às contribuições sociais, humanas e ontológicas deste "Sul” pós-colonial, seria possível uma interpretação mais transparente, concreta e interventiva sobre o que é hoje o póscolonialismo de expressão portuguesa.

Difícil reprimir o desejo de voltar, no caso delas, ou de viver numa bolha de amizades confortáveis, como eu. Difícil lidar com a realidade.

10 Disponível em: <https://www.publico.pt/temas/jornal/alberto-de-lacerda-opoeta-expatriado-227671>. Acesso em: março de 2017. 
Ao longo dos anos, perdi contato com N. A última notícia que tive sua é que casou e foi viver na ilha da Madeira. Pelo menos um lugar quente, tropical, sem o tapa no rosto diário da miséria e desigualdade de Luanda.

Ou do Rio.

Um senhor parece me esperar na saída da biblioteca. Só parece; sentado nas escadas, provavelmente se abrigava do início de inverno. Era um sem-abrigo, forma politicamente correta de se dizer mendigo aqui - a sacola de lixo carregando pertences, o terno surrado e as calças num número grande demais para o corpo franzino o denunciavam. Ainda de costas para ele, vejo um pombo que se aproxima sem medo, enquanto ele joga algum grão qualquer no chão. De repente todos os pombos da cidade pareceram aterrissar naquelas escadas, e eu fico ali em cima paralisada, esperando a nuvem passar para o caminho se abrir para mim. Os cabelos grisalhos na pele curtida de sol e poeira, iguais aos de Otto. Como será que ele estaria, com a política de higienização urbana (que na verdade é humana, varrendo moradores de rua como se fossem lixo) pelo Rio? Espero que não tenha sido enviado à força para um abrigo. Da última vez foi triste; passou madrugadas andando pelo quarteirão, perdera seu posto habitual e não tinha onde dormir em segurança.

Na biblioteca, além do estudo sobre a poesia dos cartuchos, um livro sobre a vida de Rothko (1903-1970) me fisgou. Estava ali, pousado na mesa enorme de carvalho escuro, provavelmente esquecido por algum estudante de Belas Artes ou História. A capa, uma reprodução de White Center (Yellow, Pink and Lavender on Rose), obra de 1950, descansava meu cérebro e atraía a atenção, depois de tanta leitura, escrita, memórias. Folheio as páginas do livro de arte, feito essencialmente de figuras, só para descobrir, em poucos minutos, que estava à beira de mergulhar em mais uma biografia de um artista imigrante, vivendo no 
exílio. Afinal, Mark Rothko tinha nascido em Dvinsk, atual Letônia, imigrando para os EUA em 1913, com 11 anos devido a perseguição aos judeus.

Acabei lembrando de um link que há séculos uma colega me enviou, uma palestra da professora Annie Cohen-Solal sobre Rothko, arte e desenraizamento. De alguma forma, na bagagem de leituras do mestrado, aquele texto precioso tinha ficado para trás, esquecido como se nunca houvesse sido recomendado talvez por ser em francês, que não domino, eu tenha abandonado a leitura nas primeiras linhas e empurrado o tema para o fundo das memórias. Ao chegar a casa de Rafa e Carol, e na ausência dos três, assisto o vídeo com mais avidez do que devoro a açorda.

Annie Cohen-Solal parece concordar com Flusser e com tantos, que descubro a cada dia, no potencial que o desenraizamento, deslocamento e imigração podem despertar no indivíduo:

Diante da "crise migrante" que iria testar as defesas de segurança da Europa, a posição dos artistas é particularmente edificante. Desde Vasari, sabemos que a mudança geográfica é capital na profissão artística, local intercultural por excelência. De fato, a partir dos séculos XX e XXI, como resultado de guerras e regimes totalitários, os contatos entre migrantes e as sociedades mudaram a cena artística incontornavelmente, prenunciando as nossas formas culturais cosmopolitas atuais. (COHEN-SOLAL, 2015).

Tendo como tema principal de sua obra o artista judeu-russo, que emigrou para os EUA ainda menino, Cohen-Solal observa como a vivência do desenraizamento provocou experiências violentas nas relações do artista com as instituições e em suas interações com certos atores; e como, mesmo no seio de uma sociedade capitalista triunfante de ambiente hostil, produziu um trabalho pioneiro, vibrante ainda hoje.

A sustentabilidade da mensagem de Rothko novamente sublinha a urgência de considerar cuidadosamente a função do artista emigrante ou exilado. Como foi que artistas como Pablo Picasso, Sheerin Neshat, Anish Kapoor, Huang Yong Ping, Christo Javacheff ou Abdessemed, confrontados com os desafios da viagem geográfica, negociaram seu próprio desenraizamento para configurar léxicos inéditos, desenhar política, ética e antropológica, fizeram explodir visões, identidade e fronteiras? Neste sentido, a 
linha de frente, escapando às determinações impostas pelo poder, não propõe nenhuma nova dinâmica social e cívica, bem como mudanças estéticas? (COHEN-SOLAL, 2015.)

Naquela manhã em Lisboa acordei tarde como sempre, depois de mais uma noite de insônia - os olhos vagando pelas roupas estendidas nos varais vizinhos - exausta fui me arrastando da cama pelo corredor até a sala, e parei ali no batente surpresa com a visão das duas. Sveta e Abigail. Babá e criança entretidas com tinta guache e telas onde as cores explodiam, gritando mudas em traços, pingos, manchas na tela e nos dedos sujos de tinta. Eu assistia maravilhada - como nunca reparei? - àquele big-bang microscópico, como um quintal seco em que um dia botões se abrem em flores na madrugada, lagartas rompem casulos, abrindo asas de borboleta com uma leveza insustentável para quem só conhecia seu estado rastejante. Sveta era tão sóbria e introvertida nas interações com nós, adultos, que nunca parei e notei como seu rosto se iluminava ao lado da minha sobrinha, com um amor e um desejo de ver o outro crescer tão raros. Tão raros como só os que não pertencem à mesma família podem ter uns com os outros, refletiria mais tarde. Mas ali, na hora, parecia incrível. A bebê que passava os dias e noites rodando a casa imensa, esbarrando nos móveis e colecionando acidentes domésticos era pura alegria no meio da tinta, dos dedos sujos nos cabelos cor de milho de Sveta.

Quando percebeu minha presença, a babá contraiu o sorriso e retomou a postura distante habitual, embora os braços segurassem a bebê contra o peito, protegendo-a - do quê, do meu olhar invasivo? Provável. Eu, a rainha do traquejo social - para não dizer o contrário -, me vi obrigada a fazer conversa para tapar o rombo enorme que havia aberto na harmonia do momento. Não lembro como a conversa começou, foi de repente. Sveta ia contando como os filhos adoravam a escola portuguesa, como Ossip se orgulhava das crianças, como Abigail tinha sorte de crescer viajando o mundo e aprendendo línguas - para as crianças era muito mais fácil imigrar, dizia. Seus filhos corrigiam o sotaque dos pais o tempo todo, odiavam a visita de parentes e fugiam a qualquer menção ao Leste europeu, era como se quisessem ser anônimos portugueses, sem orgulho nenhum da própria terra, comentava. Mas e se para eles a terra for essa daqui? - perguntei, e ela 
Pois, não é absurdo? Até do próprio nome reclamam, a filha outro dia pediu para trocaram o nome para Cátia, que servia aqui ou lá, isso não é loucura, querer parecer o que não se é? Abigail não vai passar por isso, acrescentou, e eu comentei que o nome dela era motivo de piada entre portugueses e brasileiros, e de que serve um nome compreensível para a comunidade internacional, mas completamente diferente do teu sobrenome e da tua história, e ela concordou. Fiz um café, perguntei como ela achava que Carol estava no momento. Dona Carolina está um pouco doente, mas já melhora respondeu, desviando os olhos para o tapete. Terreno movediço.

E você, pensa em voltar? Seu marido pensa? "Não, agora não. Nem Ossip pode deixar o emprego, nem as crianças podem deixar a escola." Mas e se houvesse emprego lá - "oh não, não agora. É muito duro isso de começar tudo de novo", ela disse. Disso eu sei bem, comentei. Pelo menos não tenho filhos, posso ir e vir. Isso de ter que mudar de país de três em três anos para mim é a definição de inferno. Mas deve ser tão mais fácil quando se tem dinheiro.

Sveta arrumou a franja para trás da orelha e desviou o rosto, pousando a caneca de café na pia. Um silêncio estranho se abriu novamente, e só agora percebo - talvez tão desconfortável quanto falar dos patrões fosse ter uma conversa forçada com a irmã do patrão como se fosse uma colega, quando, no perímetro daquela casa, ao menos, havia um desnível social imenso entre nós duas. Nós podíamos ser uma tão imigrante quanto a outra do lado de fora, mas não naquela casa, onde ela era empregada e eu, visita.

Sveta me lembrou o tempo em que eu era assistente de produção de uma pseudocineasta angolana, casada com um velho francês que financiava todos os seus projetos, por piores que fossem. Foi um dos meus primeiros empregos, ainda na faculdade - só aguentei três meses, os projetos eram muito fracos, o marido da minha chefe passava os dias no escritório bebendo uísque e se insinuando para as empregadas, e bem, o salário não compensava o constrangimento da situação toda. Enfim, o ponto era que eu, brasileira, estava a viver há muito mais tempo em Lisboa e reconhecia nela todos os traços e falas de um imigrante recém-chegado que irritava e afastava os portugueses, detalhes que passei anos corrigindo em mim mesma para ser "aceita". Um lado meu achava revoltante que uma recémchegada tivesse acesso a uma aceitação social automática só por ser casada com 
um europeu e ter dinheiro. Ao mesmo tempo, isso me unia às minhas colegas portuguesas, que calavam ainda mais o orgulho de trabalharem para uma angolana que só usava Dolce \& Gabbana e mal pagava os estagiários. Ou talvez só por ser angolana e rica e se considerar francesa. Ou talvez por só ser angolana. Perverso, claro, horrível. Tão horrível, percebia agora, ao pensar que Sveta poderia sentir desconforto ou revolta parecidos, embora eu não tivesse nada a ver com a minha ex-chefe. Ao menos eu pensava. Talvez para ela eu tivesse. Talvez para ela eu fosse uma imigrante tão fake quanto meu irmão, Carol, minha ex-chefe, e todos os que não precisam deixar o próprio país para sobreviver, que imigraram por escolha. Talvez houvesse um abismo entre o exilado, o imigrante por questões econômicos e quem tinha liberdade de ir e vir, bastava querer. Talvez pensar o exílio como uma questão subjetiva seja uma ofensa para quem se vê forçado a deixar o próprio país por razões políticas e econômicas. O desconforto de Sveta era pior que a distância dos portugueses. Era como se até o espaço de imigrante me fosse negado.

Agora entendia melhor a Carol.

(...) brincar com o suicídio proporciona a liberdade diabólica do jogo entre os tempos e com os tempos.

O jogo é solitário e não admite parceiro. Todo contato com os demais imigrantes tinha que ser minimizado. Estes se jogavam, precipitadamente, nos negócios fáceis, porque esqueciam da guerra e consideravam o Brasil uma etapa provisória no caminho de volta. Mas para a gente a guerra não era realidade, nem o Brasil etapa provisória, mas mais outra irrealidade. Eis a razão por que os demais imigrantes causavam nojo: não aceitavam nem a realidade da total irrealidade. Lucravam da guerra que choravam e tomavam por realidade, e despojavam o Brasil, pensando que estavam contribuindo para o seu "progresso", embora não o tenham aceitado como realidade. Tal distanciamento dos imigrantes possibilitaria, mais tarde, abertura em direção ao Brasil, e, mais tarde ainda, a penosa decisão de cortar as novas raízes. Problemas que os demais imigrantes não terão, nem um, nem o outro. Mas tal distanciamento criava, de imediato, o seguinte: na medida em que a gente se comportava como os demais imigrantes (e como a burguesia brasileira), a gente se desprezava a si própria, e na medida em que a gente se comportava de forma diferente, a gente 
se afastava tanto dos imigrantes quanto da burguesia brasileira. $\mathrm{E}$ isto reforçava o pensamento de matar-se. (FLUSSER, 2007, p. 50)

A criança já dormia e eu tentava encerrar a conversa num clima mais ameno; comentei com Sveta que gostaria de saber pintar, e ela confessou que depois do trabalho frequentava um curso de pintura, planejando entrar no curso de Belas Artes da Universidade de Lisboa. Depois do curso poderia dar aulas em escolas e creches, ter uma estabilidade econômica bem maior do que a de uma babá, emendou. Depois de oito horas de trabalho, três de condução, de onde tirava energias para um curso noturno? Ora, ela era imigrante, e Lisboa era a América dela. Seus filhos e netos seriam a prova disso. Como eu, Rafa e Abigail somos.

Essa menina não tem raízes - a médica disse. Fixei meu olhar no mosaico do chão do hospital particular enquanto a psicóloga-pedagoga articulava em voz alta o que todos nós pensávamos em particular. Claro que Carol levou a mal, claro que era um comentário invasivo e que de nada ajudava a aliviar a ansiedade da criança e da mãe. Claro que era um comentário óbvio, que ninguém a não ser um estranho se atreveria a fazer. Com um universo reduzido ao pai e mãe (quase sempre ausentes) e babá, sem avós, tios, primos por perto, sem saber falar e forçar interações, a solidão e ansiedade se comunicavam pelo seu andar incansável pelos cantos da casa, esbarrando em quinas e móveis, caindo aqui e ali, como apontavam os hematomas, a insônia. Tenho trinta anos e não conseguia dormir pensando nela. Se fosse um bebê, como poderia fechar os olhos sem ter medo de que o meu pequeno mundo se apagasse ao cair das pálpebras? 
“Abigail, Belle Of Kilronan”, Magnetic Fields

Eu não podia fazer nada pela minha sobrinha, além de perder o sono. Se tudo desse certo, a mãe iria melhorar com o tratamento e lhe daria mais atenção, o que diminuiria a ansiedade das duas. Talvez no próximo país eles se sentissem melhor, ela já estaria numa creche, com outras crianças, a mãe teria mais tempo, liberdade; talvez o casal fizesse novos amigos e não falassem do Rio de Janeiro todos os dias. Talvez se sentissem em casa. Pelo menos durante três anos. O mínimo até que a pequena aprendesse a se defender da solidão.

Esperemos que ela não partilhe dos meus genes.

Uma das personagens de Murakami no 1Q84, quando se fecha num apartamento fugindo de seus perseguidores, diz que se sente recolhida como "um gatinho com a pata machucada". Quando sentem dor, os animais normalmente vão para um canto e ficam quietos-quem tem cachorro sabe o olhar de tristeza e pânico que eles nos devolvem quando tentamos tirá-los dali, levar ao veterinário, dar algum remédio. Eles só querem ficar no canto deles, serem deixados em paz, até a dor passar.

Voltei de viagem um pouco perdida, o coração preso sem ter como ajudar irmão, cunhada, sobrinha - quebrado por mais uma vez ter que dizer adeus à cidade que deixei e que nunca me deixou. Um mês de férias é o suficiente para tirar qualquer um de órbita. Que dirá um mês "perdido", como diziam meus amigos do Rio, semanas reforçando a tatuagem de cada nome de rua, bairro, igreja, miradouro, banco de praça. Enchendo daquele azul pleno único olhos peito 
e coração, revendo o tom róseo com que a luz tinge as pedras e paredes alvas de Lisboa. Olhando a lua imensa reinando de um terraço de um prédio para investidores estrangeiros, escavado no coração da cidade gentrificada. Recolhendo caracóis, folhas e lama durante o dia, até a época das chuvas passar, sem pensar no porquê-afinal, no verão eu já não estaria ali mesmo. Quer dizer, eu achava. Porque, pensava, a vida dá tantas voltas que não é tão improvável que termine meus dias vendendo pão de forno artesanal nas feiras itinerantes das terras do interior profundo do país. Como minha avó nas férias, acompanhando os irmãos. Como meus tios-avôs e primos ainda fazem. Difícil? Depois de tanta coisa, não duvidava de nada.

Nem duvido.

A viagem foi mais do que sempre tinha sido: dessa vez parecia que a distância era apenas um botão de pause, que eu podia voltar do mesmo lugar, andar casas atrás ou para frente de acordo com o afeto mútuo.

$\mathrm{O}$ ano começou em Vila Verde: quando eu e ele pegamos um trem rumo a um interior desconhecido, parando em herdades vazias para colher limões sicilianos, ouvindo histórias de terror da boca de primos e tios somente para nunca mais esquecer, honrar a narrativa ao redor. Nós dois perdidos numa aldeia fora do mapa, em Trás os Montes.

Correr a estrada com ele, levá-lo ao início de tudo - a aldeia natal do avôe ver a narrativa nascendo a cada pedacinho de terra que seus olhos registravam e guardavam como um tesouro-ajudando-o o guardar histórias e memórias como o tesouro que são.

Estava lindo, perfeito, até voltarmos. Sábado, pleno carnaval-e foi dada a largada para 2016. Ou melhor - só aí começou. O mês anterior virou uma neblina, um sonho etéreo que ficou lá atrás depois da queda. Uma queda espetacular de uma escada em caracol, seguida pelo ataque de um gato alucinado que, no seu estado normal, parece um bichinho de pelúcia; gritos, berros e de novo o cheiro de ferrugem do sangue nas paredes, nas pernas, braços, no cabelo, no segundo corte na cabeça em dois anos. Por sorte não foi do mesmo lado da cicatriz da última queda. Chorei dias e dias; não fazia sentido, como naturalmente acidentes não fazem; durante semanas sentia ainda a cabeça batendo no degrau, os vidros dos quadros caindo, o gato voando em cima de mim como um vampiro, 
num cenário de sangue, gritos e humor negro como o de qualquer filme de terror lado B. Acho que o Zé do Caixão podia fazer um bom uso do script.

O ano só começa depois do Carnaval; pelo menos foi quando 2016 realmente começou. Os exames de rotina dele foram uma puxada de tapete: nódulo, cirurgia, médicos ambivalentes em relação ao que fazer e a decisão — um segundo round de quimio. Um orgulho enorme da força deles, uma vergonha imensa de não estar à altura. Aliás, a certeza de não estar nem de perto à altura. A vontade de sumir novamente. A certeza de que sumir seria de um egoísmo e crueldade extremos. A solução de compromisso, como dizem os psicanalistas- o sorriso estampado no rosto, o coração amordaçado para não criar mais problemas com seus ais.

Deu certo.

Passamos por tudo; eu, a rainha do drama, não fiz escândalo. Fiquei quieta.

Tão quieta. Como numa loja de porcelana, onde qualquer movimento poderia quebrar o cenário, o encanto, o precário equilíbrio do pequeno mundo ao redor. Mundo esse cada vez menor. Porque foi essa a saída-tornar o mundo menor. Assim corria menos risco de estragar o meu entorno. As poucas pessoas que continuavam ao meu lado tinham fardos maiores, e caramba, o mínimo que eu podia fazer era ficar calada e não preocupar ninguém. Certo?

Tudo não passava de sombra, Era-se holograma entre holograma de pessoas, cidades e países. A história do mundo se desenrolava como tela de televisão, e provocava o mesmo interesse sensacionalista. Pois isto é Londres? Por que não? Londres ou Johanesburgo, pouco importa. Nomes vazios. Viver em Londres, holograma entre hologramas? Perfeitamente viável. Apenas duas condições devem ser preenchidas, ambas fáceis. A primeira: ganhar dinheiro suficiente para nutrir o corpo. Fácil, porque doravante não importa o tipo de trabalho. A segunda: conservar o papel de observador distanciado. Fácil, porque isto é a situação da gente [os sem fundamento]. (FLUSSER, 2007, p. 41)

As aulas começaram, e eu só queria ficar parada sem me mexer ou falar, até a dor passar. Ser uma observadora distanciada. Peguei o ônibus para a faculdade nas primeiras semanas só para parar no meio do caminho e voltar de táxi correndo, o coração na boca e o pânico de abrir a porta da sala e enfrentar 20- 
ou 30? - pares de olhos em cima de mim. Quanto mais não ia, mais duro era tentar aparecer. Quanto mais não escrevia, mais impossível era escrever. Mas como seria possível escrever, falar, ouvir, se minha principal tarefa quando acordada era segurar, não deixar vazar o que o coração queria gritar?

Era como se tivesse perdido as chaves de casa e não pudesse entrar nem sair; ficava parada no corredor esperando alguém chegar, a porta magicamente se abrir com a manhã, algum vizinho simpático se oferecer para arrombá-la. Naquele espaço estreito era impossível calar as vozes internas e ouvir o mundo, se deixar novamente encantar, interessar, fisgar por ele.

O ano começava, nós voltávamos para casa.

São pequenas - quase todas as que colhi naquela tarde têm um ar alaranjado como se ao serem lixadas pelas águas e areia ganhassem ferrugem. Redondas, algumas do tamanho exato de uma unha do polegar - do meu polegar, pequeno, mais precisamente do tamanho de uma pétala de flor de coentro ou alfazema, se é que as dimensões de uma espécie de flor possam alguma vez serem precisas. Em quase todas o furo, cicatriz mínima deixada pelas correntes como, trinta anos depois, a marca de vacina no braço.

Penso em brincos e colares. Penso na água deslizando perfeita naquele furo cilíndrico, a água gelada do mediterrâneo no inverno, a sopa quente em que vira o mar quando é verão. Estamos em janeiro; o ar da maresia nos faz bem, entra gelado nas narinas enchendo o pulmão de azul. Ele observa o mar do areal, me afasto; não resisto e sigo sozinha pela areia, sapatos, gorro, luvas e sobretudo em direção ao azul - quero a espuma branca, o momento exato em que as ondas quebram e se derramam na costa, ser com o mar no momento e movimento. Já sem luvas vou e venho sorrindo com a correnteza, ondas pequenas e rasteiras como as de um rio, apanhando meus pés em botas geladas. Quando menos espero um cachorro surgindo do nada atira as patas sobre meus joelhos, quase me derruba e some num segundo seguindo na obsessão de cavar buracos na areia. Rio confusa com o embate do encontro, a dona se desculpa, à 
toa: quando está na praia ele passa o tempo todo nisso, explica, extraordinariamente ao meu lado e de repente já não.

\section{Cachorros também catam conchas}

procuram memórias no fundo da areia?

E eu lembro.

Era noite. Eu com medo e com frio, ele sem paciência para tanta imobilidade. Nós sozinhos na cidade escura de metropolitanos vazios. Cada um de nós a cada minuto mais cada um, trancados no próprio silêncio.

$\mathrm{E}$, de repente, o impasse. $\mathrm{E}$ de repente as águas que não paravam de nascer nos olhos. Gotas salgadas pesando na face. Vamos para a praia, vamos ver o seu mar, insisto. Ele me segue, a contragosto.

Caminho para a praia, inteira na tarefa de salvar-nos da noite, reunir sombra e silhueta, mãos e olhos novamente; respiro fundo, chamo pelos deuses de outrora e traço com a varinha mágica dos dedos nossos nomes na areia, e me certifico de que estamos muito longe das ondas e de que a inscrição será eterna ao menos até virarmos de costas e nos afastarmos

\section{[como em qualquer feitiço:]}

em troca ofereço palavras até então minhas ao fundo do mar e sei que as perco; águas vivam dançam num raio de luz no azul negro colhendo a oferta; só quero vê-lo sorrir, só quero acalmar seu peito. E disso as ondas entendem como ninguém.

Ele cede um meio riso - eu sigo no escuro para terminar o serviço nas águas noturnas, murmurando a prece protegida pelo breu da noite, onde só uma leve crosta branca distingue de vez em quando o céu do mar. Só queria sumir - a voz dele ecoa no búzio do meu peito que se apequena. Faço o que sei fazer: mergulho pés, mãos e rosto na água escura e espero a pérola surgir. São meus olhos que a fabricam?

Toma, olha aqui o teu amuleto, digo, brincando, enquanto coloco a pedra nas suas mãos quentes, que me retêm. Como a dos nossos pais, tios, avós. Pedras, ondas, adeus. E o nosso encontro. 
Sair de Lisboa era difícil. Chegar ao Rio era mais ainda. Sempre foi, mas não dessa vez. Porque dessa vez havia ele, no aeroporto à minha espera, com a agora nossa cachorra no colo. A mesma que, dias depois, veio trazendo na coleira a cestinha com a caixinha de alianças. Como é diferente voltar quando se tem alguém à nossa espera. Talvez pessoas possam ser países, continentes, universos nos quais construímos nosso abrigo. Nossa casa. Voltar à terra natal era um sonho, voltar para casa melhor ainda. Nossa casa está no encontro dos olhos de quem amamos, em um abraço.

Quando comento que ela é meu talismã, as pessoas acham que é exagero. Não sei é como as pessoas sobrevivem nesse mundo sem contar com o amor incondicional de um cachorro. Minha pequena há dez anos era meu tudo, ela, meus livros e meus cadernos indo e vindo de Lisboa para o Rio em várias viagens, visitas, tentativas de ficar até assentarmos - pelo menos por uns anos. Chegar e encontrá-la, seus olhinhos de azeitona piscando, as orelhinhas viradas para baixo, entregue, é indescritível. O corpinho mole, flexível, encolhendo-se para caber no meu abraço. Um filhote que resgatei de um abrigo no interior de Portugal - por coincidência, numa aldeia vizinha à dos meus avós. Imigrante como todos nós.

Passeando com minha cachorra pelo quarteirão, procuro por Otto. Mas ele não está debaixo da marquise habitual, o prédio antigo da prefeitura que lhe servia todas as noites de abrigo. Nem encostado ao muro da escola. Nem na praça, esperando a van das marmitas. Nem na rua de trás da praça, onde ele às vezes se escondia das intervenções dos assistentes sociais, que ficam coagindo pessoas em situação de rua a entraram numa Kombi a caminho de um abrigo qualquer em Campo Grande - longe de todas as referências que um idoso sozinho, há anos na rua, custou a construir e manter. Era difícil vencer minha timidez, mas a preocupação falou mais alto; acabei sondando com porteiros da rua se o tinham 
visto nos últimos dias, semanas. Ninguém sabia de nada.

Talvez só eu reparasse no Otto. Se meu noivo não o tivesse visto tantas vezes comigo, pensaria que poderia ser um subproduto do meu inconsciente, que espelhou um personagem em diversos moradores de rua anônimos. Mas não, eu conhecia Otto. Sabia dos seus hábitos, suas sutis estratégias de sobrevivência; conhecia suas roupas, seus horários, os locais onde poderia estar dormindo. Não, ele não era uma alucinação.

Não encontrei Otto, mas, ao virar da esquina, sorri por dentro ao avistar a figura trôpega de Russo, sentado no degrau do seu pé-sujo habitual, um cigarro e um copo americano de café filtrado, que sorvia lentamente. Havia um grupo no bar, todos de pé esbarrando de quando em quando na figura abancada no degrau, ainda mais disforme que antes - o corpo inchado de álcool e remédios (imagino), o rosto avermelhado, os cabelos arruivados penteados para trás. A bermuda de ginástica com um tênis branco, como num uniforme de educação física escolar. Concentrado na tarefa de fumar, não reparou que eu chegava; os olhos continuaram examinando o asfalto cinzento da calçada. Perto do botequim, reconheci o BMW da sua irmã - era fácil, afinal era o único carro da marca que ousava estacionar na rua escura em frente ao botequim. Talvez Russo ficasse incumbido de tomar conta do carro para irmã; talvez ele vivesse com os pais, num prédio sem garagem, e ela, de visita, não tinha opção senão estacionar ali.

Aproximei-me dele com tantas perguntas na cabeça mas todas sumiram quando seu rosto levantou-se para me encarar, os olhos fixos em mim e os dedos coçando o queixo num tique nervoso. Sua pele estava vermelha, num exantema ou urticária provavelmente derivado dos próprios remédios. Ele demorou mas conseguiu forçar um sorriso meio torto; minha cachorra avançou para seu colo, como sempre afável com o amigo da rua, ela que late para Shi Tsus indefesos e aterroriza as crianças do vizinho. Afagou a cabeça da pequena, que se jogava em suas pernas dobradas, e eu aproveitei para me sentar ao seu lado, no degrau do pésujo.

Não, não sumi, Russo; fui passar férias na casa do meu irmão, em Lisboa. E olha, trouxe uma lembrança para você.

Ele pegou sem jeito no embrulho, rasgou o papel e segurou o livro na mão, sorrindo ao título. Era a autobiografia de Vilém Flusser, que eu devorara no 
último mês por conta da sua recomendação. Não, ele não tinha o livro; ficou tão desconcertado, sem saber como reagir, que pousei uma mão no seu ombro e desconversei, dizendo que ele me devia um café um dia desses.

Russo começou a engatar um monólogo sobre a fuga de Flusser de Praga para Inglaterra e depois Brasil, emendando rapidamente a ideia de imigrantes como vanguarda, o desabamento do universo com que o desenraizado se depara, o tremor da estrutura da realidade quando os acontecimentos - como os da guerra são impossíveis de serem abarcados em seu terror pela linguagem. Folheando o livro, tirou a caneta do bolso da bermuda, e começou a sublinhar, em linhas rápidas e tortas, trechos e trechos, que lia em voz alta, quer dizer, num murmúrio enrolado ainda mais pela voz pastosa dos ansiolíticos, certamente.

Pois tudo desapareceu. Não "de golpe" (como gostavam de dizer os nazistas) mas aos pedaços. Não com o aparecimento dos tanques nas ruas, e das inscrições góticas "em Praga se circula pela esquerda". Mas a realidade caía aos pedaços, e aos pedaços ficou engolida pelo abismo. Veio a manchete "Finis Austriae" no Prager Tagblatt. Como digerir isto? Digerir que os parentes de Viena, da cidade-irmã, eram sistematicamente assassinados? Os refugiados contavam os acontecimentos, mas estes continuavam incríveis. (...) Pesadelos invadiam a realidade. Não se sabia mais distinguir entre sonho e dia. Desperto. A estrutura da realidade tremia. (FLUSSER, 2007, p. 37.)

Está vendo, aqui? Ele dizia: Flusser se perguntava se a derrocada do fundamento não passava de uma experiência subjetiva. Para ele, ter perdido a pátria, família e posição não eram suficientes para destruir o fundamento e atirar o indivíduo na liberdade vertiginosa de ser independente para recriar o próprio mundo. E quando o fundamento cede, é preciso, veja, "que se esconda o novo entusiasmo que isto cria. O entusiasmo da observação distanciada".

"É claro que isto abria os horizontes", ele continuava, lendo, "mas expandia ainda mais radicalmente a convicção de que todo provincianismo é resultado não de situação geográfica mas de enquadramento. Não importa se praguense ou londrina," (ou brasileira ou portuguesa, acrescentei mentalmente) "a gente é provinciana se tem fundamento".

Era melhor ter radares do que raízes? Para Flusser sim; para Russo aparentemente também. Não sei se concordo, comentei. É muito vertiginosa essa 
liberdade, mas e quando não se sabe o que fazer dela? É mais útil sentir-se pertencendo a algum universo, instalado na ordem do mundo, com um lugar para si próprio. Russo não concordava, e enveredou por argumentos mais teóricos que não consigo reproduzir aqui. E leu mais um trecho: "quem foi arrancado da ordem vê o mundo todo" (FLUSSER, 2007, p. 44).

Então o desenraizado, sem fundamento, o fora de lugar teria uma visão exterior vantajosa em relação àqueles submetidos - e inseridos - na ordem da normatividade. Esse olhar independente, amplo, despido de preconceitos e da cegueira imposta pelas normas é o que faz destes indivíduos a vanguarda, para Flusser. Talvez essa visão além fosse o permitiu a Rothko, Pollock, Grombowski, Sebald, Said e ao próprio Flusser, entre outros artistas imigrantes, produzirem uma arte vibrante, que rompe as estruturas, questiona a ordem - não se deixa rotular, prender, transformar em produto facilmente consumível. Talvez estar fora da ordem, como diz Flusser, force o indivíduo a descobrir uma potência interna para se exprimir criativamente de forma explosiva, inovadora. Rompendo as barreiras do preconceito, da nacionalidade, das normas criadas pelas gerações anteriores. Pode ser que estar fora de lugar propiciasse esse olhar além.

Eu tinha que ir embora; já estava há mais de meia hora sentada naquele degrau sujo da calçada e meus pais me esperavam, do outro lado da cidade, para o aniversário da minha avó. Expliquei a Russo que teria que ir agora, mas voltaria logo, e que estaria de volta, por perto. Ele parecia não me ouvir; enquanto eu falava, sublinhava um trecho do livro. Quando terminei e me levantei, ele me devolveu o volume, aberto na página sublinhada. Depois eu devolvo, é isso? Ele fez que sim com a cabeça. Levantei e voltei com a cachorra para casa, passei pela portaria até chegar no elevador e poder ler, sozinha, o trecho destacado por ele.

(...) [Nos últimos dias em Praga] veio uma sensação de todo inesperada. A sensação de liberdade vertiginosa. Doravante não se pertencia mais a ninguém nem a lugar nenhum, era-se independente. Tudo isto, a cidade e seus habitantes, os bárbaros que a ocupavam, e apropria família, não passava, de fantoches. A gente olhava isto tudo de cima. E tal visão abria horizontes de um céu infinito. Doravante tudo era possível. E para dentro de tal possibilidade sem limite a gente se precipitava, de coração sangrento, mas de espírito aberto. (FLUSSER, 2007, p. 39) 
Eu quero, quero, quero, quero,

Amanhã vou-me casar,

Já passei a roupa o ferro.

Já passei o meu vestido,

Amanhã vou-me casar, e o Manel é meu marido!

Minha avó repetia os versinhos num murmúrio, entre outros dizeres que para mim não faziam sentido. Sua voz era um chiado baixo, um ruído de corte, ecoando em círculos, indo e vindo em versos redondos como cirandas. Lallen. O som, a lenga-lenga da sua voz ocupando o silêncio das escadas da frente de casa. Vovó cantarolava versos de sua juventude, e eu gravava no telefone; as frases familiares como as de cantigas de ninar, encravadas no fundo da memória. A cada pequena estrofe mais um fragmento, um gaguejo, uma início de risada. Um impulso para o nascimento da linguagem.

Todos me querem, eu quero alguém,

Todos me querem, eu quero só um, Quero meu amor, não quero mais ninguém.

Quero meu amor, não quero mais nenhum

Lembro de Hölderlin, Celan - Pallacksch, Pallacksch -, minha avó Guida nada tem de judia, mas seu balbucio dava corpo a um vazio, a um silêncio - como resquícios de memória de um computador, resistindo contra o apagamento do sistema. Ela cantava fechando as pálpebras, como se procurando a fonte da memória dentro de si, desmembrando camadas de lembrança na repetição de cada verso. Há quanto tempo não cantava essas canções? Quanto tempo elas tinham ficado guardadas intactas ali dentro? Só sei que ela cantava e eu gravava, e, quando percebi, já cantarolava junto o refrão. Como se fosse uma colega na festa da colheita das espigas, minha avó ainda moça, a pele lisa e os cabelos trançados, as palmas das mãos grossas do trabalho no campo. Os risos e olhares dos moços escolhendo noivas para levarem para o Brasil.

E o Manel é meu marido / E o Manel quem me adora,

E o Manel é quem me leva...da minha casa para fora.

Da minha casa para fora, da minha casa para dentro 


\section{É o Manel quem me leva, no dia do Casamento!}

Noventa e dois anos, ela fazia hoje. Mais de sessenta indo e vindo pelo Atlântico. Com essa idade, já não podia viajar, por isso comemoraríamos o aniversário dela na Cadeg, num restaurante daqueles com concertina onde ela pudesse pensar, por algumas horas, que estava mais perto de casa. Como isso é triste, comentei com meu pai. Triste é ficar num asilo, ele me devolveu em segundos.

De repente olhei para a minha avó, seu rosto vincado de rugas, os olhos azulados da catarata fechando e abrindo ao ritmo da música, que ela marcava batendo palmas, as mãos se unindo em silêncio fazendo pulsar a ausência. Como se a falta, a perda fosse a função organizadora e operante de tudo - o astro em torno do qual os satélites da sua vida giram. A casa com quintal no subúrbio do Rio, onde criou filhos e netos não era a "sua"; mas a minha, onde vivo há dez anos, também não é. A casa de sua mãe, minha bisavó, lá na aldeia, hoje é um terreno dividido entre irmãos e sobrinhos onde ela é apenas uma visita. A minha casa, uma quitinete perto da praia de Oeiras, foi vendida por um terço do preço original para uma família de peruanos. No quintal dos seus irmãos minha avó ainda encontra as pereiras e macieiras da infância; eu ainda avisto de longe a varanda do primeiro andar esquerdo, numa nostalgia estúpida de um quarto e sala no qual vivia sozinha, com memórias, livros e poucos amigos. A voz da minha avó agora é um murmúrio baixinho, que resiste ao som dos mecânicos e oficinas da avenida ocupada pela milícia. Que resiste ao barulho do carro dos meus pais chegando, que continua, apesar do rádio ligado, concentrada em si mesma, atravessando espaço e tempo - alojando-se na minha memória, uma forma de insistir em existir, ressurgindo em qualquer costa. 


\section{Referências Bibliográficas}

ADICHIE, Chimamanda Ngozi. Americanah. São Paulo: Companhia das Letras, 2014.

AGAMBEN, Giorgio. O que é contemporâneo? In: $O$ que é Contemporâneo $e$ outros ensaios. Chapecó: Editora Argos, 2009.

Al BERTO. Horto de incêndio. Lisboa: Assírio \& Alvim, 1997.

ANDERSON, Benedict R. Comunidades imaginadas: reflexões sobre a origem e a difusão do nacionalismo. São Paulo: Companhia das letras, 2008.

APPADURAI, Arjun. "Notas para uma geografia pós-nacional". In: Novos Estudos Cebrap, n.49, novembro de 1997.

APPIAH, Kwane Anthony. Cosmopolitismo: A ética en um mundo de extraños. Buenos Aires; Madri: Katz, 2007.

BARRENTO. João. "Um quarto de século de poesia portuguesa". In: Semear, n. 4, Revista da Cátedra Pe Antonio Vieira de Estudos Portugueses. RJ: PUC Rio, 2000. Disponível em:

http://www.letras.puc-rio.br/unidades\&nucleos/catedra/index.html. Acesso em: março, 2017.

BARTHES, Roland. A preparação do romance: I - Da vida à obra. Notas de cursos e seminários no Collège de France, 1978-1979. Texto estabelecido e anotado por Nathalie Léger. Trad. Leyla Perrone-Moisés. São Paulo: Martins Fontes, 2005.

BARTHES, Roland. Aula. São Paulo: Martins Fontes, 1980.

BARTHES, Roland. "Durante muito tempo fui dormir cedo". In: O rumor da língua. Trad. Mário Laranjeira. São Paulo: Martins Fontes, 2004.

BENJAMIN, Walter. O Narrador: Considerações sobre a obra de Nikolai Leskov. In: Magia e Técnica, arte e política. Obras escolhidas, vol. I. São Paulo: Brasiliense: 1993.

Brasiliense, 1994.

Charles Baudelaire: um lírico no auge do capitalismo. São Paulo:

BHABHA, Hommi. O local da cultura. Belo Horizonte: editora UFMG, 1998.

BIRMAN, Daniela. Fúria e Exílio. Sobre Salman Rushdie e outros imigrantes. Revista Garrafa, v. 1, p. 3, 2003.

CALVINO, Ítalo. Cidades Invisíveis. São Paulo: Companhia das Letras, 1990. 
CARDOSO. Dulce Maria. O retorno. Lisboa: Tinta da China, 2013.

CARUTH, Cathy. (1995). Trauma. Explorations in memory. Baltimore/Londres: John Hopkins University Press.

DELEUZE, Gilles; Guattari, Felix: Mil Platôs vol I. São Paulo, Ed. 34, 1995. Mil platôs. Vol. 5. São Paulo: Ed. 34, 1997. Rizoma. Lisboa: Assírio \& Alvim, 2006.

DELEUZE, Gilles. Kafka: para uma literatura menor. Lisboa: Assírio \& Alvim, 2002.

DERRIDA, Jacques. De l'hospitalité, Paris: Calmann-Levy, 1997.

FELMAN, Shoshana. (1991) "In an Era of Testimony: Claude Lanzmann's Shoah", Yale French Studies, No. 79 (1991), Literature and the Ethical Question.

FIGUEIREDO, Vera Lúcia Follain (s.d.p.). "Ficção e desenraizamento". In: Fórum Virtual de Literatura e Teatro. Disponível em: <http://www.pacc.ufrj.br/literatura/arquivo/polemica_ficcao_e_desenraizamento.p hp> . Acesso em: 13 dez. 2010.

FOUCAULT, Michel. Microfísica do poder: Michel Foucault. Organização e tradução de Roberto Machado. Rio de Janeiro: Graal, 1998.

Ditos \& escritos III - Estética: literatura e pintura, música e cinema. Rio de Janeiro: Forense Universitária: 2001.

FLUSSER, Vilém. The freedom of the migrant - objetions to nationalism. Translated by Kenneth Fronenberg. Illinois: University of Illinois Press, 2003.

Bodenlos. Uma autobiografia filosófica. São Paulo: Annablume, 2007.

GAGNEBIN, Jeanne-Marie. (2006). "Memória, história e testemunho". In: Lembrar, escrever, esquecer. São Paulo: Editora 34.

. "O preço de uma reconciliação extorquida". In: O que resta da ditadura: a exceção brasileira. Org. TELES, Edson; SAFATLE, Vladimir. São Paulo: Boitempo, 2010.

GILROY, Paul. Atlântico negro. São Paulo: Ed. 34, 2012.

GODINHO, Rafael. "Prefácio". In: DELEUZE, Jacques. Kafka: para uma literatura menor. Lisboa: Assírio \& Alvim, 2002.

GOMBROWICZ,Witold. Diary. London: Yale University Press, 2012. 
GOMES, Renato Cordeiro. "Cosmopolitismo em tempos midiáticos: um desafio contemporâneo". Revista Novos Olhares. V. 3, n. 2. Disponível em:

http://www.revistas.usp.br/novosolhares/article/viewFile/90196/92907.Acesso em: julho, 2015.

GUMBRECHT, Hans Ulrich. "Minimizar identidades". In: JOBIM, JL. (Org). Literatura e identidades. Rio de Janeiro: Eduerj, 1999.

HALL, Stuart. "The Spectacle of the 'Other'," in Stuart Hall (Ed.) Representations. Cultural Representations and Signifying Practices. London: Sage and The Open University, 1997.

UFMG, 2003.

HEMON, Aleksandar. As fantasias de Pronek. Rio de Janeiro: Rocco, 2009.

Amor e obstáculos. Rio de Janeiro: Rocco, 2011.

.O livro das minhas vidas. Rio de Janeiro: Rocco, 2013.

KAMENSZAIN, Tamara. O gueto e o eco de minha mãe. Rio de Janeiro: 7Letras, 2012.

O livro dos divãs. Rio de Janeiro: 7Letras, 2015.

KHAN, Sheila. "A pós-colonialidade portuguesa na emergente literatura dos retornados". In: KHAN, Sheila. Portugal a lápis-de-cor - a sul de uma póscolonialidade. Lisboa: Almedina; CES (Centro de estudos sociais / Laboratório Associado da Universidade de Coimbra), 2015.

KRISTEVA, Julia. Estrangeiros para nós. Rio de Janeiro: Rocco, 2004.

MCLENNEN, Sophia A. The Dialetics of Exile - Nation, time, Language and Space in Hispanic Literatures. Indiana: Purdue University, 2004.

MIGLIEVITCH RIBEIRO, Adélia. Intelectuais no exílio: onde é a minha casa? In. Dimensões, vol. 26, 2011, p. 152-176.

LOURENÇO, Eduardo. "Entre o ser e o silêncio (cem anos de poesia portuguesa)". In: AMARAL, Fernando Pinto do; CARVALHO, Gil de; BENTO, José; HERMÍNIO MONTEIRO, Manuel (Org).Um Século de Poesia (18881988). Lisboa: Assírio \& Alvim, 1998.

PATROCÍNIO, Paulo Roberto Tonani. Escritos à margem - a presença da periferia na cena literária brasileira. Rio de Janeiro: 7Letras, 2013. 
PIGLIA, Ricardo. "Memoria y tradición". In: CONGRESSO ABRALIC, 2, 1990, Anais... Belo Horizonte, ABRALIC, 1990. p. 60-66.

. "Una propuesta para el nuevo milenio", In: Margens/Márgenes, n. 2. Belo Horizonte, Mar Del Plata, Buenos Aires, out. 2001: 3.

PITTA, Eduardo. Um rapaz a arder. Lisboa: Quetzal, 2013.

RUSHDIE, Salman. Pátrias imaginadas. Lisboa: Dom Quixote, 1994.

Fúria. São Paulo: Companhia das Letras, 2003.

SAID, Edward W. Reflexões sobre o exílio e outros ensaios. Tradução de Pedro Maia Soares. São Paulo: Companhia das Letras, 2006.

Fora do lugar: memórias. Tradução: José Geraldo Couto. São Paulo: Companhia das Letras, 2004.

Representações do intelectual: as Conferências Reith de 1993. Tradução: Milton Hatoum. São Paulo: Companhia das Letras, 2005.

SAFLATE, Vladimir. O Circuito dos afetos. Corpos políticos, desamparo e o fim do indivíduo. São Paulo: Cosac Naif, 2015. 2 ed.

SANTIAGO, Silviano. "O entrelugar do discurso latino-americano", de 1971. In: Santiago, Silviano. Uma literatura nos trópicos. São Paulo: Perspectiva, 1978.

- Vale quanto pesa - ensaios sobre questões político-culturais. Org. Candido, Antonio. Rio de Janeiro: Paz e Terra, 1982.

O cosmopolitismo do pobre - crítica literária e crítica cultural. Belo Horizonte: Editora UFMG, 2004.

. "Ética e diversidade cultural" [Cosmopolitismo e diversidade cultural] Sabático. O Estado de São Paulo, 03/09/2011, p. 2.

SEBALD. W.G. Austerlitz. São Paulo: Companhia das Letras, 2008. Os emigrantes. São Paulo: Companhia das Letras, 2009.

Os anéis de saturno - Uma peregrinação inglesa. São Paulo: Companhia das Letras, 2010.

SELIGMANN-Silva, Marcio. O local da diferença - ensaios sobre memória, arte, literatura e tradução. São Paulo: Ed. 34, 2005.

- "Para uma filosofia do exílio: A. Rosenfeld e V. Flusser sobre as vantagens de não se ter uma Pátria." In: Revista Eletrônica do NIEJ/UFRJ -Ano I $-\mathrm{n}^{\mathrm{o}} 3$ - 2010a. 
. "Vilém Flusser: filosofia do exílio e leitura de um país chamado Brasil." Tradução em Revista, 2010b/02, p. 01-19, Puc-rio.

SPIVAK, Gayiatri. Pode o subalterno falar? Belo Horizonte: Editora UFMG, 2014.

SULEIMAN, Susan Rubin (Org). Exile and creativity: signposts, travellers, outsiders, backwards glances. Durham: Duke University Press, 1998.

TODOROV, Tzvetan. L'homme depaysé. Paris: Seuil, 1996.

WAHEE, Nayyirah. Salt. 2013.

ZAMBRA, Alejandro. Bonsai. São Paulo: Cosac Naif, 2012.

Alejandro. A vida privada das árvores. São Paulo: Cosac Naif, 2013.

Alejandro. Formas de voltar para casa. São Paulo: Cosac Naif, 2014.

\section{Vídeos:}

COHEN-SOLAL, Annie. A conversation on Mark Rothko. The Grace Rainey Rogers Auditorium at The Metropolitan Museum of Art. March 11, 2015. Disponível em: https://www.youtube.com/watch?v=_whSRF97Xsg. Acesso em: março, 2017. 